\title{
Immunosuppressive Mechanisms of Regulatory B Cells
}

\author{
Diego Catalán ${ }^{1,2 \star}$, Miguel Andrés Mansilla ${ }^{1}$, Ashley Ferrier ${ }^{1,2}$, Lilian Soto ${ }^{1,3}$, \\ Kristine Oleinika ${ }^{4}$, Juan Carlos Aguillón ${ }^{1}$ and Octavio Aravena ${ }^{1}$ \\ ${ }^{1}$ Programa Disciplinario de Inmunología, Facultad de Medicina, Instituto de Ciencias Biomédicas (ICBM), Universidad de \\ Chile, Santiago, Chile, ${ }^{2}$ Instituto Milenio en Inmunología e Inmunoterapia, Santiago, Chile, ${ }^{3}$ Unidad de Dolor, Hospital Clínico, \\ Universidad de Chile (HCUCH), Santiago, Chile, ${ }^{4}$ Faculty of Medicine, Riga Stradins University, Riga, Latvia
}

OPEN ACCESS

Edited by:

Rachel R. Caspi,

National Institutes of Health $(\mathrm{NIH})$,

United States

Reviewed by:

Arya Biragyn,

National Institutes of Health $(\mathrm{NIH})$,

United States

Charles E. Egwuagu,

National Eye Institute (NEI),

United States

*Correspondence:

Diego Catalán

dfcatalan@med.uchile.c

Specialty section:

This article was submitted to

Immunological Tolerance and

Regulation,

a section of the journal

Frontiers in Immunology

Received: 29 September 2020

Accepted: 19 February 2021

Published: 29 April 2021

Citation:

Catalán D, Mansilla MA, Ferrier A

Soto L, Oleinika K, Aguillón JC and

Aravena O (2021) Immunosuppressive Mechanisms of Regulatory B Cells.

Front. Immunol. 12:611795.

doi: 10.3389/fimmu.2021.611795
Regulatory B cells (Bregs) is a term that encompasses all B cells that act to suppress immune responses. Bregs contribute to the maintenance of tolerance, limiting ongoing immune responses and reestablishing immune homeostasis. The important role of Bregs in restraining the pathology associated with exacerbated inflammatory responses in autoimmunity and graft rejection has been consistently demonstrated, while more recent studies have suggested a role for this population in other immune-related conditions, such as infections, allergy, cancer, and chronic metabolic diseases. Initial studies identified IL-10 as the hallmark of Breg function; nevertheless, the past decade has seen the discovery of other molecules utilized by human and murine B cells to regulate immune responses. This new arsenal includes other anti-inflammatory cytokines such IL-35 and TGF- $\beta$, as well as cell surface proteins like CD1d and PD-L1. In this review, we examine the main suppressive mechanisms employed by these novel Breg populations. We also discuss recent evidence that helps to unravel previously unknown aspects of the phenotype, development, activation, and function of IL-10-producing Bregs, incorporating an overview on those questions that remain obscure.

Keywords: regulatory B cells, IL-10, TGF- $\beta$, IL-35, TIM-1, PD-L1, granzyme B, CD1d

\section{INTRODUCTION}

Over the last two decades, the role of regulatory B cells (Bregs) in immunosuppressive responses has been documented in different contexts and diseases (1). It has been shown, for instance, that Bregs can suppress animal models of autoimmunity, such as experimental autoimmune encephalomyelitis (EAE) (2), collagen-induced arthritis (CIA) (3), and spontaneous colitis (4). Bregs have also been proved to modulate allergy (5), transplantation (6), cancer (7), infections (8), and chronic metabolic diseases (9). Initial studies in the early 2000s attributed this immunomodulation to IL-10, which became the hallmark of Breg suppression $(4,10,11)$; however, this notion has lately expanded as new Breg-derived suppressive mediators have been discovered. This review offers to the reader an updated outlook on the immunosuppressive mechanisms employed by Bregs. However, before focusing on the regulatory functions, we will address some concepts with respect to the phenotypic characterization and differentiation of Bregs that still spark some controversy in the scientific community, using IL-10-producing Bregs as a prototypic example. 


\section{THE DIVERSIFICATION OF BREG PHENOTYPES}

Despite extensive efforts to phenotypically characterize Bregs, including transcriptome analyses and multiparametric flow cytometry, which have been mostly focused on IL-10-secreting B cells, we still lack a definitive set of phenotypic markers or a signature transcriptional regulator (equivalent to FoxP3 in regulatory $\mathrm{T}$ cells- Tregs) that enables us to comprehensibly identify Bregs (12-19). This has been further complicated by the large heterogeneity of factors described to induce Bregs in vivo. Surface markers such as CD9 (13, 20-22) and TIM$1(23,24)$ have been found to be predominantly but not exclusively expressed across IL-10 ${ }^{+} \mathrm{B}$ cell populations. Therefore, Bregs remain a functionally defined population based on their capacity to suppress pro-inflammatory responses in vitro or in vivo, as opposed to effector B cells, which produce proinflammatory molecules or induce other cells to do it. According to this consensus, different groups have identified phenotypically distinct B cell populations that, under specific stimulatory conditions, exhibit a superior regulatory proficiency. Many of these populations correspond to discrete developmental stages of the B cell lineage and are enriched in, but not exclusively composed of, cells expressing immunomodulatory factors, such as IL-10.

Mauri and colleagues identified a subset of IL-10-producing $\mathrm{B}$ cells with in vitro and in vivo regulatory capacities among splenic $\mathrm{CD} 21^{\mathrm{hi}} \mathrm{CD} 23{ }^{\mathrm{hi}} \mathrm{CD} 24^{\mathrm{hi}} \mathrm{CD} 1 \mathrm{~d}^{\text {hi }}$ transitional 2-marginal zone precursors (T2-MZP) in mouse (25). Transitional B cells correspond to an intermediate stage between immature cells emerging from the bone marrow and mature cells in the periphery and can be divided into T1, T2, and T3 subpopulations as they progress in their maturation. T2MZP are T2-stage progenitors committed to differentiate into marginal zone (MZ) B cells in the spleen. Human circulating $\mathrm{CD} 24^{\text {hi }} \mathrm{CD} 38^{\text {hi }}$ T2 transitional B cells have also been described to be enriched in IL-10-producing $B$ cells and are able to suppress $\mathrm{T}$ cell responses (26). More recently, it has been proposed that other subsets of human transitional B cells, namely, $\mathrm{CD} 24^{\text {hi }} \mathrm{CD} 38^{\mathrm{hi}} \mathrm{CD} 27^{+}$activated memory-like transitional cells, as well as $\mathrm{CD} 24^{\mathrm{hi}} \mathrm{CD} 38^{\text {hi }} \mathrm{IgM}^{\mathrm{lo}} \mathrm{IgD}{ }^{\text {lo }}$ anergic-like T3 transitional $\mathrm{B}$ cells, also exhibit regulatory properties (27). In addition, murine mature MZ B cells, which lack CD23 expression but maintain high levels of CD1d, have been shown to produce high levels of IL-10 and exert suppressive functions (28).

In parallel, Tedder and colleagues identified a population of murine B cells that express IL-10 after ex vivo stimulation with lipopolysaccharide (LPS) plus phorbol 12-myristate 13-acetate (PMA) and ionomycin $(\mathrm{P}+\mathrm{I})$; such $\mathrm{IL}-10^{+}$cells are enriched among $\mathrm{CD} 1 \mathrm{~d}^{\text {hi }} \mathrm{CD} 5^{+} \mathrm{B}$ cells in the spleen. They termed these cells B10 (29). The human counterpart of B10 was later found to be increased within the $\mathrm{CD} 24^{\text {hi }} \mathrm{CD} 27^{+}$memory $\mathrm{B}$ cell population (30). They proposed that B10 originate from progenitors (B10pro cells) that acquire IL-10-producing competence after stimulation of CD40 or Toll-like receptor (TLR)-4 and have been extensively proven to ameliorate an array of inflammatory conditions upon adoptive transfer (31-37). B10 and B10pro were later found in other B cell compartments, such as murine B-1a cells (31). The B-1 lineage of $\mathrm{B}$ cells reside primarily in the peritoneal cavity and spleen and are classified in B1-a and B1-b cells according to the expression of CD5 (38). Peritoneal cavity $\mathrm{CD}^{+} \mathrm{B}-1 \mathrm{a}$ cells are able to secrete high amounts of IL-10 after TLR or CD40 activation and to suppress $\mathrm{T}$ cell responses (39-43). Peritoneal cavity and spleen B10 are likely to derive from both the fetal liver and adult bone marrow compartments (42). IL-10 ${ }^{+}$Bregs can already be found among $\mathrm{CD} 1 \mathrm{~d}^{\mathrm{lo}} \mathrm{CD} 5^{+}$neonatal splenic B cells $(31,44)$. In addition, a newly identified population of human cord blood CD5 ${ }^{\text {hi }}$ cells was found to secrete IL-10 upon infection by the respiratory syncytial virus (RSV), leading to inhibition of anti-viral responses and a worse clinical outcome (45). MZ B cells and B1 cells are regarded as innate-like B cells, given their capacity to rapidly respond to innate signals, such as TLR ligands, by producing low-affinity polyreactive natural $\operatorname{IgM}$ antibodies and cytokines. Consequently, some authors have denominated those first-line IL-10-producing B cells as innate Bregs; however, the functional implications of this initial regulatory response has not been fully understood $(46,47)$.

Recently, IL-10 ${ }^{+}$Breg populations have been described among antibody-secreting cells (ASC), such as plasmablasts and terminally differentiated plasma cells, including those populating the bone marrow, in both mice and humans (15, 16, 4853). Besides, plasma cells expressing other regulatory molecules have also been described, such as IL-35-expressing CD138 ${ }^{+}$ plasma cells and PD-L1/PD-L2-expressing IgA ${ }^{+}$plasma cells $(16,54)$. These regulatory ASCs are capable of modulating immune responses, as shown in EAE and Salmonella infection models $(15,49,51,55)$. It has been observed that murine IL$10^{+} \mathrm{B}$ cells have a greater potential to rapidly differentiate into ASCs than $\mathrm{IL}_{-} 10^{-} \mathrm{B}$ cells, as determined by their upregulation of the ASC fate-determining molecule Blimp-1 and the production of IgM (56). Furthermore, studies in IL10 -reporter mice showed that IL- $10^{+}$ASCs are already found in naïve mice, while LPS administration or infection with Salmonella rapidly expands ASCs that transiently upregulate IL-10 production $(15,43,49,56)$. Subsequent findings in the Salmonella infection model showed that in CD138 ${ }^{\text {hi }}$ plasma cells, the il10 locus was already primed for transcription (15). Transcriptional analyses of human activated IL- $10^{+}$B cells have found, as for mouse, the upregulation of genes coding for molecules involved in plasma cell differentiation, such as Blimp-1 and IRF4, thus confirming that human IL- $10^{+} \mathrm{B}$ cells are also capable of becoming ASCs (12, 17, 19, 57). Interestingly, it has been suggested that human and mouse IL10-producing ASCs can be differentiated directly from immature and naïve $B$ cells $(15,55)$, which is supported by the finding that Blimp-1 is already expressed in recently activated naïve B cells $(58,59)$.

Altogether, the phenotypical diversity of Bregs suggests that, in addition to classical fate-determining programs, any $B$ cell, regardless of its developmental stage or tissue residence, holds the potential to engage a regulatory program, determined by one or more yet-to-be-identified master transcriptional factors and finely regulated by environmental conditions. 


\section{BREG DIFFERENTIATION: NURTURE OR NATURE?}

B cell regulatory capacity can be triggered by inflammatory cues, such as TLR ligands and pro-inflammatory cytokines, by upregulating a set of inhibitory molecules that restrict the extent of inflammation (20). This idea is supported by findings revealing that T2-MZP IL- $10^{+}$Breg differentiation can be driven by IL- $1 \beta$ and IL- 6 , together with CD40 stimulation, in the context of inflammatory arthritis (21). Other pro-inflammatory cytokines involved in Breg induction are B cell-activating factor (BAFF) and A proliferation-inducing ligand (APRIL). BAFF and APRIL are mainly produced by myeloid cells and increased upon inflammation. They participate in B cell homeostasis at different developmental stages, from transitional cell maturation to plasma cell survival. Mice overexpressing BAFF develop spontaneous autoimmunity and increased levels of BAFF have been detected in patients with autoimmune conditions (22). Nevertheless, BAFF and APRIL have been shown to also enhance IL-10 ${ }^{+}$and IL- $35^{+}$ Bregs in mice and humans $(23,24,51,60-64)$.

A regulatory feedback loop has been demonstrated between plasmacytoid dendritic cells (pDCs) and B cells in humans and mice, whereby $\mathrm{pDCs}$ respond to inflammation by secreting interferon (IFN)- $\alpha$, enhancing the production of IL-10 by activated B cells, which in turn suppresses IFN- $\alpha$ production by pDCs $(44,65)$. Noteworthy, this circuit is impaired in systemic lupus erythematous (SLE), a disease characterized by an IFN$\alpha$ signature that contributes to pathogenesis by stimulating the differentiation of autoantibody-producing plasma cells. Interestingly, high concentrations of IFN- $\alpha$ in the presence of a TLR9 agonist in vitro lead to the differentiation of IL-10 ${ }^{-}$plasma cells instead of IL-10 ${ }^{+}$Bregs $(65,66)$.

IL-21, together with CD40 ligand (CD40L) and/or TLR9 signals, has been described to boost B10 generation or to drive the emergence of $\mathrm{IL}-10^{+}$plasmablasts during inflammatory processes (53, 67-70). IL-21 and CD40L are expressed by follicular helper $\mathrm{T}$ cells (Tfh) in the germinal center (GC), enabling $\mathrm{B}$ cells to express affinity mature class-switched antibodies and to become memory B cells or long-lived plasma cells (71). Thus, it is possible that during GC reactions, both effector and suppressive memory B cells and plasma cells are generated. Altogether, these results suggest that during an acute immune response, the generation of effector B cells and Bregs is balanced; however, when inflammation turns chronic, this equilibrium may be lost.

Inflammation-induced IL- $10^{+}$Bregs employ molecules involved in both mounting and constraining immune responses. CD80 and CD86 are co-stimulatory ligands that enable professional antigen-presenting cells (APCs) to deliver either activating or inhibiting signals to $\mathrm{T}$ cells upon binding to CD28 or CTLA-4, respectively (72). Memory and GC B cells exhibit constitutive expression of CD80 and CD86, which can be upregulated following activation. Antigen presentation by $B$ cells has been demonstrated to be required for optimal effector immune responses (73-77). On the other hand, antigen presentation by $\mathrm{B}$ cells that lack CD80/CD86 can induce $\mathrm{T}$ cell anergy or Tregs $(78,79)$. Pioneering studies showed that
CD86 is involved in B cell suppression of pathogenic T cells and in preventing disease development in a murine model of colitis $(80,81)$. Similarly, MHC II molecules appear to be necessary for the establishment of cognate interactions between Bregs and activated $\mathrm{T}$ cells $(57,70)$. These results were further confirmed for human IL-10 ${ }^{+}$Bregs, in which CD80 and CD86 work synergistically with IL-10 to suppress Th1 responses $(26,82)$. Studies in humans and mice have demonstrated that the interaction of CD80/CD86 with CD28 is required for peripheral homeostasis of Tregs, while their engagement of CTLA-4 is important for Treg-mediated suppression (83-85). It was later observed that CD80/CD86-deficient B cells were unable to induce Tregs (81). Although a high expression of CD86 and CD80 have been described in murine and human Breg populations, it appears that their sole upregulation does not enable for a comprehensive identification of Bregs, while a correlation between high expression and functional relevance remains to be fully elucidated (86-88). Therefore, it appears that CD80/CD86 do not constitute a suppressive mechanism by themselves, but instead allow B cells with regulatory capacity to establish cognate interactions with activated $\mathrm{T}$ cells to inhibit them or convert them to Tregs.

The fact that, in many cases, similar conditions can induce the differentiation of effector $\mathrm{B}$ cells and $\mathrm{IL}-10^{+}$Bregs gives rise to the question of how this fate decision is made. Are some B cells imprinted, at some point during their ontogeny, with the potential to produce IL-10 upon an inflammatory challenge or is the fate of a particular B cell dependent on autonomous perception of spatiotemporal and environmental cues? Is it a stochastic event or is it commanded within narrow ranges of concentration, duration, combination, and concatenation of the stimuli? Is the regulatory phenotype a transient state of B cells, which would die immediately after, or even revert to an effector phenotype if the inflammation persists, or is it a stable trait? Transcriptomic analysis of B cells isolated from arthritic mice showed that the expression of pro-inflammatory cytokines is not substantially different between total IL- $10^{+}$and IL- $10^{-}$B cells (14). Lately, a characterization of CpG-stimulated human B cells found that most IL- $10^{+} \mathrm{B}$ cells co-express TNF and IL- 6 across a broad range of phenotypes. When purified, $\mathrm{IL}-10^{+} \mathrm{B}$ cells were re-stimulated, their capacity to produce IL-10 was lost, while IL$10^{-} \mathrm{B}$ cells were able to secrete IL-10 after a second challenge, arguing against the existence of a dedicated Breg lineage (18). IL$10^{+}$Bregs can also be generated induced by anti-inflammatory factors, such as IL-35 and retinoic acid $(89,90)$; whether these Bregs are more stable remains unclear.

\section{REGULATION OF IL-10 EXPRESSION BY B CELLS}

In order to understand better how B cells integrate the different signals that endorse them with the capacity to produce IL-10, we considered relevant to present a general overview of the intracellular pathways involved in this process.

BCR signaling appears to be fundamental for IL-10 ${ }^{+}$Breg development, as mice whose $\mathrm{B}$ cells have a transgenic BCR 
specific for an irrelevant antigen show reduced IL-10 production after ex vivo stimulation with LPS and P+I (31). In addition, in vivo studies show that suppression of inflammation upon $\mathrm{B}$ cell adoptive transfer is significantly more potent when antigenexperienced B cells compared to B cells from naïve mice or $B$ cells specific for unrelated antigens are used, suggesting that BCR engagement is important for optimal IL- $10^{+}$Breg functions $(10,25,29,70,91)$. This is further corroborated by the observed expansion or reduction of $\mathrm{IL}-10^{+}$Bregs following CD19 overexpression or deletion, respectively $(15,29,31)$. Livecell imaging of IL- $10^{+}$Bregs has recently provided evidence that these cells need to capture antigen through their BCR, in order to establish cognate interactions with antigen-specific T cells (52). IL-10-producing murine $B$ cells have shown a diverse, mainly germline-encoded, BCR repertoire, part of which is reactive to self-antigens or antigens from commensal microbes (15, 42, 51, 56). This evidence also supports the notion that Bregs could play a significant role in sensing autoantigens and/or microbiota, limiting a potentially noxious activation of immunity.

Several sources have pointed toward TLR and CD40 activation as an important step in enabling B cells to become competent IL-10 producers. Stimulation of B cells from naïve mice with LPS or CpG (a TLR9 ligand) induces a robust production of IL-10 (31, 92, 93). Moreover, B cell expression of TLR2/4 or their downstream mediator MyD88 is required for an optimal IL-10 production upon LPS stimulation and to achieve in vivo suppression by IL- $10^{+}$Bregs in the EAE and Salmonella infection models $(31,49,92)$. On the other hand, stimulation of mouse B cells with an agonistic anti-CD40 antibody in vitro and in vivo leads to an increase in IL- $10^{+}$Bregs able to suppress arthritis and lupus in murine models $(3,94)$, while B cells overexpressing CD40L exhibit higher frequencies of B10 (31). The activation of CD40 is believed to be important for IL- $10^{+}$Breg generation as part of cognate interactions with activated $\mathrm{T}$ cells, as $\mathrm{B}$ cells lacking CD40 are unable to inhibit $\mathrm{T}$ cell activation and to protect mice from EAE or colitis $(10,70,80)$. Human B cells were also shown to produce IL-10 in response to TLR ligands and CD40L (30, 55, 95). Innate immune cells, such as pDCs, mast cells, and type 3 innate lymphoid cells, can be additional sources of CD40L-derived signals (65, 96-98).

$\mathrm{B}$ cells express a large set of inhibitory receptors that deliver negative signals to counterbalance their activation. Some of these receptors have also been found to restrain IL-10 production by Bregs. CD22 is an inhibitory receptor responsible for activating phosphatases upon binding to mammalian-restricted sialylated proteins, in order to dampen BCR activation by self-antigens (99). In agreement with CD22 inhibitory function, murine B10 lacking CD22 present an increased production of IL-10 after short-term LPS stimulation (31). Likewise, a dramatic expansion of IL- $10^{+}$Bregs is observed when CD22 deletion is incorporated in CD40L-overexpressing B10 after TLR or CD40 activation, and they exhibited enhanced EAE suppressive capacity (31, 100). However, lack of CD22 impairs the survival of regulatory peritoneal B-1a cells and their recruitment to lymphoid organs (101). Much less studied is the role on B cells of CD72, a receptor for the inhibitory ligand semaphorin-4D, but that also recognizes RNA-containing self-antigens, downregulating BCR signaling (102). Cd72-/- mice display an increased number of LAG- ${ }^{+}$CD $138^{\text {hi }}$ plasma cells, which produced augmented IL-10 levels following Salmonella infection, leading to impaired control of the bacteria (15).

Although antibody-mediated crosslinking of the BCR precludes IL-10 production upon simultaneous stimulation with LPS or CD40 ligation in B cells from naïve mice $(29,31,42,94)$ or human blood $(30,103)$, Bregs from mice with induced autoimmunity are able to secrete IL-10 when challenged with cognate antigens, or BCR crosslinking antibodies, plus CD40 ligation $(3,10,25)$. It is possible to infer that a sequential integration of signals (inflammatory signals first, followed by $\mathrm{T}$ cell help in the form of CD40L and IL-21, plus repeated antigenic stimulation) can determine the acquisition of IL-10 ${ }^{+}$ Breg proficiency in vivo (32).

The PI3K-Akt pathway, downstream of BCR engagement, is critical for B10 development in mice, as well as for IL-10 production following TLR4 or CD40 stimulation, suggesting that a tonic signaling through the BCR is required for further induction of IL-10 expression by other routes (88). In accordance with this idea, perturbations in the BCR signalosome adaptor BLNK and downstream kinase Btk have been found to curb LPS-mediated activation of the transcription factor STAT3 and ensuing IL-10 production by murine B10 (104). TLR stimulation followed by BCR crosslinking has been shown to induce IL-10 expression by $\mathrm{B} 10$ from naïve mice, by the calcineurin-dependent nuclear translocation of the transcription factor NFAT, triggered by store operated $\mathrm{Ca}^{2+}$ influx (105). This emphasizes the idea that pre-sensitization of $B$ cells with innate signals is a pathway to acquire a full Breg competence. An NFAT-independent calcineurin-mediated induction of IL-10 production in TLRactivated B cells has also been described (106). Of note, it has been shown that NFAT-dependent IL-10 production in B cells involves IRF4 binding to the il10 locus, suggesting a link between the induction of IL- $10^{+}$Bregs and later development of plasma cells $(55,107)$. Recently, Blimp-1 has been described to direct the differentiation of IL- $10^{+}$plasma cells $(108,109)$; however, further research is needed to dissect the pathways leading to this particular phenotype.

As for TLR-induced signals, CD40-mediated STAT3 activation appears to be central for IL-10 expression on B cells. STAT3 phosphorylation is increased in CD40-activated transitional B cells of healthy subjects but not in those from SLE patients (26). In addition, CREB, p38 MAPK, ERK1/2, and PI3K $\delta$ have been described to be required for IL-10 upregulation following TLR and/or CD40L stimulation $(58,67,110)$. c-Maf, a wellknown transactivator of IL-10 in various cell types, has also been shown to mediate IL-10 transcription by LPS-stimulated murine B cells (111). Interestingly, c-Maf interacts with arylhydrocarbon receptor (AhR) in promoting IL-10 expression on Tr1 cells (112). Recent studies have confirmed AhR as a critical factor governing TLR and BCR-mediated IL-10 production in $\mathrm{CD} 19^{+} \mathrm{CD} 21^{\text {hi }} \mathrm{CD} 24^{\text {hi }} \mathrm{B}$ cells, while inhibiting the expression of pro-inflammatory molecules and the differentiation of GC B cells and plasma cells $(14,113)$.

AhR activation in Bregs requires increased levels of a serotonin metabolite, 5-HIAA, generated by gut commensal 
bacteria that are enriched after treatment with the short-chain fatty acid (SCFA) butyrate (113). Gut microbiota promotes the differentiation of $\mathrm{IL}-10^{+}$T2-MZP Bregs in arthritic mice by inducing IL- 6 and IL- $1 \beta$ production by gut-associated lymphoid tissue (GALT) DCs and macrophages, implying that during inflammation, T2-MZP migrate to the GALT to acquire the necessary signals to become Bregs, a process that appears to be dependent on AhR expression $(14,21)$. These results are in line with evidence showing that skewing the gut microbiota composition with oral antibiotics or probiotics can modify IL$10^{+}$Breg frequencies (114-116). Moreover, gut commensal floraspecific $\mathrm{IgA}^{+} \mathrm{IL}-10^{+}$ASC can be recruited to the brain of EAE mice and reduce disease severity (51). Although gut-associated bacteria have been reported to be dispensable for IL- $10^{+}$Breg development in naïve mice $(31,42)$, current evidence suggest that their presence might be critical for the development of both inflammation and inflammation-induced IL- $10^{+}$Bregs (21).

A direct effect of SCFA pentanoate in potentiating CpGinduced IL-10 production by B cells was reported to be dependent on the activation of p38 MAPK and the glycolytic pathway, enhancing the phosphorylation of mTOR and its downstream targets S6K and ribosomal S6 (117). An induction of IL10 by an alternative pathway involving ERK1/2 and RSK, upstream mediators of S6 phosphorylation, has been described in LPS-stimulated peritoneal B cells (118). mTOR inhibition precludes IFN- $\lambda$ and IFN- $\alpha$-induced IL-10 production in BCRactivated human B cells (119). In agreement with these results, the levels of IL-10-producing B cells are reduced in kidney transplant patients receiving inhibitors of mTOR (120). Another key regulator of the glycolytic pathway, the enzyme GSK3 $\beta$, has been described as a repressor of IL-10 synthesis in B cells by enhancing the expression of NFATc1 (121). mTOR also enhances the activation of PPAR- $\gamma$, a key transcription factor for adipogenesis and metabolic reprogramming in activated T cells (122). Remarkably, PPAR- $\gamma$-deficient B cells present a reduced IL-10 production and impaired suppressive capacities, while treatment with a PPAR- $\gamma$ agonist significantly expanded IL-10 ${ }^{+}$B cells in high fat diet-fed mice $(123,124)$. Furthermore, free fatty acid palmitate can increase survival and IL-10 synthesis by adipose tissue-resident B cells, suggesting a potential participation of lipid metabolism in Breg functions (125). Accordingly, a publication has recently described that atorvastatin, an inhibitor of cholesterol metabolism, prevents IL-10 production by CpG-activated B cells through reducing geranylgeranyl pyrophosphate-mediated activation of Akt and inhibition of GSK3 $\beta$, leading to a decreased transcription of Blimp-1 and IL-10 (58). The metabolic regulation of B cell responses is an emerging field that would offer new insights into the factors that govern the fate of activated B cells, including Bregs.

As mentioned above, inflammatory cytokines potentiate IL10 expression in B cells. For instance, IL- 6 and IL- $1 \beta$ are able to prolong the phosphorylation of NF- $\mathrm{B}$ and STAT3 achieved by CD40 ligation in mouse B cells (21). Likewise, IL-21 and APRIL increase phosphorylation of STAT3 and subsequent IL10 production by B cells $(53,60,67,68)$. It has been observed that IFN- $\alpha$ boosts TLR7/8-induced IL-10 production by human
B cells by enhancing the phosphorylation of ERK1/2 and STAT3 (66). IFN- $\alpha$-induced STAT3 phosphorylation is decreased in B cells from SLE patients and is restored upon successful B cell depletion therapy (65). Contrastingly, the role of IFN- $\gamma$ on IL$10^{+}$Bregs is still controversial $(70,126,127)$. IFN- $\gamma$ upregulates IL-10 production induced by TLR7/8 and TLR9 agonists in mouse and human $B$ cells, and this involves protein kinases p38 and JNK (118). On murine MZ B cells, IFN- $\gamma$, BCR, and TLR9 signals converge for the prolonged activation of the transcription factor CREB to induce IL-10 expression $(128,129)$. A recent publication reported that human $\mathrm{IL}-10^{+} \mathrm{B}$ cells distinctively express TNF receptor 2 (TNFR2) following TLR9 stimulation and that they respond to TNFR2 agonists by increasing their IL10 production. This gives rise to the possibility that interaction of Bregs with membrane-bound TNF on activated T cells or monocytes may influence their suppressive functions (130).

Although autocrine IL-10 appears not to be necessary for the development of B10 or IL- $10^{+}$ASCs (56), an autocrine effect on IL- $10^{+}$Breg expansion following stimulation has been suggested (131). Newly discovered IL-35 also increases IL-10 production in TLR-stimulated human and mouse B cells by triggering STAT3 activation (132). Moreover, it has been recently described that tonsil-derived mesenchymal stem cells (MSCs) are an important source of IL-35, which upon co-culture with murine B cells, promote the expansion of B10, providing further evidence for the therapeutical use of MSCs in autoimmune diseases or organ transplantation (133). Indeed, inoculation with MSCs has been described to expand IL-10 ${ }^{+}$Bregs in EAE (134), murine colitis $(135,136)$, graft vs. host disease (GVHD) $(137,138)$, and allograft transplantation (139-141).

Other cytokines and factors described as IL- $10^{+}$Breg inducers include IL-33 (142, 143), granulocyte macrophage colonystimulating factor (GM-CSF) (144), a GM-CSF/IL-15 fusokine (57), thymosin- $\alpha 1$ (145), human chorionic gonadotrophin (146148), retinoic acid (149), hypoxia-inducible factor-1 $\alpha$ (150), vitamin D3 (90), insulin-like growth factor 2 (151), and indoleamine 2,3 deoxygenase (IDO) (134). Conversely, IL-10 production by $\mathrm{B}$ cells has been determined to be repressed by several molecules such as soluble TNF $(152,153)$, transforming growth factor (TGF)- $\beta$ (70, 126, 127), IL-4 (154, 155), IL-13 (156-158), IL-17 (159), lipoxin A4 (160), prostaglandin E2 (161), and progesterone and estradiol (162), although some results are divergent, likely due to different stimulation conditions or subpopulations assessed $(163,164)$. In addition, IL-10 expression by $B$ cells can be upregulated by neurotransmitters such as dopamine (165) and norepinephrine (166), as well as NMDAreceptor antagonists (167). Despite lack of information about transcriptional repressors of IL-10, it has been reported that the transcription factor Foxd3 negatively regulates the expression of IL-10 in LPS-stimulated mouse B cells (168).

Despite extensive research into the epigenetic regulation of IL10 expression in immune cells, there is still a paucity of studies on B cells $(169,170)$. Recent work explored the DNA methylation signature of the il10 locus in B cells and defined "early" and "delayed il10 regulatory regions," which are demethylated, or accessible, in B cells that produce IL-10 after short- or long-term stimulation with LPS, respectively (171). These results are even 
more meaningful considering that the "delayed il10 regulatory region" is a binding site for IRF4 in IL- $10^{+}$plasmablasts, where it might interact with NFATc1 to promote IL-10 expression (55).

Chromatin accessibility analysis of murine IL$10^{+} \mathrm{CD} 21^{\text {hi }} \mathrm{CD} 24^{\text {hi }} \mathrm{B}$ cells has shown open chromatin regions in the illo locus, as expected, but also in the Ahr locus, indicating an active transcription of this key factor (14). Of note, butyrate supplementation, which activates AhR in such CD2 $21^{\text {hi }} \mathrm{CD} 24^{\text {hi }}$ $\mathrm{B}$ cells, increases accessibility at binding motifs for partner transcription factors of $\mathrm{AhR}$, which can be attributed to butyrate activity as histone deacetylase inhibitor, as has been shown for Tregs and total B cells $(113,172)$. A short isoform of NFATc1, NFATc $1 / \alpha A$, has been shown to repress IL-10 transcription in B cells, in part by binding to the histone deacetylase HDAC1 upon BCR or TLR activation $(173,174)$. TNF and IL-13 repression of IL-10 production by human B cells can be partially mediated by enhancing HDAC11 expression $(153,156)$. Histone acetylation, a critical mechanism in increasing chromatin accessibility, is read by BET proteins, which facilitate chromatin remodeling (175). Although this territory remains largely unexplored in Bregs, it was recently reported that BRD4 BET enhances IL-10 expression in LPS-stimulated murine B cells by associating with NF- $\kappa \mathrm{B}$ on the il10 promoter (176).

Finally, the regulation of IL-10 expression by small, conserved, non-coding RNA-microRNA (miRNA)-has been evaluated in recent years. Initial transcriptomic studies found 77 differentially expressed miRNAs in mouse B10 compared to non-B10, the impact of which has not yet been explored (13). However, the function of a handful of miRNAs in modulating IL-10 transcription in mouse and human B cells has been described, many of which are responsive to pro- and anti-inflammatory cytokines and have been found to be dysregulated in a variety of immune-related disorders (154, 155, 157-159, 177-189). Many other signaling molecules, as well as epigenetic and posttranscriptional regulators of IL-10 expression in B cells, have been proposed; however, a definite transcriptional program remains obscure (170).

\section{SUPPRESSIVE MECHANISMS OF BREGS BY SOLUBLE MOLECULES}

The ability of B cells to secrete immunomodulatory molecules has gained increasing attention over the last years. Although many Breg functions can be attributed to the release of antiinflammatory cytokines, other soluble molecules have been recently described to mediate B cell suppression, such as granzyme B (GrB) (190), adenosine (191-193), IDO (194), progesterone-induced blocking factor 1 (195), and heat shock protein-70 (196). The main suppressive mechanisms employed by Bregs through the secretion of soluble molecules are summarized in Figure 1.

\section{IL-10}

In vitro and in vivo adoptive transfer experiments initially showed that different populations of murine-activated B cells are able to suppress antigen-specific $\mathrm{CD} 4^{+} \mathrm{T}$ cell proliferation and pro-inflammatory cytokine production in an IL-10-dependent manner and reduce inflammation in autoimmunity models, such as $\operatorname{CIA}(3,23,25,36,197)$, antigen-induced arthritis (11, 14, 21, 113), spontaneous lupus (94), type 1 diabetes (198), colitis (42), and $\operatorname{EAE}(10,57,70,105,199)$. IL- $10^{+} \mathrm{B}$ cells and plasma cells have been found to gain access to the central nervous system and suppress pathogenic $\mathrm{CD}^{+} \mathrm{T}$ cells, demonstrating their ability to act in situ $(51,200,201)$. The inhibition of $\mathrm{T}$ cell proliferation and production of Th1 cytokines (IFN- $\gamma$ and TNF) was also demonstrated in in vitro studies involving human B10 and IL- $10^{+}$transitional B cells; however, B cells from patients with autoimmune diseases such as SLE, RA, and type 1 diabetes are unable to achieve this suppression $(26,30$, $67,95,202,203)$. Moreover, immunocompromised humans or mice with Wiskott-Aldrich syndrome protein deficiency (204206), as well as patients with common variable immunodeficiency $(207,208)$ exhibit low numbers of $\mathrm{IL}-10^{+} \mathrm{B}$ cells that correlate with increased pro-inflammatory $\mathrm{CD}^{+}{ }^{+} \mathrm{T}$ cell responses. As $\mathrm{T}$ cells express low levels of IL-10R, it has been suggested that the $\mathrm{CD}^{+}{ }^{+} \mathrm{T}$ cell suppression relies on an autocrine effect of IL-10, decreasing CD86 expression and co-stimulation potential of B cells $(209,210)$. Murine and human Bregs can also act on naïve $\mathrm{CD}^{+}{ }^{+} \mathrm{T}$ cells, blocking their differentiation into Th17 cells, a feature important for recovery from CIA. This pathway is also defective in RA patients $(36,211)$.

Pro-inflammatory $\mathrm{CD}^{+} \mathrm{T}$ cell responses are a critical driving force of chronic cardiovascular diseases (212). In the spleen of atherosclerosis-prone mice, increased IL- $10^{+}$B cells have been detected. These B cells were able to suppress Th1 responses in vitro in an IL-10-mediated fashion (213). In a model of arterial injury, a high number of IL- $10^{+}$ T2-MZP were found in lymph nodes and, upon adoptive transfer, were able to reduce atherosclerotic lesions (9). IL$10^{+}$Breg-mediated atheroprotection has been suggested to be dependent on angiotensin II signaling in B cells (214), L-selectin expression (215), and IDO activation (216). IL$10^{+} \mathrm{B}$ cells have also been recovered from tertiary lymphoid organs in arteries of atherosclerotic mice, suggesting that in atherosclerosis (like in neuroinflammation), Bregs may also suppress inflammation in situ (217). In addition, scattered publications have reported reduced levels of transitional or IL- $10^{+} \mathrm{B}$ cells in peripheral blood of atherosclerotic patients compared to healthy controls $(154,178,218,219)$. Furthermore, there is accumulating evidence pointing toward a protective role of IL-10-producing B cells in controlling inflammation and tissue damage following experimental ischemic stroke (220225). A recent study exploring the involvement of IL-10producing $\mathrm{B}$ cells in myocardial infarction in rodents observed that these cells are recruited to the infarcted heart from pericardial adipose tissue and contribute to limit the extent of inflammation-related injury (226). In this regard, IL-10producing $\mathrm{B}$ cells have been found to reside in subcutaneous and visceral adipose tissues from mice and humans; in dietinduced obesity models, they contribute to the restriction of local inflammation and thereby control insulin resistance (125, 227, 228). Furthermore, adipose tissue or peripheral blood IL$10^{+} \mathrm{B}$ cells are numerically and functionally altered in both 


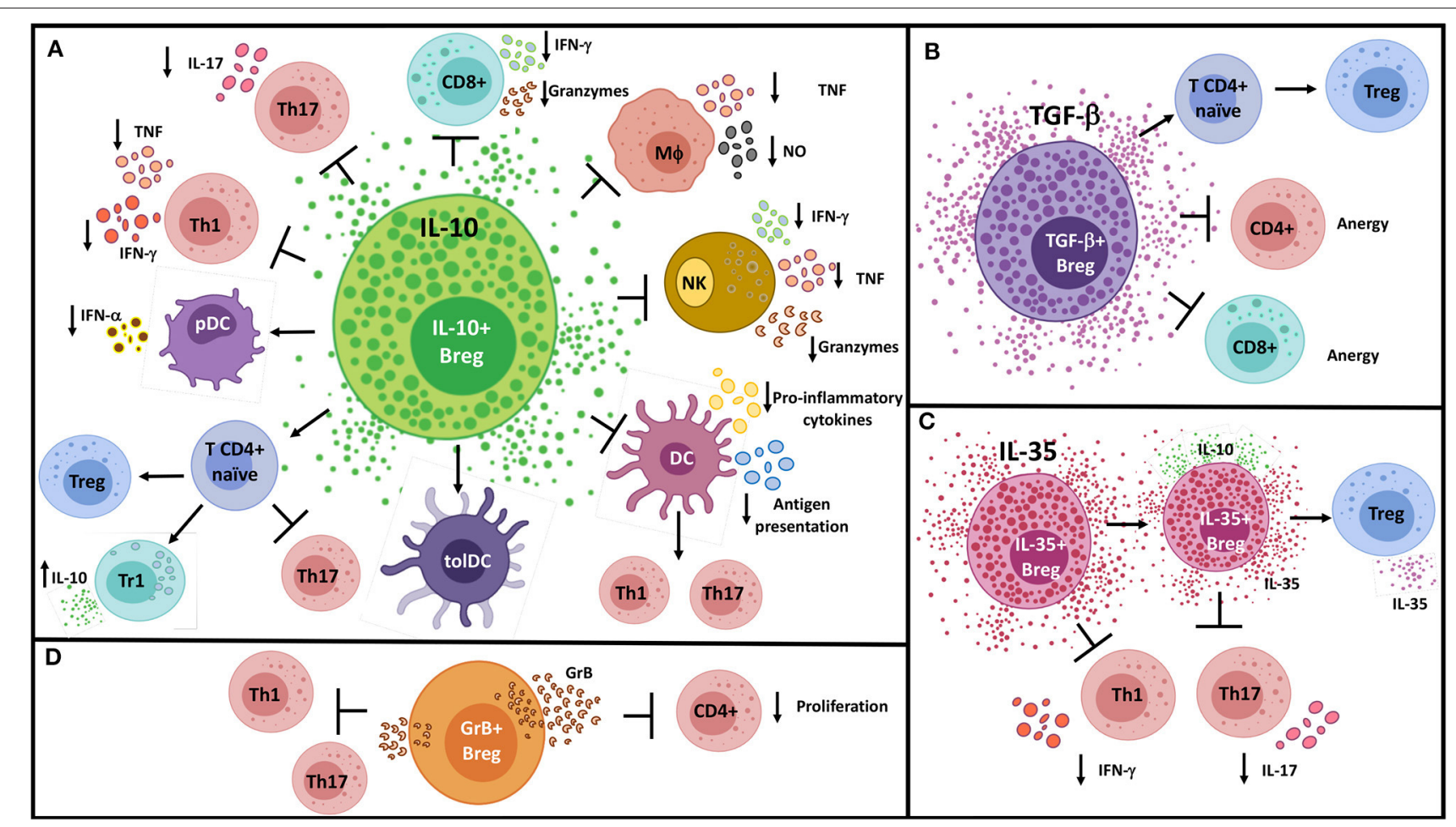

FIGURE 1 | Suppressive mechanisms of Bregs by soluble molecules. (A) IL-10+ Bregs inhibit Th1, Th17, and CD8 ${ }^{+} \mathrm{T}$ cell responses; convert naïve CD4+ $\mathrm{T}$ cells into regulatory T cell populations; and modulate pro-inflammatory innate cells through the production of IL-10. (B) Likewise, TGF- $\beta^{+}$Bregs operate on naiive CD4 ${ }^{+} T$ cells to generate FoxP3 ${ }^{+}$Tregs, in addition to induce anergy in $\mathrm{CD}^{+}$and CD8 ${ }^{+} \mathrm{T}$ cells. (C) IL-35+ Bregs can promote "infectious tolerance" by inducing IL-35-producing Tregs and expanding the generation of IL-35+ Bregs. (D) GrB ${ }^{+} \mathrm{B}$ cells have been shown to inhibit Th1 and Th17 cell responses and to reduce CD4 ${ }^{+} \mathrm{T}$ cell proliferation by degrading the TCR $\zeta$-chain. DC, Conventional dendritic cell; GrB, Granzyme B; M $\Phi$, Macrophage; NK, Natural killer cell; NO, Nitric oxide; pDC,

Plasmacytoid dendritic cell; TolDC, Tolerogenic dendritic cell; Tr1, Type-1 regulatory T cell.

obese patients and individuals with type 2 diabetes $(229-$ 234).

In addition to inhibiting immunogenic $\mathrm{CD} 4^{+} \mathrm{T}$ cell populations, $\mathrm{IL}-10^{+}$Bregs are also able to convert naïve $\mathrm{CD} 4^{+}$ $\mathrm{T}$ cells into Tregs and IL-10-secreting type- 1 regulatory $\mathrm{CD} 4^{+}$ $\mathrm{T}$ cells $(\operatorname{Tr} 1)$, as shown in experimental arthritis $(11,14,197)$, lupus $(34,94)$, and $\operatorname{EAE}(104,235)$. In agreement with this evidence, human IL- $10^{+}$Bregs from healthy individuals have been shown to induce Tregs and $\operatorname{Tr} 1$ cells; these mechanisms are impaired in autoimmune patients $(211,236,237)$, but enhanced in chronically virus-infected patients (238).

IL- $10^{+}$Bregs promoting a shift toward a Th2 response has been demonstrated to be beneficial in $\operatorname{EAE}(115,239-$ 241), CIA (25), and lupus (94). IL- $10^{+}$Bregs have also been shown to confer susceptibility or protection to parasite-derived immunopathology in mice, depending on the pathogen, partially due to their ability to skew the immune response in favor of Th2 immunity (242-246). An expansion of IL- $10^{+}$Bregs has been detected in patients with parasite infections $(247,248)$. Moreover, parasite-induced IL- $10^{+}$Bregs have been suggested to alter the course of multiple sclerosis (MS) in humans (249) and to alleviate disease in allergy models (250-254). Remarkably, allergen-specific oral tolerance induction in mice was associated with increased frequency of IL- $10^{+}$Bregs in mesenteric lymph nodes (255), and allergen specific immunotherapy drove an increase in IL-10-producing B cells in allergic patients (17, $256,257)$. These findings are validated by studies showing that adoptive transfer of IL- $10^{+}$B cells or plasma cells not only suppresses Th2 and/or Th17 responses but also induces Tregs, in allergic airway inflammation $(247,251,254,258-261)$ and food allergy (255).

The induction of tolerance to exogenous antigens by IL$10^{+}$Bregs has been further explored in the field of allograft transplantation. Studies in a model of hematopoietic stem cell transplantation (HSCT) demonstrated that both donor and host IL-10-producing B cells are required to prevent acute and chronic GVHD, in part due to the suppression of $\mathrm{T}$ cell cytokine production and induction of Tregs $(37,116,262-264)$. Similarly, a protective role of IL- $10^{+}$Bregs in human GVHD has been suggested after higher frequencies of these cells were found reconstituting recipients of HSCT who developed tolerance, compared to those who developed GVHD (53, 138, 265, 266). Analogous evidence has been obtained from solid organ transplantation models. Transitional splenic B cells prolonged skin allografts upon adoptive transfer and suppressed allospecific $\mathrm{CD}^{+} \mathrm{T}$ cells in vitro; this effect was dependent on IL10 and galectin-1 expression in donor B cells $(114,267)$. IL10 production is critical for T2-MZP-mediated cardiac allograft 
tolerance by downmodulating Th17 responses $(268,269)$. In the clinical field, several studies have pointed out that low numbers or impaired suppressive functions of transitional B cells are associated with a higher risk of kidney graft rejection (270-272). In addition, IL-10 ${ }^{+} \mathrm{B}$ cells have been shown to be increased in patients tolerating lung transplants compared to patients developing chronic graft dysfunction (273). Another study observed that the $\mathrm{IL}-10^{+} / \mathrm{TNF}^{+}$ratio in $\mathrm{T} 1$ transitional $\mathrm{B}$ cells was lower in patients rejecting kidney grafts compared to patients with stable graft function, and predicted a worse longterm outcome $(274,275)$. A number of studies have also shown increased circulating transitional B cells in tolerant kidneytransplanted patients despite withdrawing immunosuppression, compared to patients with stable grafts on immunosuppression (276-279). This high B cell-derived IL-10 expression was later associated with a decreased expression of CD86 and an increased CD40 activation by recipient T cells $(209,280)$. Besides allograft tolerance, mounting evidence implicates $\mathrm{IL}-10^{+} \mathrm{B}$ cells in mechanisms governing tolerance to semi-allogeneic fetus during pregnancy in both mouse $(147,281-285)$ and human $(146,147$, 286-289), which include the generation of tolerogenic DCs and Tregs and a reduction in Th17 cells $(281,282,290)$.

In addition to their effects on $\mathrm{CD} 4^{+} \mathrm{T}$ cells, it has been demonstrated that IL- $10^{+}$Bregs inhibit antigen-specific $\mathrm{CD} 8^{+}$ $\mathrm{T}$ cell activation. For instance, during murine cytomegalovirus and influenza virus infections, B cell-derived IL-10 restrains virus-specific $\mathrm{CD}^{+} \mathrm{T}$ cell responses $(43,291)$. Breg-mediated inhibition of $\mathrm{CD}^{+} \mathrm{T}$ cell proliferation and IFN- $\gamma$ production has also been demonstrated in patients infected with human immunodeficiency virus (HIV) $(292,293)$ and hepatitis B virus (294) and in a humanized murine model of hepatitis C virus infection (295). There is evidence that Bregs can reduce $\mathrm{CD}^{+} \mathrm{T}$ cell responses indirectly through inhibition of $\mathrm{CD}^{+} \mathrm{T}$ cell help (296). Thus, the activity of $\mathrm{IL}^{-} 10^{+}$ Bregs generated during chronic viral infections can become dysregulated, impairing virus clearance. However, in other settings, such as ankylosing spondylitis and obesity, defective IL-10-mediated downregulation of $\mathrm{CD}^{+} \mathrm{T}$ cell responses by $\mathrm{B}$ cells may promote unwanted inflammation and tissue damage $(125,297)$.

Given the pleiotropic effects of IL-10 on B cells, it has been difficult to ascertain how IL- $10^{+}$Bregs modulate humoral immune responses. IL-10 is a potent survival factor for B cells, preventing GC B cell apoptosis and favoring their development into plasma cells (298-302). In vitro and in vivo studies have proposed that these actions can be provided through autocrine and paracrine IL-10 secretion (19). In addition, IL- $10^{+}$Bregs can suppress IL-10- B cell proliferation (142). Therefore, while suppressing T cell activation, B cell-derived IL-10 may support a sustained humoral response, involving their own progression toward IL- $10^{+}$ASC.

The regulation of innate elements of the immune response appears to be a fundamental feature of $\mathrm{IL}-10^{+}$Bregs. B10 were shown to inhibit TNF or nitric oxide (NO) production by monocytes, macrophages, and microglia (30, 200, 303). Besides, murine IL- $10^{+}$Bregs can prevent the recruitment of neutrophils to the sites of inflammation in a model of colitis (42). Likewise, in a model of Salmonella infection, IL-10 production by B cells was essential for reducing neutrophil mobilization and TNF production, as well as downmodulating NK responses (49); this ultimately contributes to an impaired pathogen clearance, as has been shown for other bacterial or fungal infections $(109,304)$. B cell-derived IL-10 has also been suggested to be important in increasing the turnover of maturing neutrophils in the bone marrow following Pneumocystis infection in mice (305). Additionally, murine Breg-derived IL-10 can suppress IgEmediated degranulation of mast cells (97). As mentioned above, human and mouse IL- $10^{+}$Bregs are potent inhibitors of cytokine production by pDCs, but also by conventional DCs $(44,65)$.

Since DCs are conspicuous for their capacity to bridge innate and adaptive immune responses by priming antigenspecific naïve $\mathrm{T}$ cells, it has been evaluated whether IL- $10^{+}$ Breg suppression of $\mathrm{T}$ cell responses can be indirectly mediated through DCs. Matsushita et al. found that co-incubation of murine DCs with activated B10 reduce DCs ability to activate encephalitogenic $\mathrm{CD}^{+} \mathrm{T}$ cells (199). This evidence, together with data showing that $\mathrm{IL}-10^{+} \mathrm{B}$ cells or plasmablasts inhibit Th1 and Th17-inducing DCs or induce tolerogenic DCs, in addition to direct inhibition of Th1 and Th17 cells, contribute to clarify the suppressive role of B10 in EAE and other inflammatory conditions $(55,92,306,307)$. Similarly, B cellmediated induction of Th2 responses in Leishmania infection is associated with IL-10-dependent decrease in IL-12 production by DCs (244). Modulation of antigen presentation by IL- $10^{+}$ Bregs is also frequent during bacterial infections. For instance, Escherichia coli induces a population of IL- $10^{+}$Bregs capable of inhibiting DCs maturation (308). In experimental infection with Listeria, B10 decrease phagocytosis of bacteria and subsequent IFN- $\gamma$ and TNF secretion by macrophages, reducing antigenspecific $\mathrm{CD} 4^{+} \mathrm{T}$ cell proliferation and cytokine production (309). Another study showed that MZ B-derived IL-10 inhibits NO synthesis on neighboring metallophilic macrophages, increasing the intracellular survival of Listeria, and facilitating the transinfection of DCs, which leads to increased bacterial burden, but also to efficient $\mathrm{CD}^{+} \mathrm{T}$ cell priming (310). Interestingly, it has been shown that IL-10 ${ }^{+}$Bregs can establish longer contact times with $\mathrm{CD}^{+} \mathrm{T}$ cells than their IL-10 ${ }^{-}$counterparts (11). Based on this, a supplementary mechanism for interrupting antigen presentation has recently been suggested, where longer cognate interactions between $\mathrm{IL}-10^{+}$Bregs and $\mathrm{T}$ cells reduces the chances of effector $\mathrm{T}$ cells to encounter antigen-loaded DCs and become activated (52). The effects of murine IL$10^{+}$Bregs on DCs can be extrapolated to humans, as human B cells overexpressing IL-10 have been described to suppress differentiation of monocytes to DCs and to promote the generation of tolerogenic DCs (311).

Immune evasion processes involving IL- $10^{+}$Bregs can also be induced by neoplastic cells. The role of Bregs in cancer had already been suggested in experimental models, since mice lacking or depleted of B cells exhibit enhanced anti-tumor $\mathrm{CD} 8^{+}$ $\mathrm{T}$ cell responses and are resistant to tumor progression (312316). More recently, IL- $10^{+} \mathrm{B}$ cells and IL- $10^{+}$plasmablasts have been recovered from tumor or tumor draining lymph nodes, while cancer patients show increased circulating IL- $10^{+}$Bregs 
(82, 317-323). Tumor cells can induce B cells to secrete to IL-10 through multiple mechanisms including CD40L signals $(315,322)$ and tumor-derived exosomes $(324-327)$. In vitro and in vivo studies have demonstrated that $\mathrm{IL}-10^{+}$Bregs induced by mouse tumor cells are able to reduce IFN- $\gamma$ production by antigen-specific $\mathrm{CD}^{+}$and $\mathrm{CD} 4^{+}{ }^{+}$T cells as well as NK activation $(315,324)$. Adoptive transfer of B10 can also prevent antiCD20-mediated lymphoma depletion, likely through inhibiting macrophage activation (303). In a similar manner, tumorinduced human IL-10-producing B cells or plasmablasts have been described to suppress IFN- $\gamma$ and GrB expression by CD8 ${ }^{+}$ $\mathrm{T}$ cells $(317,318,321)$, as well as pro-inflammatory cytokines secreted by $\mathrm{CD}^{+} \mathrm{T}$ cells $(82,324,328)$. These effects can have an impact on tumoral cell survival, as demonstrated by a study where IL- $10^{+}$Bregs showed the ability to block antibodydependent cytotoxicity of NK on myeloma cells (329). These results have prompted the design of new therapeutic tools for cancer based on specific IL- $10^{+}$Breg-depletion, as recently published (330, 331).

In many cases, activated B cells can simultaneously produce other anti-inflammatory cytokines along with IL-10, such as TGF- $\beta$ and IL-35, which can be uniquely responsible for some of the immune regulatory properties assigned to Bregs, as described below.

\section{TGF- $\beta$}

The members of TGF- $\beta$ superfamily exhibit pleiotropic activities, the effects of which are both cell type- and context-dependent. TGF- $\beta$ participates in the regulation of $B$ cells at various stages of their development, with an important involvement in the control of self-tolerance and autoimmunity (332). On the other hand, evidence confirms that resting human B cells express TGF- $\beta$ and TGF- $\beta$ receptors, the expression of which is increased upon activation (333). It has been extensively described that several murine and human IL- $10^{+}$ Breg populations can also secrete TGF- $\beta$; however, in many cases, the role of TGF- $\beta$ suppression mediated by these cells has been excluded $(26,94,334,335)$. Nevertheless, in other cases, TGF- $\beta$ has been described to exert a dominant part in Breg functions. In particular, TGF- $\beta$ has the capacity to convert naïve $\mathrm{CD}^{+} \mathrm{T}$ cells into Tregs (336). Consequently, it was not surprising to find out that TGF- $\beta^{+}$Bregs are able to induce Tregs in healthy mice and humans $(194,337)$, as well as in inflammatory conditions such as transplantation (338), allergy $(339,340)$, and cancer $(86,341-343)$. In this regard, studies in a breast cancer model have described a population of $\mathrm{CD} 25^{\text {hi }} \mathrm{CD} 69^{\text {hi }}$ Bregs, induced by tumor-secreted factors such as leukotriene $\mathrm{B}_{4}$. These Bregs promote lung metastasis by inducing Tregs via STAT-3-dependent TGF- $\beta$ production $(86,342,344,345)$. In addition, TGF- $\beta$ secreted by tumor-evoked Bregs increased reactive-oxygen species and NO production by myeloid-derived suppressive cells, which in turn inhibited proliferation of $\mathrm{CD}^{+}$and $\mathrm{CD}^{+} \mathrm{T}$ cells, favoring metastasis (346).

Moreover, in accordance with the inhibitory functions of TGF- $\beta$ on effector T cell proliferation and differentiation, TGF$\beta^{+}$Bregs were reported to trigger anergy in $\mathrm{CD}^{+}$and $\mathrm{CD} 8^{+}$
$\mathrm{T}$ cells $(347,348)$. In a more recent study, it was detailed that transgenic mice deficient for TGF- $\beta 1$ specifically in B cells developed EAE at an accelerated rate compared to wild-type controls. This was associated with an increased frequency of activated DCs and an expansion of pathogenic IFN- $\gamma^{+}$IL-17 ${ }^{+}$ $\mathrm{CD} 4^{+} \mathrm{T}$ cells in the central nervous system, suggesting indirect control of inflammatory $\mathrm{T}$ cells by TGF- $\beta^{+}$Bregs (349). TGF$\beta$-producing Bregs can also be induced in mice infected with helminths. Such Bregs are able to suppress Th1- and/or Th2mediated colitis through a mechanism involving cooperation with anti-inflammatory macrophages (350). Noteworthy, TGF$\beta^{+}$Bregs have been described to be decreased in the alveoli of RA patients with interstitial lung disease (351), and in the blood of patients with myasthenia gravis (352), and increased in the blood of gastric cancer patients (341).

The phenotype of TGF- $\beta^{+}$Bregs has been poorly characterized. Some reports have identified them within the $\mathrm{CD}^{+}$or $\mathrm{CD} 25^{\text {hi }} \mathrm{CD} 69^{\text {hi }} \mathrm{B}$ cell populations in mouse $(86,353)$ and within the T2 transitional B cell subset in humans (341).

\section{IL-35}

IL-35, a potent anti-inflammatory cytokine, is the newest member of the IL-12 family of heterodimeric cytokines and is composed of the Ebi3 and the IL-12p35 chains. IL-35 has been described to be produced in large quantities by mouse and human Tregs and to be an important factor for their suppressive activities (354). Similarly, a role for IL-35 in Treg induction has been proposed; these Tregs then further mediate suppression via IL35 (355). However, whether other immune cell types can produce IL-35, and what functions this cytokine exerts, is a matter that had not been fully assessed until recently.

In this regard, Egwuagu and colleagues have shown that addition of IL-35 to LPS-stimulated human or murine B cells induces not only an expansion of IL- $10^{+}$Bregs but also the generation of IL-35-producing $\mathrm{B}$ cells $(89,356)$. These cells, named IL- $35^{+}$Bregs, develop spontaneously in mice with experimental autoimmune uveitis (EAU), exhibit a CD1d ${ }^{\text {hi }} \mathrm{CD} 21^{\text {hi }}$ phenotype, and are a major source of IL35. Furthermore, IL- $35^{+}$Bregs are expanded in vivo upon injection of IL-35, which is associated with an increase in Tregs, and a decrease in Th1 and Th17 cells via IL-10 and IL-35 production, reducing the severity of EAU $(89,356)$, but impairing protective immunity in a mycobacterial infection model (357). In parallel, Shen et al. described the ability of CD40 and TLR4 stimulation to induce IL-35 production by murine B cells. They also reported that a population of $\mathrm{CD}_{13} 8^{+}$plasma cells were the main producers of IL-35 in EAE mice and mice infected with Salmonella. B cell-restricted deletion of either IL-35 chain exacerbated EAE, but reduced Salmonella burden. These phenomena were correlated with exacerbated Th1 and Th17 responses and higher antigen-presenting capacity of B cells (16). The generation of IL- $35^{+}$Bregs appears to be mediated by the IL12 p35 subunit and IL-12R $\beta 2$, leading to the activation of STAT1, STAT3, IRF-4, IRF-8, and BATF $(89,147,356,358)$. Whether IL- $35^{+}$and IL- $10^{+}$Bregs correspond to separate populations 


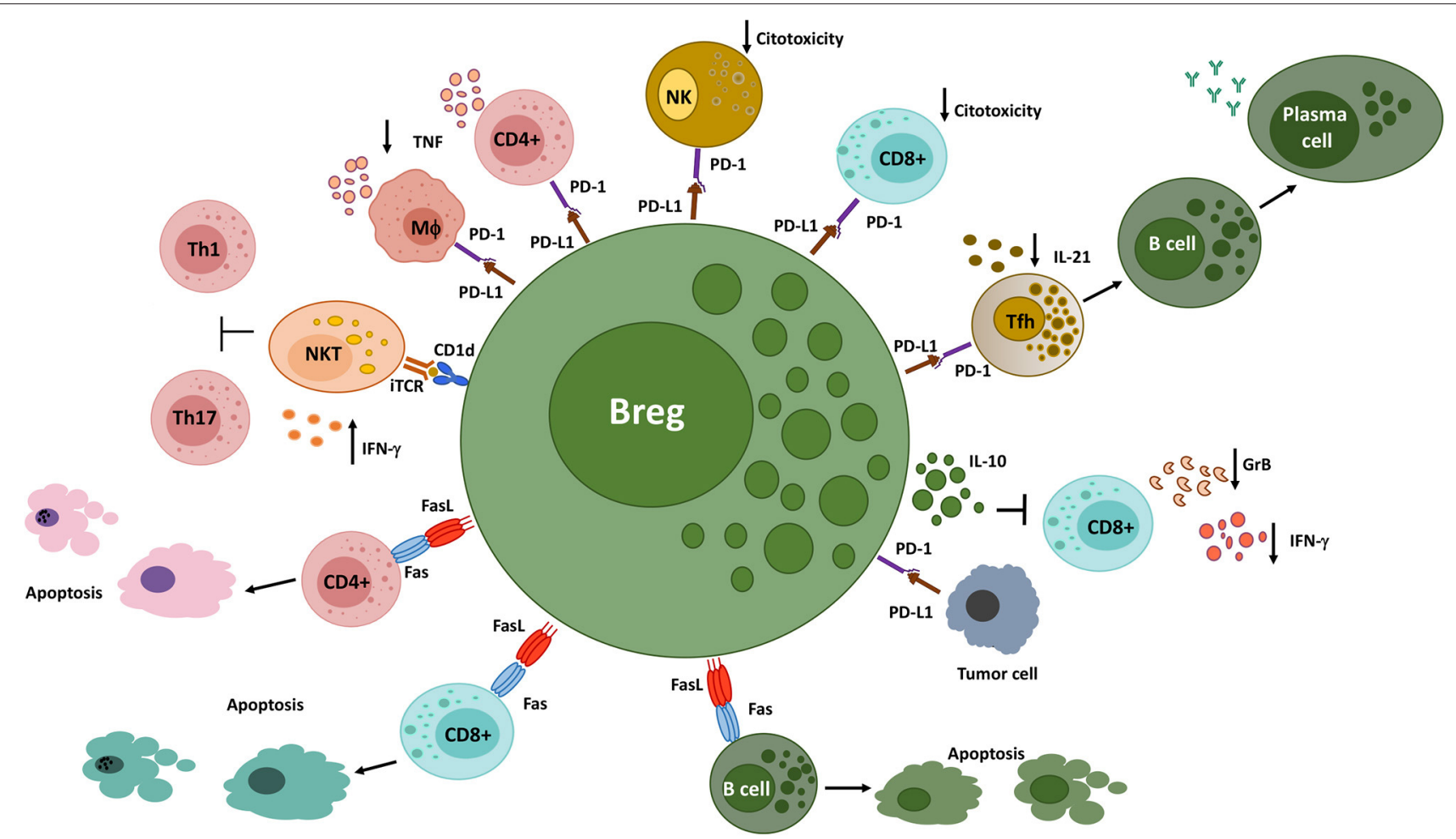

FIGURE 2 | Different Breg populations utilize cell surface-expressed molecules to suppress immune responses. Bregs interact with NKT cells via CD1d, inducing the production of IFN- $\gamma$, which inhibits Th1 and Th17 responses in a murine arthritis model. PD-L1+ Bregs decrease the production of pro-inflammatory cytokines by PD-1-expressing CD4 ${ }^{+} \mathrm{T}$ cells and macrophages and the cytotoxic functions of PD-1-expressing CD8 ${ }^{+} \mathrm{T}$ cells and NK cells. In addition, they interact with PD-1-expressing follicular helper T cells, leading to an inhibition of humoral immune responses. On the other hand, PD-L1 expressed on tumor cells engage PD-1 + Bregs, triggering the production of $\mathrm{IL}-10$ and the suppression of anti-tumor responses. Finally, FasL ${ }^{+} \mathrm{B}$ cells induce apoptosis on Fas-expressing CD4 ${ }^{+}$and $\mathrm{CD}^{+} \mathrm{T}^{-}$ cells, as well as on B cells. GrB, Granzyme B; iTCR, invariant T cell receptor; M $\Phi$, Macrophage; NK, Natural killer cell; NKT, Natural killer T cell; Tfh, Follicular helper T cell.

or display some degree of overlap is an issue that requires further clarification.

In a model of pancreatic ductal adenocarcinoma, IL- $35^{+}$ Bregs were found to be induced by IL- $1 \beta$ plus IL- 6 and CD40 stimulation and to participate in tumorigenesis (359). These results are in line with a previous study showing that IL- $35^{+} \mathrm{CD} 1 \mathrm{~d}^{\text {high }} \mathrm{B}$ cells are expanded in mouse and human pancreatic tumors and that these cells are able to promote tumor growth via IL-35 secretion (360). IL-35 ${ }^{+}$Bregs can also be generated from MZ B cells upon exposure to BAFF through the classical NF- $\kappa B$ pathway. These cells are increased in the spleen of mice with lupus and are able to suppress Th1 responses and expand Tregs in an IL-35-dependent manner (62). IL$35^{+}$Bregs have been detected in human decidua (361), while low frequencies have been found in decidua of abortion-prone mice (362). IL-35 ${ }^{+} \mathrm{B}$ cells have also been detected in intestinal mucosa from patients with Crohn's Disease (CD), but not from ulcerative colitis (UC) (363). Although IL-35 expression by in vitro-activated peripheral blood $\mathrm{B}$ cells is defective in $\mathrm{CD}$ patients, it can be rescued after incubation with exogenous IL35 , endowing them with enhanced suppressive capacities on pathogenic Th1 and Th17 cells (364). Similarly, Breg-mediated suppression of Th1 and Th17 responses in UC patients was restored upon addition of IL-35 (365), supporting the therapeutic use of IL-35 for inflammatory bowel diseases. Reduced frequency of IL-35 ${ }^{+}$Bregs in the peripheral blood has been observed in SLE patients (366), while increased frequencies of these cells have been reported in patients with active tuberculosis (367), leprosy (368), and gastric cancer (369). This further broadens the spectrum of conditions that could benefit from IL- $35^{+}$Bregtargeting therapies. Approaches to expand IL- $35^{+}$Bregs or IL$35^{+}$Tregs in vivo has already been tested, such as through the provision of IL-12p35 $(358,370)$, or the heterodimeric cytokine (89), as well as MSCs overexpressing IL-35 (371). A novel strategy using IL- $35^{+}$Breg-derived exosomes that contain bioactive IL35 has shown promising results as therapy in EAU; given the potential of exosomes to cross the blood-brain barrier, they could be considered for the treatment of autoimmune diseases affecting the central nervous system (372). Furthermore, studies of IL- $35^{+}$ Tregs have demonstrated that this cytokine is displayed on the plasma membrane and associated with the tetraspanin molecule CD81 and that its release in exosomes enables transfer of surface IL-35 to bystander B and T cells (373). These results, in addition to the evidence of IL-35-dependent conversion of IL-35 ${ }^{+}$Bregs 
and IL-35 ${ }^{+}$Tregs, have prompted the proposal of an "infectious tolerance" mechanism that could amplify the therapeutic effect of IL-35-containing exosomes (374).

\section{Granzyme B}

Bregs suppress inflammatory responses not only through the secretion of immunomodulatory cytokines but also through the release of cytotoxic GrB. Granzymes are a group of cytotoxic serine proteases that mediate target cell apoptosis upon entering the cytoplasm after perforin-mediated membrane disruption. There are 5 different types of granzymes in humans and there are 10 different types in mice. Among these, GrB has been described as the most powerful pro-apoptotic granzyme (375377). Furthermore, GrB can also play a role in tissue remodeling by cleaving a number of components of the extracellular matrix and, in inflammation, through the processing of IL- $1 \alpha$, IL-18, and TGF- $\beta$ (378-381).

Although GrB has been broadly described as part of the cytotoxicity machinery of activated $\mathrm{CD} 8^{+} \mathrm{T}$ cells and NK cells, Jahrsdörfer and colleagues described that BCR stimulation in the presence of IL-21, among other stimuli, can induce human B cells to secrete $\mathrm{GrB}$ and acquire cytotoxic potential. Several studies have shown $\mathrm{GrB}$ expression by other regulatory cell populations, such as Tregs and pDCs, which exert immunosuppressive functions over effector $\mathrm{T}$ cells, possibly mediated by perforinindependent degradation of the TCR $\zeta$-chain, together with other mechanisms (382-384). Following these studies, an immunosuppressive role for GrB-secreting B cells was evaluated, observing that these cells are able to inhibit $\mathrm{CD}^{+} \mathrm{T}$ cell proliferation, as well as Th1 and Th17 responses, by a mechanism involving a rapid GrB-mediated degradation of the $\zeta$-chain, but not $\mathrm{T}$ cell apoptosis $(385,386)$.

Moreover, $\mathrm{GrB}^{+} \mathrm{B}$ cells are expanded in subjects vaccinated against viral diseases, implying a regulatory function in antiviral immune responses $(190,385,387)$. Indeed, CD4 ${ }^{+} \mathrm{T}$ cells from HIV patients that secrete IL-21 but express low levels of CD40L are able to expand a population of suppressive $\mathrm{GrB}^{+}$ Bregs (388). Although initially GrB-producing B cells were identified among stimulated naïve $\mathrm{CD}_{27}^{-} \mathrm{IgD}^{-} \mathrm{IgM}^{+} \mathrm{CD}^{+}$cells, subsequent studies have also described other human $\mathrm{B}$ cell subsets with this capability, such as $\mathrm{IgD}^{-} \mathrm{CD} 27^{-}$double negative and memory B cells, as well as plasma cells (190, 389-391). It is important to consider that GrB expression has not been detected in murine B cells $(190,392)$.

Numerous studies have proposed a role for $\mathrm{GrB}^{+}$Bregs in controlling inflammatory processes, since alterations in this population have been described in immune-related conditions. For instance, functional impairments in peripheral blood $\mathrm{GrB}^{+}$ Bregs were found in RA patients, which were reversed after achieving clinical remission (386). Likewise, patients receiving a kidney graft showed a decreased frequency of $\mathrm{GrB}^{+}$Bregs, while an expansion of $\mathrm{GrB}^{+}$Bregs was found in patients developing kidney transplant tolerance $(390,393)$. Contrastingly, it has been shown that unstimulated B cells from SLE, RA, and pSS patients exhibit a high expression of GrB (394-396), and $\mathrm{GrB}^{+}$ plasma cells were increased in the lamina propria of patients with inflammatory bowel diseases (397). This implies that, depending on the context, $\mathrm{GrB}^{+}$Bregs can instead contribute to tissue damage secondary to autoimmune inflammation. Importantly, tumor- and lymph node-infiltrating $\mathrm{GrB}^{+}$Bregs have been described in several carcinomas; however, whether $\mathrm{GrB}^{+}$Bregs are important for anti-tumoral immunity or tumor evasion remains to be further elucidated $(385,398)$.

Although the abovementioned studies have confirmed the ability of B cells to secrete GrB to the extracellular milieu, a direct interaction with target cells has been proposed to be required for the inhibitory functions of $\mathrm{GrB}^{+}$Bregs $(385,390)$. This contact dependency is not exclusive for $\mathrm{GrB}^{+}$Bregs, as similar results have been described for IL- $10^{+}$Bregs $(26,265)$ and TGF$\beta^{+}$Bregs (399), suggesting that cell-to-cell contact interactions are important either to promote Bregs to secrete modulatory molecules or as an independent mechanism of suppression.

\section{SUPPRESSIVE MECHANISMS OF BREGS BY CELL SURFACE-EXPRESSED MOLECULES}

In the following section, we will discuss the suppressive mechanisms employed by Bregs through cell surface-expressed molecules (Figure 2), which can coexist or be autonomous from the soluble molecules examined above.

\section{CD1d}

CD1d is a non-polymorphic MHC class I-like molecule that presents glycolipid antigens to a subset of $\mathrm{T}$ cells called natural killer $\mathrm{T}$ (NKT) cells. NKT cells are innate-like $\mathrm{T}$ cells that rapidly respond to glycolipid antigen recognition through their TCR, by secreting abundant amounts of cytokines that lead to the activation of CD1d-expressing cells, such as monocytes, macrophages, DCs, and B cells (400). NKT cells are divided into two populations based on their TCR diversity: Type I or invariant (i)NKT cells, which exhibit a semi-invariant TCR that recognizes the exogenous lipid antigen $\alpha$-galactosylceramide $(\alpha$ GalCer), and type II NKT cells that have a more diverse TCR repertoire (401). Interestingly, the administration of $\alpha$-GalCer has shown to confer protection for a number of autoimmunity models, suggesting an immunoregulatory role for iNKT cells in certain conditions (402-404).

Among B cells, CD1d is most highly expressed on murine splenic CD24 ${ }^{\text {hi }} \mathrm{CD} 21^{\text {hi }} \mathrm{CD} 23^{\text {lo }} \mathrm{MZ}$ B cells and human MZ-like $\mathrm{B}$ cells and, to a lesser degree, by naïve and memory B cells. Once B cells present glycolipids to NKT cells via CD1d, activated NKT cells provide in return differentiating factors such IFN$\gamma$ and IL-4, allowing B cells to proliferate, mature, and secrete antibodies (405-408). In vitro, CD1d has been found to be upregulated shortly after CD40 activation (409). Early studies on different subsets of murine IL- $10^{+}$Bregs already described an upregulation of CD1d within these cells $(4,25,29,410)$. Moreover, CD1d expression on B cells was found to be essential for IL-10-dependent suppression of colitis (4). Similarly, human IL-10 ${ }^{+}$Bregs also express high levels of CD1d, as described for $\mathrm{T} 2$ transitional $\mathrm{B}$ cells, mature naïve $\mathrm{B}$ cells, and $\mathrm{CD} 5^{+} \mathrm{B}$ cells $(249,411,412)$. CD1d ${ }^{\text {hi }}$ Bregs have also been shown to 
concomitantly secrete TGF- $\beta$ in both mice and humans $(87,413)$. Despite these findings, a role for CD1d in mediating immune suppression by Bregs was not explored until recently.

Oleinika et al. demonstrated that $\alpha$-GalCer fail to protect mice from arthritis in the absence of CD1d-expressing B cells. This protection was attributed to T2-MZP and was independent of IL-10 secretion by B cells. The authors of this study proposed a model where T2-MZP B cells would present $\alpha$-GalCer via CD1d, inducing the secretion of IFN- $\gamma$ by iNKT cells, which in turn suppress Th1 and Th17 responses in arthritis (414). Although this study ruled out a requirement of iNKT cells for $\mathrm{IL}-10^{+} \mathrm{Breg}$ differentiation, previous findings have suggested that cognate interactions with iNKT cells can drive an expansion of Bregs $(415,416)$. Likewise, abnormalities in iNKT cell homeostasis have been attributed to dysfunctional CD1d-mediated presentation of self-lipids by $\mathrm{B}$ cells in autoimmunity-prone mice, thus confirming the importance of $\mathrm{CD} 1 \mathrm{~d}^{\mathrm{hi}} \mathrm{B}$ cells in maintaining self-tolerance (417).

In line with these results, several studies have observed alterations in the NKT compartment in patients with autoimmune diseases such as RA, SLE, and MS (418-421). Although the causes and consequences of these alterations are not fully understood, it has been shown in healthy individuals that B cells are essential for in vitro iNKT proliferation, activation, and cytokine production in a CDld-dependent fashion, a pathway that is defective in SLE patients. This defect could be explained by a decrease in CD1d surface expression on SLE transitional B cells due to a higher internalization rate (412).

\section{PD-1/PD-L1}

Immune checkpoints are inhibitory receptors that modulate the activation of immune cells in order to limit immune responses and preserve self-tolerance. The importance of immune checkpoints is highlighted not only by the success of therapeutic approaches blocking CTLA-4 and PD1 that boost anti-tumor responses in cancer patients but also by the autoimmune side effects unleashed by these drugs $(422,423)$. Experience from checkpoint blockade has inspired the design of therapies to activate immune checkpoints for the treatment of autoimmune diseases (424). Among these, there are increasing studies demonstrating the efficacy of PD- 1 activating therapies in mouse models of EAE, colitis and lupus, as well as in transplantation (425-429).

PD-1 is a type I transmembrane receptor expressed in activated monocytes, DCs, NKT cells, B cells, and T cells. The engagement of PD-1 by its ligands, PD-L1 and PD-L2, delivers inhibitory signals that downmodulate receptor-triggered cell survival, differentiation, and secretion of pro-inflammatory cytokines. PD-L1 is constitutively expressed on mouse T cells and $\mathrm{B}$ cells, DCs, and macrophages, among other cell types, while PDL2 expression is restricted to mature DCs, macrophages, mast cells, and a subset of B1 cells. PD-L1 and PD-L2 can also deliver reverse inhibitory signals upon PD-1 or CD80 engagement. Of note, both PD-1 and PD-L1 are highly expressed on Tregs and have been involved in Tregs induction and suppressive functions (430-433). These findings prompted investigations to discover similar functions of PD-1 and its ligands in Breg biology.
Studies have shown that some PD-1 $1^{+}$and PD-L1 ${ }^{+}$B cells co-express IL-10 and, that upon engagement of PD-1, suppress $\mathrm{CD}^{+}$and $\mathrm{CD} 8^{+} \mathrm{T}$ cell activity and induce Tr1 cells, suggesting a role of PD-1 in promoting IL-10 expression $(292,296,434,435)$. For instance, $\mathrm{CD} 5^{\text {hi }} \mathrm{PD}-1^{+} \mathrm{B}$ cells with a memory phenotype have been found to be enriched in hepatocellular carcinoma and to produce IL-10 upon PD-1 engagement by PD-L1 (436). Adoptive transfer of $\mathrm{CD} 5^{\text {hi }}{ }^{\mathrm{PD}}-1^{+} \mathrm{B}$ cells from hepatoma-bearing mice effectively suppressed $\mathrm{CD} 8^{+}$anti-tumor responses and promoted tumor growth (436). Another study reported that PD-L1 on human tumors can endow tumor-infiltrating B cells with Treginducing properties (437). Also, human PD- $1^{+}$PD-L $1^{\text {high }}$ Bregs infiltrating thyroid tumors were shown to decrease $\mathrm{CD}^{+}$and $\mathrm{CD}^{+} \mathrm{T}$ cell survival, an effect that was reversed by PD-L1 blockade (438). Nevertheless, other studies in cancer have shown that PD-L1 can mediate IL-10-independent suppression by B cells. In pancreatic cancer models, $\mathrm{PD}-\mathrm{L} 1^{+} \mathrm{B}$ cells were reported to inhibit NK and CD8 ${ }^{+} \mathrm{T}$ cell cytotoxicity via PD-L1 $(359,439)$. $\mathrm{PD}-\mathrm{L} 1^{+}$Bregs have also been described to be expanded in tumors and draining lymph nodes of mice bearing breast or cervical cancer $(399,440,441)$. In addition, PD-L1 ${ }^{+} \mathrm{B}$ cells have been identified within $\operatorname{IgA}^{+} \mathrm{B}$ cells in mice bearing liver tumors and have been proposed to mediate resistance to chemotherapy in prostate cancer, which can be overturned by PD-L1 blockade $(50,442)$. Altogether, these findings underscore a novel role of Bregs behind the mechanisms of action PD-1/PD-L1 targeting therapies in cancer.

$\operatorname{IgA}^{+}$plasma cells from small intestine lamina propria require both PD-L1 and PD-L2 to induce Tregs, suggesting that PD$1 / \mathrm{PD}-\mathrm{L}^{+}{ }^{+}$Bregs could be important in keeping peripheral tolerance (54). Along these lines, $\mathrm{IgA}{ }^{+} \mathrm{PD}-\mathrm{L} 1^{+}$Bregs were shown to dampen TNF production by macrophages and $\mathrm{T}$ cells and to ameliorate EAE development (61). Other PD-L1 ${ }^{+}$B cell subsets have also been shown to be essential for EAE protection by reducing Th1/Th17 responses (443-445). It has also been described that PD-L1-expressing Bregs have high avidity for BAFF and that these cells are spared after B cell depletion in EAE mice, an intervention that raises BAFF serum levels, revealing a novel aspect of a therapy that is successfully used in patients with MS (446). Furthermore, alterations in $\mathrm{PD}-\mathrm{L1}^{+}, \mathrm{PD}^{-\mathrm{L}^{+}}$, and $\mathrm{PD}-1^{+}$Bregs have been reported in patients with autoimmune conditions (237, 434, 447-450).

Inflammatory signals also trigger the upregulation of PD-L1 in B cells $(434,451)$. It has been described that PD-L1 expression on B cells is crucial in supporting the generation of long-lived plasma cells, limiting the expansion of PD-1-expressing Tfh cells but increasing the availability of IL-21 (452-455). However, a recent report showed that the adoptive transfer of PD-L1 ${ }^{\text {hi }} \mathrm{B}$ cells to EAE mice results in milder disease associated with a reduced Tfh-cell expansion, as well as decreased antigen-specific IgG and Th1/Th17 cells (446). These findings suggest that, during inflammation, expression of high levels of PD-L1 can endow $B$ cells with regulatory properties. Finally, PD-1 and PD-L1 expression on $\mathrm{B}$ cells was described to be upregulated by in vitro stimulation with Helicobacter and to mediate $\operatorname{Tr} 1$ differentiation (456). Moreover, PD-L1 upregulation on B cells, associated with $\mathrm{T}$ cell exhaustion, was observed in RSV-infected mice (457) and 
HIV-infected patients (455), suggesting a role for PD-L1 ${ }^{+}$Bregs as a mechanism to limit tissue damage that can be subverted by pathogens in their benefit.

\section{FasL (CD95L)}

Above, we have discussed the inactivation of immune cells through the secretion of $\mathrm{GrB}$ as one of the suppressive mechanisms displayed by Bregs. However, induction of anergy or apoptosis of activated $\mathrm{T}$ cells by Bregs can also rely on cell surface-expressed molecules (458). Ligation of the Fas death receptor (CD95) on activated $\mathrm{T}$ cells by FasL, a process known as activation-induced cell death, is a common apoptotic pathway. The Fas:FasL interaction is essential for the maintenance of selftolerance, as alterations in the expression of these molecules lead to spontaneous systemic autoimmunity in mice (459). Remarkably, selective deletion of FasL on B cells is able to break tolerance and drive $\mathrm{T}$ cell expansion and the production of autoantibodies (460). Expression of functional FasL in murine $\mathrm{B}$ cells has been described upon activation by LPS plus $\mathrm{P}+\mathrm{I}$ (461). In addition, FasL-expressing human B cells have been identified in tonsil GCs, in the bone marrow, and among plasma cells populating different tissues (462-464). Killer B cells constitutively expressing FasL were found to be expanded in autoimmune-prone mice, a finding that was also reported in peripheral blood of SLE and type 1 diabetes patients (465-467). Whether this expansion is due to compensatory mechanisms and/or contributed to the pathogenesis of autoimmune diseases is yet to be resolved; however, progress has been made in recent years.

The physiological relevance of $\mathrm{FasL}^{+} \mathrm{B}$ cells was assessed in the NOD mouse model of diabetes, where these cells promote apoptosis of diabetogenic $\mathrm{T}$ cells in vitro and a reduction of antigen-specific Th1 responses in vivo (468). FasL ${ }^{+}$B cells were also shown to directly mediate apoptosis of $\mathrm{CD}^{+} \mathrm{T}$ cells in a murine model of Schistosoma infection (469). During Schistosoma infection, constitutively high expression of FasL was found within splenic $\mathrm{CD}^{+} \mathrm{B}$ cells (470). Moreover, in arthritic mice, splenic $\mathrm{CD}^{+} \mathrm{FasL}^{+} \mathrm{B}$ cells reduced the frequency of pathogenic Th17 cells in a FasL-dependent manner (471). It was also shown that $\mathrm{FasL}^{+} \mathrm{B}$ cells fall into the $\mathrm{CD} 5^{+} \mathrm{CD} 1 \mathrm{~d}^{\text {hi }}$ population, and there was only partial overlap with $\mathrm{IL}-10^{+}$ Bregs $(472,473)$. Another population of $\mathrm{FasL}^{+}$Bregs have been described within immature $\mathrm{IgM}^{-} \mathrm{CD}^{+} \mathrm{d}^{+}$pro-B cells, which are able to kill effector $\mathrm{T}$ cells while protecting NOD mice from diabetes (474).

FasL $^{+}$Bregs can also be subverted by infectious agents to avoid inflammatory responses. $\mathrm{FasL}^{+}$Bregs have been detected upon in vitro infection with Epstein-Barr virus and in patients with filarial parasites or HIV infections (475-477). In these circumstances, $\mathrm{FasL}^{+}$Bregs can also induce the apoptosis of cytotoxic $\mathrm{CD}^{+} \mathrm{T}$ cells, which can correlate with a reduced control of the infection $(478,479)$. The targets of FasL ${ }^{+}$B cells are not restricted to $\mathrm{T}$ cells, as shown in a murine model of Trypanosoma infection, where a "fratricide" killing of parasitespecific B cells has been described $(480,481)$. Furthermore, in an inflammatory context, $\mathrm{FasL}^{+} \mathrm{B}$ cells can also induce apoptosis of non-immune cells, such as pulmonary epithelial cells in an acute lung injury model (482). Besides, $\mathrm{FasL}^{+} \mathrm{B}$ cells recovered from tumor-draining lymph nodes were capable of killing tumor cells in vitro $(483,484)$. Taken together, these results show that FasL ${ }^{+}$ Bregs are generated under inflammatory conditions and that they may play a role in the maintenance of peripheral tolerance and control of exacerbated responses but can also be responsible for inflammation-induced damage and anti-tumoral immunity.

It is worthwhile noting that B cells have been reported to induce contact-dependent apoptosis or immune modulation through other members of the TNF family, such as membranebound TNF (485), GITR (486), and TRAIL (487, 488). In addition, recent studies have shown that IL- $10^{+}$Bregs from RA patients can acquire ectopic expression of RANKL, an important molecule involved in osteoclast activation and bone destruction (489).

\section{TIM-1-EXPRESSING BREGS (TIM-1+ BREGS)}

TIM- $1^{+}$Bregs are a newly discovered population of human and murine Bregs that has gained increasing attention, since TIM$1^{+}$Bregs phenotypically and functionally overlap with many of the abovementioned subsets, including IL- $10^{+}$Bregs, TGF- $\beta^{+}$ Bregs, and PD-L1 ${ }^{+}$Bregs. TIM-1 can function as a receptor that licenses B cells to express suppressive cytokines or ligands, although, a contact-dependent effect on immune cells expressing TIM-1-binding partners has not been excluded so far.

TIM receptors represent a family of molecules that play critical roles in the regulation of immune responses. To date, four members of this family have been identified in mice (TIM-1,-2,-3,-4) and three in humans (TIM-1,-3, and-4) (490). TIM-1 is expressed in several immune cells, including activated T cells, Th2 cells, B cells, NKT cells, macrophages, and DCs, whereas TIM-4, one of the ligands for TIM-1, is expressed on monocytes, macrophages, and DCs (491). TIM1 has been described as a phosphatidylserine (PS) receptor mediating phagocytosis of apoptotic bodies and in the regulation of immune responses (492). In T cells, TIM-1 functions as a costimulation signal, inducing $\mathrm{T}$ cell activation and IL-4 secretion $(493,494)$. In DCs, TIM-1-mediated signaling promotes their maturation, enhancing their ability to induce Th17 responses and inhibit the generation of Tregs, implying a cell-dependent fine-tuning of TIM-1 functions (495).

Early studies identified TIM-1 expression in murine GC B cells $(496,497)$. Later on, it was shown that mice treated with a lowaffinity agonistic anti-TIM-1 antibody, either alone or in addition to anti-CD45RB, displayed long-term tolerance to allografts, an effect that was completely reversed in the absence of $B$ cells. $B$ cells were shown to be responsible for anti-TIM-1-mediated Th2 responses and IL-10 production by Tregs in these settings. TIM- $1^{+}$B cells were enriched in IL- 4 - and, importantly, TGF- $\beta$ and IL-10-producing cells, regardless of the developmental stage or anatomic localization of these populations and were induced and expanded after transplantation or anti-TIM-1 treatment in grafted mice. Both IL-10 and TGF- $\beta$ have been found to be essential for antigen-specific tolerogenic properties of adoptively 


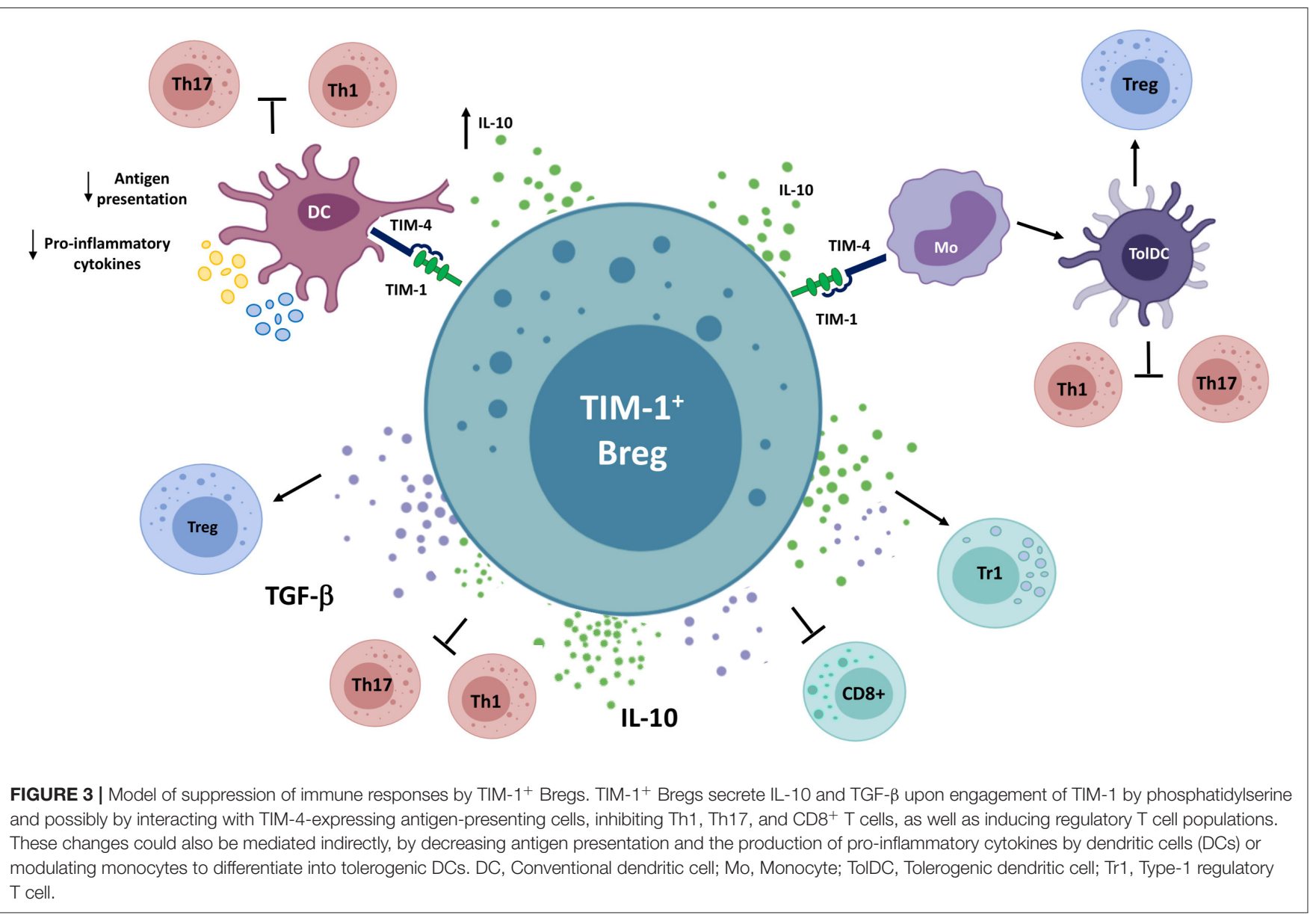

transferred TIM- $1^{+}$Bregs $(52,91,498-500)$. The regulatory nature of $\mathrm{TIM}-1^{+}$B cells was further validated in different models, as the transfer of these cells can reduce the severity of allergic airway inflammation (91) and colitis (501), while promoting tumor growth $(183,502)$. These results support a role of TIM- 1 as an encompassing IL- $10^{+}$and TGF- $\beta^{+}$Breg marker with functional implications.

Subsequently, it was demonstrated that the mucin domain of TIM-1 was crucial for IL-10 induction by B cells following stimulation with PS-containing apoptotic cells, suggesting a physiologic pathway whereby dying cells promote tolerance to self-antigens and resolution of inflammation by activating IL- $10^{+}$TIM- $1^{+}$Bregs (503-505). This proposition is further sustained by observations in mice with a B cell-specific deletion of TIM-1 or mice lacking the mucin domain of TIM-1, which present a profound defect in IL- $10^{+}$Bregs and multi-organ tissue inflammation. Furthermore, these mice exhibit a severe EAE course or accelerated lupus-like syndrome on a susceptible background $(506,507)$. Moreover, amelioration of EAE following inoculation with apoptotic cells was abrogated in recipient mice with TIM-1-deficient B cells, showing expanded Th1/Th17 responses and reduced Treg generation (508).

Accordingly, in vitro and in vivo studies have demonstrated that murine TIM-1 ${ }^{+}$Bregs are able to inhibit the differentiation of Th1 or Th17 cells and to promote Treg and $\operatorname{Tr} 1$ generation, which has been primarily attributed to the production of IL-10 or TGF- $\beta$, although cytokine-independent mechanisms have also been suggested $(91,183,500,507-510)$. In this regard, a recent study has revealed that the expression of the immune checkpoint TIGIT is enriched among TIM-1 $1^{+}$Bregs and depends on TIM-1 signaling and subsequent activation of AhR. TIGIT-deficient B cells showed an impaired IL-10 production, facilitating the development of spontaneous neuroinflammation with infiltration of Th1 and Th17 cells. In addition, these mice presented a more severe EAE, while transfer of TIM- $1^{+}$B cells from TIGIT-deficient mice showed reduced ability to ameliorate EAE. Since not all TIGIT $^{+}$B cells express IL-10, and vice versa, these results suggest that TIGIT expression can be an independent mechanism of suppression by TIM- $1^{+}$Bregs (507).

A number of reports showing the expression of TIM-1 in human B cells have been published in recent years. In accordance with mouse data, studies in healthy donors and HIV patients found an enrichment of IL-10-producing cells within TIM-1 $1^{+}$B cells. In patients with HIV infection, TIM-1 ${ }^{+}$ $B$ cells specific for HIV antigens suppressed IL-17 and IFN$\gamma$ production by HIV-specific $\mathrm{CD} 8^{+}$and $\mathrm{CD} 4^{+} \mathrm{T}$ cells, which was partially reversed by IL-10 blockade $(293,511)$. Human IL- $10^{+}$TIM- $1^{+}$Bregs can also be found infiltrating tumors 
and have been described to suppress $\mathrm{CD} 8^{+}$and $\mathrm{CD} 4^{+} \mathrm{T}$ cell anti-tumor responses $(323,512,513)$. The utility of TIM-1 as a marker for a proportion of human IL- $10^{+}$Bregs has been further confirmed in inflammatory and autoimmune diseases, such as in RA patients, who exhibit reduced frequencies of TIM-1 ${ }^{+}$Bregs (514). In agreement with these studies, we reported that TIM-1 and IL-10 were preferentially co-expressed in transitional B cells from healthy donors upon BCR and TLR9 activation; however, this population is significantly decreased in patients with systemic sclerosis (SSc). In addition, TIM$1^{+}$Bregs from SSc patients exhibited an impaired suppression of pro-inflammatory cytokines by $\mathrm{CD} 4^{+} \mathrm{T}$ cells (515). As for mice, human TIM-1 ${ }^{+}$Bregs have also been proven to secrete TGF- $\beta$, together with IL-10, and to promote Tregs differentiation, which seems to be mediated by TGF- $\beta$ (510, 516).

Therefore, it is becoming apparent that TIM- $1^{+}$Bregs have a regulatory role in the homeostasis of the immune system, but more studies are necessary to unveil the mechanisms that this population employs for such effects. Currently, our group is characterizing the influence of TIM-4 and TIM-4-expressing cells in the activation of TIM-1 $1^{+}$Bregs. Previous studies using a fusion Fc-TIM-4 murine protein have shown that TIM4 binds to and activates TIM- 1 expressed on T cells (490, 517, 518). Human and murine TIM-4 are expressed in APCs, recognize PS, and are important for the clearance of apoptotic cells $(490,519,520)$. This has led to the interpretation that TIM-1:TIM-4 interactions could be bridged by PS-containing exosomes $(519,521)$. Additionally, TIM- $4^{+}$myeloid cells have been encountered infiltrating human tumors in close vicinity to $\mathrm{TIM}-1^{+}$B cells, which suggests that myeloid cells could induce TIM- $^{+}$Bregs to produce IL-10 through TIM-1:TIM4 interactions (513). We have preliminary data indicating that TIM- $1^{+}$Bregs directly interact with TIM $-4^{+}$APCs and decrease their antigen presentation capacity, as well as the production of pro-inflammatory cytokines. From these data, and previous evidence, we postulate that TIM-1 ${ }^{+}$Bregs could be involved in tolerance induction both directly acting on $\mathrm{T}$ cells and indirectly by modulating TIM-4-expressing APCs or generating tolerogenic DCs, which result in the suppression of pro-inflammatory $\mathrm{T}$ cells and the induction of Tregs (Figure 3).

\section{REFERENCES}

1. Mauri C, Bosma A. Immune regulatory function of B cells. Annu Rev Immunol. (2012) 30:221-41. doi: 10.1146/annurev-immunol-020711-074934

2. Wolf SD, Dittel BN, Hardardottir F, Janeway CA. Experimental autoimmune encephalomyelitis induction in genetically B celldeficient mice. J Exp Med. (1996) 184:2271-8. doi: 10.1084/jem.184. 6.2271

3. Mauri C, Gray D, Mushtaq N, Londei M. Prevention of arthritis by interleukin 10-producing B cells. J Exp Med. (2003) 197:489501. doi: 10.1084/jem.20021293

4. Mizoguchi A, Mizoguchi E, Takedatsu H, Blumberg RS, Bhan AK. Chronic intestinal inflammatory condition generates IL-10-producing regulatory $\mathrm{B}$ cell subset characterized by CD1d upregulation. Immunity. (2002) 16:21930. doi: 10.1016/S1074-7613(02)00274-1

\section{CONCLUDING REMARKS}

The crucial role of Bregs in homeostasis and different immune conditions is now emerging in the literature, as new evidence confirms them as an important member of the immunosuppressive cell family. However, much needs to be elucidated regarding their origin, phenotype, function, and suppressive mechanisms. Experimental studies have focused on soluble mediators as the main regulatory molecules of Bregs. On the other hand, research on surface molecules that allow Bregs to establish cellular interactions with other cell populations and convey inhibitory signals is lagging behind. Herein, we have aimed to consolidate and update the current knowledge about the cellular and molecular regulatory mechanisms that are exhibited by Bregs and identify the main cell populations targeted by them. It is conceivable that the considerable phenotypical and functional Breg heterogeneity is required to effectively limit inflammation and reestablish immune homeostasis in diverse anatomical sites, stages of the inflammatory process, and pathological conditions. Understanding how Bregs are able to exercise their suppressive action will be of great importance when applying the biological function of Bregs in clinical settings.

\section{AUTHOR CONTRIBUTIONS}

DC, OA, MAM, AF, KO, JCA, and LS discussed the contents, wrote, reviewed, and edited the manuscript. All authors listed approved the version to be published and have made a substantial and intellectual contribution to the work.

\section{FUNDING}

This work was financed by the National Agency for Research and Development ANID-Fondecyt Iniciación Grant Number 11170800. Doctoral training of AF was supported by ANID-PFCHA/National Doctoral Scholarship No 21181286.

\section{ACKNOWLEDGMENTS}

Some of the figures were generated by adapting the bioRENDER templates.

5. Palomares O, Akdis M, Martín-Fontecha M, Akdis CA. Mechanisms of immune regulation in allergic diseases: the role of regulatory $\mathrm{T}$ and $\mathrm{B}$ cells. Immunol Rev. (2017) 278:219-36. doi: 10.1111/imr.12555

6. Alhabbab RY, Nova-Lamperti E, Aravena O, Burton HM, Lechler RI, Dorling A, et al. Regulatory B cells: development, phenotypes, functions, and role in transplantation. Immunol Rev. (2019) 292:164-79. doi: 10.1111/imr.12800

7. Sarvaria A, Madrigal JA, Saudemont A. B cell regulation in cancer and anti-tumor immunity. Cell Mol Immunol. (2017) 14:662-74. doi: $10.1038 / \mathrm{cmi} .2017 .35$

8. Fillatreau S. Regulatory roles of B cells in infectious diseases. Clin Exp Rheumatol. (2016) 34:1-5.

9. Strom AC, Cross AJ, Cole JE, Blair PA, Leib C, Goddard ME, et al. B regulatory cells are increased in hypercholesterolaemic mice and protect from lesion development via IL-10. Thromb Haemost. (2015) 114:83547. doi: 10.1160/TH14-12-1084 
10. Fillatreau S, Sweenie CH, McGeachy MJ, Gray D, Anderton SM. B cells regulate autoimmunity by provision of IL-10. Nat Immunol. (2002) 3:94450. doi: $10.1038 / \mathrm{ni} 833$

11. Carter NA, Vasconcellos R, Rosser EC, Tulone C, Muñoz-Suano A, Kamanaka M, et al. Mice lacking endogenous IL-10-producing regulatory B cells develop exacerbated disease and present with an increased frequency of Th1/Th17 but a decrease in regulatory T cells. J Immunol. (2011) 186:556979. doi: 10.4049/jimmunol.1100284

12. Lin W, Cerny D, Chua E, Duan K, Yi JTJ, Shadan NB, et al. Human regulatory $\mathrm{B}$ cells combine phenotypic and genetic hallmarks with a distinct differentiation fate. J Immunol. (2014) 193:2258-66. doi: 10.4049/jimmunol.1303214

13. Sun J, Wang J, Pefanis E, Chao J, Rothschild G, Tachibana I, et al. Transcriptomics identify CD9 as a marker of murine IL-10-competent regulatory B cells. Cell Rep. (2015) 13:11107. doi: 10.1016/j.celrep.2015.09.070

14. Piper CJM, Rosser EC, Oleinika K, Nistala K, Krausgruber T, Rendeiro $\mathrm{AF}$, et al. Aryl hydrocarbon receptor contributes to the transcriptional program of IL-10-producing regulatory B cells. Cell Rep. (2019) 29:187892.e7. doi: 10.1016/j.celrep.2019.10.018

15. Lino AC, Dang VD, Lampropoulou V, Welle A, Joedicke J, Pohar J, et al. LAG-3 inhibitory receptor expression identifies immunosuppressive natural regulatory plasma cells. Immunity. (2018) 49:120-33.e9. doi: 10.1016/j.immuni.2018.06.007

16. Shen P, Roch T, Lampropoulou V, O'Connor RA, Stervbo U, Hilgenberg E, et al. IL-35-producing B cells are critical regulators of immunity during autoimmune and infectious diseases. Nature. (2014) 507:36670. doi: 10.1038/nature12979

17. Van De Veen W, Stanic B, Yaman G, Wawrzyniak M, Söllner S, Akdis DG, et al. IgG4 production is confined to human IL-10-producing regulatory B cells that suppress antigen-specific immune responses. J Allergy Clin Immunol. (2013) 131:1204-12. doi: 10.1016/j.jaci.2013.01.014

18. Lighaam LC, Unger P-PA, Vredevoogd DW, Verhoeven D, Vermeulen $\mathrm{E}$, Turksma AW, et al. In vitro-induced human IL-10+ B cells do not show a subset-defining marker signature and plastically coexpress IL-10 with pro-inflammatory cytokines. Front Immunol. (2018) 9:1913. doi: 10.3389/fimmu.2018.01913

19. Heine G, Drozdenko G, Grün JR, Chang HD, Radbruch A, Worm M. Autocrine IL-10 promotes human B-cell differentiation into IgM- or IgG-secreting plasmablasts. Eur J Immunol. (2014) 44:1615-21. doi: 10.1002/eji.201343822

20. Rosser EC, Mauri C. Regulatory B cells: origin, phenotype, and function. Immunity. (2015) 42:607-12. doi: 10.1016/j.immuni.2015.04.005

21. Rosser EC, Oleinika K, Tonon S, Doyle R, Bosma A, Carter NA, et al. Regulatory B cells are induced by gut microbiota-driven interleukin- $1 \beta$ and interleukin-6 production. Nat Med. (2014) 20:1334-9. doi: 10.1038/nm.3680

22. Mackay F, Schneider P, Rennert P, Browning J. BAFF and APRIL: a tutorial on B cell survival. Annu Rev Immunol. (2003) 21:23164. doi: 10.1146/annurev.immunol.21.120601.141152

23. Yang M, Sun L, Wang S, Ko K-H, Xu H, Zheng B-J, et al. Cutting edge: novel function of $\mathrm{B}$ cell-activating factor in the induction of IL-10-producing regulatory B cells. J Immunol. (2010) 184:3321-5. doi: 10.4049/jimmunol.0902551

24. Saulep-Easton D, Vincent FB, Quah PS, Wei A, Ting SB, Croce CM, et al. The BAFF receptor TACI controls IL-10 production by regulatory $B$ cells and CLL B cells. Leukemia. (2016) 30:163-72. doi: 10.1038/leu.20 15.174

25. Evans JG, Chavez-Rueda KA, Eddaoudi A, Meyer-Bahlburg A, Rawlings DJ, Ehrenstein MR, et al. Novel suppressive function of transitional 2 B cells in experimental arthritis. J Immunol. (2007) 178:786878. doi: 10.4049/jimmunol.178.12.7868

26. Blair PA, Noreña LY, Flores-Borja F, Rawlings DJ, Isenberg DA, Ehrenstein MR, et al. CD19+CD24hiCD38hi B cells exhibit regulatory capacity in healthy individuals but are functionally impaired in systemic lupus erythematosus patients. Immunity. (2010) 32:129-40. doi: 10.1016/j.immuni.2009.11.009

27. Simon Q, Pers JO, Cornec D, Le Pottier L, Mageed RA, Hillion S. In-depth characterization of CD24highCD38high transitional human B cells reveals different regulatory profiles. J Allergy Clin Immunol. (2016) 137:157784.e10. doi: 10.1016/j.jaci.2015.09.014

28. Lenert P, Brummel R, Field EH, Ashman RF. TLR-9 activation of marginal zone $\mathrm{B}$ cells in lupus mice regulates immunity through increased IL-10 production. J Clin Immunol. (2005) 25:29-40. doi: 10.1007/s10875-005-0355-6

29. Yanaba K, Bouaziz JD, Haas KM, Poe JC, Fujimoto M, Tedder TF. A regulatory $\mathrm{B}$ cell subset with a unique CD1dhiCD5+ phenotype controls $\mathrm{T}$ cell-dependent inflammatory responses. Immunity. (2008) 28:63950. doi: 10.1016/j.immuni.2008.03.017

30. Iwata Y, Matsushita T, Horikawa M, DiLillo DJ, Yanaba K, Venturi $\mathrm{GM}$, et al. Characterization of a rare IL-10-competent B-cell subset in humans that parallels mouse regulatory B10 cells. Blood. (2011) 117:53041. doi: 10.1182/blood-2010-07-294249

31. Yanaba K, Bouaziz J-D, Matsushita T, Tsubata T, Tedder TF. The development and function of regulatory B cells expressing IL-10 (B10 cells) requires antigen receptor diversity and TLR signals. J Immunol. (2009) 182:7459-72. doi: 10.4049/jimmunol.0900270

32. Tedder TF. B10 cells: a functionally defined regulatory B cell subset. $J$ Immunol. (2015) 194:1395-401. doi: 10.4049/jimmunol.1401329

33. Matsushita T, Yanaba K, Bouaziz J-D, Fujimoto M, Tedder TF. Regulatory B cells inhibit EAE initiation in mice while other B cells promote disease progression. J Clin Invest. (2008) 118:3420-30. doi: 10.1172/JCI36030

34. Watanabe R, Ishiura N, Nakashima H, Kuwano Y, Okochi H, Tamaki K, et al. Regulatory B cells (B10 cells) have a suppressive role in murine lupus: CD19 and B10 cell deficiency exacerbates systemic autoimmunity. J Immunol. (2010) 184:4801-9. doi: 10.4049/jimmunol.0902385

35. Yanaba K, Yoshizaki A, Asano Y, Kadono T, Tedder TF, Sato S. IL-10producing regulatory B10 cells inhibit intestinal injury in a mouse model. Am J Pathol. (2011) 178:735-43. doi: 10.1016/j.ajpath.2010.10.022

36. Yang $M$, Deng J, Liu Y, Ko K-H, Wang X, Jiao Z, et al. IL-10Producing regulatory $\mathrm{B} 10$ cells ameliorate collagen-induced arthritis via suppressing Th17 cell generation. Am J Pathol. (2012) 180:237585. doi: 10.1016/j.ajpath.2012.03.010

37. Le Huu D, Matsushita T, Jin G, Hamaguchi Y, Hasegawa M, Takehara K, et al. Donor-derived regulatory B cells are important for suppression of murine sclerodermatous chronic graft-versus-host disease. Blood. (2013) 121:3274-83. doi: 10.1182/blood-2012-11-465658

38. Baumgarth N. A Hard(y) look at B-1 cell development and function. J Immunol. (2017) 199:3387-94. doi: 10.4049/jimmunol.1700943

39. O'garra A, Howard M. IL-10 production by CD5 B cells. Ann N Y Acad Sci. (1992) 651:182-99. doi: 10.1111/j.1749-6632.1992.tb24615.x

40. Griffin DO, Rothstein TL. Human B1 cell frequency: isolation and analysis of human B1 cells. Front Immunol. (2012) 3:122. doi: 10.3389/fimmu.2012.00122

41. Margry B, Kersemakers SCW, Hoek A, Arkesteijn GJA, Wieland WH, van Eden W, et al. Activated peritoneal cavity B-1a cells possess regulatory B cell properties. PLoS ONE. (2014) 9:e88869. doi: 10.1371/journal.pone.00 88869

42. Maseda D, Candando KM, Smith SH, Kalampokis I, Weaver CT, Plevy SE, et al. Peritoneal cavity regulatory B cells (B10 cells) modulate IFN- $\gamma+$ CD4 $+\mathrm{T}$ cell numbers during colitis development in mice. J Immunol. (2013) 191:2780-95. doi: 10.4049/jimmunol.1300649

43. Madan R, Demircik F, Surianarayanan S, Allen JL, Divanovic S, Trompette A, et al. Nonredundant roles for B cell-derived IL-10 in immune counterregulation. J Immunol. (2009) 183:2312-20. doi: 10.4049/jimmunol.0900185

44. Zhang X, Deriaud E, Jiao X, Braun D, Leclerc C, Lo-Man R. Type I interferons protect neonates from acute inflammation through interleukin 10-producing B cells. J Exp Med. (2007) 204:1107-18. doi: 10.1084/jem.200 62013

45. Zhivaki D, Lemoine S, Lim A, Morva A, Vidalain PO, Schandene L, et al. Respiratory syncytial virus infects regulatory B cells in human neonates via chemokine receptor CX3CR1 and promotes lung disease severity. Immunity. (2017) 46:301-14. doi: 10.1016/j.immuni.2017.01.010

46. Mizoguchi A, Bhan AK. A case for regulatory B cells. J Immunol. (2006) 176:705-10. doi: 10.4049/jimmunol.176.2.705

47. Zhang X. Regulatory functions of innate-like B cells. Cell Mol Immunol. (2013) 10:113-21. doi: 10.1038/cmi.2012.63 
48. Meng L, Almeida LN, Clauder A-K, Lindemann T, Luther J, Link C, et al. Bone marrow plasma cells modulate local myeloid-lineage differentiation via IL-10. Front Immunol. (2019) 10:1183. doi: 10.3389/fimmu.2019.01183

49. Neves P, Lampropoulou V, Calderon-Gomez E, Roch T, Stervbo U, Shen $\mathrm{P}$, et al. Signaling via the MyD88 adaptor protein in B cells suppresses protective immunity during salmonella typhimurium infection. Immunity. (2010) 33:777-90. doi: 10.1016/j.immuni.2010.10.016

50. Shalapour S, Font-Burgada J, Di Caro G, Zhong Z, SanchezLopez E, Dhar D, et al. Immunosuppressive plasma cells impede T-cell-dependent immunogenic chemotherapy. Nature. (2015) 521:94-8. doi: 10.1038/nature14395

51. Rojas OL, Pröbstel AK, Porfilio EA, Wang AA, Charabati M, Sun T, et al. Recirculating intestinal IgA-producing cells regulate neuroinflammation via IL-10. Cell. (2019) 176:610-24.e18. doi: 10.1016/j.cell.2018.11.035

52. Mohib K, Cherukuri A, Zhou Y, Ding Q, Watkins SC, Rothstein DM. Antigen-dependent interactions between regulatory $\mathrm{B}$ cells and $\mathrm{T}$ cells at the T:B border inhibit subsequent T cell interactions with DCs. Am J Transplant. (2020) 20:52-63. doi: 10.1111/ajt.15546

53. De Masson A, Bouaziz JD, Le Buanec H, Robin M, O'Meara A, Parquet $\mathrm{N}$, et al. CD24hiCD27+ and plasmablast-like regulatory $\mathrm{B}$ cells in human chronic graft-versus-host disease. Blood. (2015) 125:1830-9. doi: 10.1182/blood-2014-09-5 99159

54. Doi T, Kanai T, Mikami Y, Sujino T, Jun L, Ono Y, et al. IgA plasma cells express the negative regulatory co-stimulatory molecule programmed cell death 1 ligand and have a potential tolerogenic role in the intestine. Biochem Biophys Res Commun. (2012) 425:918-23. doi: 10.1016/j.bbrc.2012.08.010

55. Matsumoto M, Baba A, Yokota T, Nishikawa $H$, Ohkawa $\mathrm{Y}$, Kayama $\mathrm{H}$, et al. Interleukin-10-producing plasmablasts exert regulatory function in autoimmune inflammation. Immunity. (2014) 41:1040-51. doi: 10.1016/j.immuni.2014.10.016

56. Maseda D, Smith SH, DiLillo DJ, Bryant JM, Candando KM, Weaver CT, et al. Regulatory B10 cells differentiate into antibody-secreting cells after transient IL-10 production in vivo. J Immunol. (2012) 188:103648. doi: 10.4049/jimmunol.1102500

57. Rafei M, Hsieh J, Zehntner S, Li M, Forner K, Birman E, et al. A granulocytemacrophage colony-stimulating factor and interleukin-15 fusokine induces a regulatory B cell population with immune suppressive properties. Nat Med. (2009) 15:1038-45. doi: 10.1038/nm.2003

58. Bibby JA, Purvis HA, Hayday T, Chandra A, Okkenhaug K, Rosenzweig $\mathrm{S}$, et al. Cholesterol metabolism drives regulatory B cell IL-10 through provision of geranylgeranyl pyrophosphate. Nat Commun. (2020) 11:3412. doi: 10.1038/s41467-020-17179-4

59. Jenks SA, Cashman KS, Zumaquero E, Marigorta UM, Patel AV, Wang $\mathrm{X}$, et al. Distinct effector B cells induced by unregulated toll-like receptor 7 contribute to pathogenic responses in systemic lupus erythematosus. Immunity. (2018) 49:725-39.e6. doi: 10.1016/j.immuni.2018.08.015

60. Hua C, Audo R, Yeremenko N, Baeten D, Hahne M, Combe B, et al. A proliferation inducing ligand (APRIL) promotes IL-10 production and regulatory functions of human B cells. J Autoimmun. (2016) 73:6472. doi: $10.1016 /$ j.jaut.2016.06.002

61. Fehres CM, van Uden NO, Yeremenko NG, Fernandez L, Franco Salinas G, van Duivenvoorde LM, et al. APRIL induces a novel subset of IgA+ regulatory B cells that suppress inflammation via expression of IL-10 and PD-L1. Front Immunol. (2019) 10:1368. doi: 10.3389/fimmu.2019.01368

62. Zhang Y, Li J, Zhou N, Zhang Y, Wu M, Xu J, et al. The unknown aspect of BAFF: inducing IL-35 production by a CD5+CD1dhiFc $\gamma$ RIIbhi regulatory B-cell subset in lupus. J Invest Dermatol. (2017) 137:253243. doi: 10.1016/j.jid.2017.07.843

63. Planelles L, Carvalho-Pinto CE, Hardenberg G, Smaniotto S, Savino W, Gómez-Caro R, et al. APRIL promotes B-1 cell-associated neoplasm. Cancer Cell. (2004) 6:399-408. doi: 10.1016/j.ccr.2004.08.033

64. den Hartog G, van Osch TLJ, Vos M, Meijer B, Savelkoul HFJ, van Neerven RJJ, et al. BAFF augments IgA2 and IL-10 production by TLR7/8 stimulated total peripheral blood B cells. Eur J Immunol. (2018) 48:28392. doi: 10.1002/eji.201646861

65. Menon M, Blair PA, Isenberg DA, Mauri C. A regulatory feedback between plasmacytoid dendritic cells and regulatory $\mathrm{B}$ cells is aberrant in systemic lupus erythematosus. Immunity.

(2016) 44:683-97. doi: 10.1016/j.immuni.2016.02.012

66. Liu B-S, Cao Y, Huizinga TW, Hafler DA, Toes REM. TLR-mediated STAT3 and ERK activation controls IL-10 secretion by human B cells. Eur J Immunol. (2014) 44:2121-9. doi: 10.1002/eji.201344341

67. Bankó Z, Pozsgay J, Szili D, Tóth M, Gáti T, Nagy G, et al. Induction and differentiation of IL-10-producing regulatory B cells from healthy blood donors and rheumatoid arthritis patients. J Immunol. (2017) 198:151220. doi: 10.4049/jimmunol.1600218

68. Yang X, Yang J, Chu Y, Wang J, Guan M, Zhu X, et al. T follicular helper cells mediate expansion of regulatory B cells via IL-21 in lupus-prone MRL/lpr mice. PLoS ONE. (2013) 8:e62855. doi: 10.1371/journal.pone.0062855

69. Hu Y, Yu P, Yu X, Hu X, Kawai T, Han X. IL-21/anti-Tim1/CD40 ligand promotes B10 activity in vitro and alleviates bone loss in experimental periodontitis in vivo. Biochim Biophys Acta Mol Basis Dis. (2017) 1863:214957. doi: 10.1016/j.bbadis.2017.06.001

70. Yoshizaki A, Miyagaki T, Dilillo DJ, Matsushita T, Horikawa M, Kountikov EI, et al. Regulatory B cells control T-cell autoimmunity through IL-21-dependent cognate interactions. Nature. (2012) 491:2648. doi: 10.1038/nature11501

71. King C, Tangye SG, Mackay CR. T follicular helper (TFH) cells in normal and dysregulated immune responses. Annu Rev Immunol. (2008) 26:74166. doi: 10.1146/annurev.immunol.26.021607.090344

72. Greenwald RJ, Freeman GJ, Sharpe AH. The B7 family revisited. Annu Rev Immunol. (2005) 23:51548. doi: 10.1146/annurev.immunol.23.021704.115611

73. Jelcic I, Al Nimer F, Wang J, Lentsch V, Planas R, Jelcic I, et al. Memory B cells activate brain-homing, autoreactive CD4+ T cells in multiple sclerosis. Cell. (2018) 175:85-100.e23. doi: 10.1016/j.cell.2018.08.011

74. Crawford A, MacLeod M, Schumacher T, Corlett L, Gray D. Primary T cell expansion and differentiation in vivo requires antigen presentation by $\mathrm{B}$ cells. J Immunol. (2006) 176:3498-506. doi: 10.4049/jimmunol.176.6.3498

75. Molnarfi N, Schulze-Topphoff U, Weber MS, Patarroyo JC, Prod'homme T, Varrin-Doyer M, et al. MHC class II-dependent B cell APC function is required for induction of CNS autoimmunity independent of myelin-specific antibodies. J Exp Med. (2013) 210:2921-37. doi: 10.1084/jem.20130699

76. Kleindienst $\mathrm{P}$, Brocker T. Concerted antigen presentation by dendritic cells and B cells is necessary for optimal CD4 T-cell immunity in vivo. Immunology. (2005) 115:556-64. doi: 10.1111/j.1365-2567.2005.02196.x

77. Giles JR, Kashgarian M, Koni PA, Shlomchik MJ. B cell-specific MHC class II deletion reveals multiple nonredundant roles for B cell antigen presentation in murine lupus. J Immunol. (2015) 195:25719. doi: 10.4049/jimmunol.1500792

78. Murray SE, Toren KG, Parker DC. Peripheral CD4+ T-cell tolerance is induced in vivo by rare antigen-bearing $\mathrm{B}$ cells in follicular, marginal zone, and B-1 subsets. Eur J Immunol. (2013) 43:1818-27. doi: 10.1002/eji.201242784

79. Morlacchi S, Soldani C, Viola A, Sarukhan A. Self-antigen presentation by mouse $B$ cells results in regulatory T-cell induction rather than anergy or clonal deletion. Blood. (2011) 118:984-91. doi: 10.1182/blood-2011-02-336115

80. Mizoguchi E, Mizoguchi A, Preffer FI, Bhan AK. Regulatory role of mature B cells in a murine model of inflammatory bowel disease. Int Immunol. (2000) 12:597-605. doi: 10.1093/intimm/12.5.597

81. Mann MK, Maresz K, Shriver LP, Tan Y, Dittel BN. B cell regulation of CD4 $+\mathrm{CD} 25+\mathrm{T}$ regulatory cells and IL-10 via B7 is essential for recovery from experimental autoimmune encephalomyelitis. J Immunol. (2007) 178:344756. doi: 10.4049/jimmunol.178.6.3447

82. Hu HT, Ai X, Lu M, Song Z, Li H. Characterization of intratumoral and circulating IL-10-producing B cells in gastric cancer. Exp Cell Res. (2019) 384:111652. doi: 10.1016/j.yexcr.2019.111652

83. Salomon B, Lenschow DJ, Rhee L, Ashourian N, Singh B, Sharpe $\mathrm{A}$, et al. B7/CD28 costimulation is essential for the homeostasis of the CD4+CD25+ immunoregulatory $\mathrm{T}$ cells that control autoimmune diabetes. Immunity. (2000) 12:431-40. doi: 10.1016/S1074-7613(00)8 0195-8

84. Manzotti CN, Tipping H, Perry LCA, Mead KI, Blair PJ, Zheng Y, et al. Inhibition of human $\mathrm{T}$ cell proliferation by CTLA- 4 utilizes CD80 
and requires CD25+ regulatory T cells. Eur J Immunol. (2002) 32:288896. doi: 10.1002/1521-4141(2002010)32:10<2888::AID-IMMU2888>3.0. $\mathrm{CO} ; 2-\mathrm{F}$

85. Zheng Y, Manzotti CN, Liu M, Burke F, Mead KI, Sansom DM. CD86 and CD80 differentially modulate the suppressive function of human regulatory T cells. J Immunol. (2004) 172:2778-84. doi: 10.4049/jimmunol.172.5.2778

86. Olkhanud PB, Damdinsuren B, Bodogai M, Gress RE, Sen R, Wejksza K, et al. Tumor-evoked regulatory $B$ cells promote breast cancer metastasis by converting resting CD4+ T cells to T-regulatory cells. Cancer Res. (2011) 71:3505-15. doi: 10.1158/0008-5472.CAN-10-4316

87. Kessel A, Haj T, Peri R, Snir A, Melamed D, Sabo E, et al. Human CD19+CD25high B regulatory cells suppress proliferation of CD4+ T cells and enhance Foxp3 and CTLA-4 expression in T-regulatory cells. Autoimmun Rev. (2012) 11:670-7. doi: 10.1016/j.autrev.2011.11.018

88. Matsushita T, Le Huu D, Kobayashi T, Hamaguchi Y, Hasegawa M, Naka K, et al. A novel splenic B1 regulatory cell subset suppresses allergic disease through phosphatidylinositol 3-kinase-Akt pathway activation. J Allergy Clin Immunol. (2016) 138:1170-82.e9. doi: 10.1016/j.jaci.2015.12.1319

89. Wang RX, Yu CR, Dambuza IM, Mahdi RM, Dolinska MB, Sergeev YV, et al. Interleukin-35 induces regulatory B cells that suppress autoimmune disease. Nat Med. (2014) 20:633-41. doi: 10.1038/nm.3554

90. Heine G, Niesner U, Chang HD, Steinmeyer A, Zügel U, Zuberbier T, et al. 1,25-dihydroxyvitamin D3 promotes IL-10 production in human B cells. Eur J Immunol. (2008) 38:2210-8. doi: 10.1002/eji.200838216

91. Ding Q, Yeung M, Camirand G, Zeng Q, Akiba H, Yagita H, et al. Regulatory B cells are identified by expression of TIM-1 and can be induced through TIM-1 ligation to promote tolerance in mice. J Clin Invest. (2011) 121:364556. doi: $10.1172 / J C I 46274$

92. Lampropoulou V, Hoehlig K, Roch T, Neves P, Gómez EC, Sweenie CH, et al. TLR-activated B cells suppress T cell-mediated autoimmunity. J Immunol. (2008) 180:4763-73. doi: 10.4049/jimmunol.180.7.4763

93. Barr TA, Brown S, Ryan G, Zhao J, Gray D. TLR-mediated stimulation of APC: distinct cytokine responses of B cells and dendritic cells. Eur J Immunol. (2007) 37:3040-53. doi: 10.1002/eji.200636483

94. Blair PA, Chavez-Rueda KA, Evans JG, Shlomchik MJ, Eddaoudi A, Isenberg $\mathrm{DA}$, et al. Selective targeting of B cells with agonistic anti-CD40 is an efficacious strategy for the generation of induced regulatory T2-like B cells and for the suppression of lupus in MRL/ lpr Mice. J Immunol. (2009) 182:3492-502. doi: 10.4049/jimmunol.0803052

95. Bouaziz JD, Calbo S, Maho-Vaillant M, Saussine A, Bagot M, Bensussan A, et al. IL-10 produced by activated human B cells regulates CD4+ T-cell activation in vitro. Eur J Immunol. (2010) 40:2686-91. doi: 10.1002/eji.201040673

96. Komlósi ZI, Kovács N, van de Veen W, Kirsch AI, Fahrner HB, Wawrzyniak $\mathrm{M}$, et al. Human CD40 ligand-expressing type 3 innate lymphoid cells induce IL-10-producing immature transitional regulatory B cells. J Allergy Clin Immunol. (2018) 142:178-94.e11. doi: 10.1016/j.jaci.2017. 07.046

97. Kim HS, Kim AR, Kim DK, Kim HW, Park YH, Jang GH, et al. Interleukin-10-producing CD5+ B cells inhibit mast cells during immunoglobulin E-mediated allergic responses. Sci Signal. (2015) 8:ra28. doi: 10.1126/scisignal.2005861

98. Mion F, D’Incà F, Danelli L, Toffoletto B, Guarnotta C, Frossi B, et al. Mast cells control the expansion and differentiation of IL-10-competent B cells. J Immunol. (2014) 193:4568-79. doi: 10.4049/jimmunol.1302593

99. Müller J, Nitschke L. The role of CD22 and Siglec$\mathrm{G}$ in B-cell tolerance and autoimmune disease. Nat Rev Rheumatol. (2014) 10:422-8. doi: 10.1038/nrrheum.2 014.54

100. Poe JC, Smith SH, Haas KM, Yanaba K, Tsubata T, Matsushita T, et al. Amplified B lymphocyte CD40 signaling drives regulatory B10 cell expansion in mice. PLoS ONE. (2011) 6:e22464. doi: 10.1371/journal.pone.00 22464

101. Nakashima H, Hamaguchi Y, Watanabe R, Ishiura N, Kuwano Y, Okochi H, et al. CD22 expression mediates the regulatory functions of peritoneal B1a cells during the remission phase of contact hypersensitivity reactions. $J$ Immunol. (2010) 184:4637-45. doi: 10.4049/jimmunol.0901719
102. Tsubata T. CD72 is a negative regulator of B cell responses to nuclear lupus self-antigens and development of systemic lupus erythematosus. Immune Netw. (2019) 19:e1. doi: 10.4110/in.2019.19.e1

103. Duddy ME, Alter A, Bar-Or A. Distinct profiles of human B cell effector cytokines: a role in immune regulation? I Immunol. (2004) 172:34227. doi: $10.4049 /$ jimmunol.172.6.3422

104. Jin G, Hamaguchi Y, Matsushita T, Hasegawa M, Le Huu D, Ishiura N, et al. B-cell linker protein expression contributes to controlling allergic and autoimmune diseases by mediating IL-10 production in regulatory B cells. $J$ Allergy Clin Immunol. (2013) 131:1674-82.e9. doi: 10.1016/j.jaci.2013.01.044

105. Matsumoto M, Fujii Y, Baba A, Hikida M, Kurosaki T, Baba Y. The calcium sensors STIM1 and STIM2 control B cell regulatory function through interleukin-10 production. Immunity. (2011) 34:70314. doi: 10.1016/j.immuni.2011.03.016

106. Ziegler S, Gartner K, Scheuermann U, Zoeller T, Hantzschmann J, Over $\mathrm{B}$, et al. $\mathrm{Ca}^{2+}$-related signaling events influence TLR9-induced IL-10 secretion in human B cells. Eur J Immunol. (2014) 44:128598. doi: 10.1002/eji.201343994

107. Rangaswamy US, Speck SH. Murine gammaherpesvirus M2 protein induction of IRF4 via the NFAT pathway leads to IL-10 expression in B cells. PLoS Pathog. (2014) 10:e1003858. doi: 10.1371/journal.ppat.1003858

108. Suzuki-Yamazaki N, Yanobu-Takanashi R, Okamura T, Takaki S. IL-10 production in murine IgM $+\mathrm{CD} 138 \mathrm{hi}$ cells is driven by Blimp-1 and downregulated in class-switched cells. Eur J Immunol. (2017) 47:493503. doi: 10.1002/eji.201646549

109. Wang Y-H, Tsai D-Y, Ko Y-A, Yang T-T, Lin I-Y, Hung K-H, et al. Blimp1 contributes to the development and function of regulatory B cells. Front Immunol. (2019) 10:1909. doi: 10.3389/fimmu.2019.01909

110. Jeffries MA, Obr AE, Urbanek K, Fyffe-Maricich SL, Wood TL. Cnp promoter-driven sustained ERK1/2 activation increases B-cell activation and suppresses experimental autoimmune encephalomyelitis. ASN Neuro. (2020) 12:1-18. doi: 10.1177/1759091420971916

111. Liu M, Zhao X, Ma Y, Zhou Y, Deng M, Ma Y. Transcription factor c-Maf is essential for IL-10 gene expression in B cells. Scand J Immunol. (2018) 88:e12701. doi: 10.1111/sji.12701

112. Apetoh L, Quintana FJ, Pot C, Joller N, Xiao S, Kumar D, et al. The aryl hydrocarbon receptor interacts with c-Maf to promote the differentiation of type 1 regulatory T cells induced by IL-27. Nat Immunol. (2010) 11:85461. doi: 10.1038/ni.1912

113. Rosser EC, Piper CJM, Matei DE, Blair PA, Rendeiro AF, Orford M, et al. Microbiota-derived metabolites suppress arthritis by amplifying arylhydrocarbon receptor activation in regulatory B cells. Cell Metab. (2020) 31:837-51.e10. doi: 10.1016/j.cmet.2020.03.003

114. Alhabbab R, Blair P, Elgueta R, Stolarczyk E, Marks E, Becker PD, et al. Diversity of gut microflora is required for the generation of $\mathrm{B}$ cell with regulatory properties in a skin graft model. Sci Rep. (2015) 5:11554. doi: 10.1038/srep11554

115. Ochoa-Repáraz J, Mielcarz DW, Haque-Begum S, Kasper LH. Induction of a regulatory B cell population in experimental allergic encephalomyelitis by alteration of the gut commensal microflora. Gut Microbes. (2010) 1:1038. doi: 10.4161/gmic.1.2.11515

116. Mercadante ACT, Perobelli SM, Alves APG, Gonçalves-Silva T, Mello W, Gomes-Santos AC, et al. Oral combined therapy with probiotics and alloantigen induces B cell-dependent long-lasting specific tolerance. $J$ Immunol. (2014) 192:1928-37. doi: 10.4049/jimmunol.1301034

117. Xu LZ, Yang LT, Qiu SQ, Yang G, Luo XQ, Miao BP, et al. Combination of specific allergen and probiotics induces specific regulatory B cells and enhances specific immunotherapy effect on allergic rhinitis. Oncotarget. (2016) 7:54360-9. doi: 10.18632/oncotarget.10946

118. Sutavani RV, Phair IR, Barker R, McFarlane A, Shpiro N, Lang S, et al. Differential control of Toll-like receptor 4-induced interleukin-10 induction in macrophages and B cells reveals a role for p90 ribosomal S6 kinases. J Biol Chem. (2018) 293:2302-17. doi: 10.1074/jbc.M117.805424

119. Syedbasha M, Bonfiglio F, Linnik J, Stuehler C, Wüthrich D, Egli A. Interferon- $\lambda$ enhances the differentiation of naive $B$ cells into plasmablasts via the mTORC1 pathway. Cell Rep. (2020) 33:108211. doi: 10.1016/j.celrep.2020.108211 
120. Latorre I, Esteve-Sole A, Redondo D, Giest S, Argilaguet J, Alvarez S, et al. Calcineurin and mTOR inhibitors have opposing effects on regulatory T cells while reducing regulatory B cell populations in kidney transplant recipients. Transpl Immunol. (2016) 35:1-6. doi: 10.1016/j.trim.2016.01.004

121. Li J, Gao J, Zhou H, Zhou J, Deng Z, Lu Y, et al. Inhibition of glycogen synthase kinase $3 \beta$ increases the proportion and suppressive function of CD19+CD24hiCD27+ Breg cells. Front Immunol. (2020) 11:603288. doi: 10.3389/fimmu.2020.603288

122. Angela M, Endo Y, Asou HK, Yamamoto T, Tumes DJ, Tokuyama H, et al. Fatty acid metabolic reprogramming via mTOR-mediated inductions of PPAR $\gamma$ directs early activation of T cells. Nat Commun. (2016) 7:13683. doi: $10.1038 /$ ncomms 13683

123. Xu Z, Wang G, Zhu Y, Liu R, Song J, Ni Y, et al. PPAR- $\gamma$ agonist ameliorates liver pathology accompanied by increasing regulatory $\mathrm{B}$ and $\mathrm{T}$ cells in high-fat-diet mice. Obesity. (2017) 25:581-90. doi: 10.1002/oby.21769

124. Su J, Wang K, Zhou X, Wang Y, Xu J, Tao L, et al. B-cell-specificperoxisome proliferator-activated receptor $\gamma$ deficiency augments contact hypersensitivity with impaired regulatory B cells. Immunology. (2019) 156:282-96. doi: 10.1111/imm.13027

125. Nishimura S, Manabe I, Takaki S, Nagasaki M, Otsu M, Yamashita H, et al. Adipose natural regulatory $\mathrm{B}$ cells negatively control adipose tissue inflammation. Cell Metab. (2013) 18:759-66. doi: 10.1016/j.cmet.2013.09.017

126. Zheng $\mathrm{Z}$, Liu $\mathrm{T}$, Li X, Ding J, Feng $\mathrm{Y}$, Miao J, et al. Kinetic changes of regulatory B10 cells in collagen-induced arthritis could be regulated by cytokines IFN- $\gamma$ and TGF- $\beta 1$. Inflamm Res. (2015) 64:63745. doi: 10.1007/s00011-015-0846-5

127. Holan V, Zajicova A, Javorkova E, Trosan P, Chudickova M, Pavlikova M, et al. Distinct cytokines balance the development of regulatory $\mathrm{T}$ cells and interleukin-10-producing regulatory B cells. Immunology. (2014) 141:57786. doi: 10.1111/imm.12219

128. Barátki BL, Huber K, Sármay G, Matkó J, Kövesdi D. Inflammatory signal induced IL-10 production of marginal zone B-cells depends on CREB. Immunol Lett. (2019) 212:14-21. doi: 10.1016/j.imlet.2019.06.004

129. Huber K, Sármay G, Kövesdi D. MZ B cells migrate in a T-bet dependent manner and might contribute to the remission of collagen-induced arthritis by the secretion of IL-10. Eur J Immunol. (2016) 46:223946. doi: 10.1002/eji.201546248

130. Ticha O, Moos L, Wajant H, Bekeredjian-Ding I. Expression of tumor necrosis factor receptor 2 characterizes TLR9-driven formation of interleukin-10-producing B cells. Front Immunol. (2017) 8:1951. doi: 10.3389/fimmu.2017.01951

131. Kim HS, Lee JH, Han HD, Kim AR, Nam ST, Kim HW, et al. Autocrine stimulation of IL-10 is critical to the enrichment of IL-10-producing cd40hicd5+ regulatory b cells in vitro and in vivo. BMB Rep. (2015) 48:549. doi: 10.5483/BMBRep.2015.48.1.213

132. Zhu Z, Zhang Y, Ye J, Wang X, Fu X, Yin Y, et al. IL-35 promoted STAT3 phosphorylation and IL-10 production in B cells, but its production was reduced in patients with coronary artery diseases. Hum Immunol. (2018) 79:869-75. doi: 10.1016/j.humimm.2018.10.009

133. Cho KA, Lee JK, Kim YH, Park M, Woo SY, Ryu KH. Mesenchymal stem cells ameliorate B-cell-mediated immune responses and increase IL10-expressing regulatory B cells in an EBI3-dependent manner. Cell Mol Immunol. (2017) 14:895-908. doi: 10.1038/cmi.2016.59

134. Li H, Deng Y, Liang J, Huang F, Qiu W, Zhang M, et al. Mesenchymal stromal cells attenuate multiple sclerosis via IDO-dependent increasing the suppressive proportion of CD5+ IL-10+ B cells. Am J Transl Res. (2019) 11:5673-88.

135. Chao K, Zhang S, Qiu Y, Chen X, Zhang X, Cai C, et al. Human umbilical cord-derived mesenchymal stem cells protect against experimental colitis via CD5+ B regulatory cells. Stem Cell Res Ther. (2016) 7:112. doi: 10.1186/s13287-016-0376-2

136. Chen X, Cai C, Xu D, Liu Q, Zheng S, Liu L, et al. Human mesenchymal stem cell-treated regulatory CD23+CD43+ B cells alleviate intestinal inflammation. Theranostics. (2019) 9:4633-47. doi: 10.7150/thno.32260

137. Lu D, Ma T, Zhou XB, Jiang YM, Han Y, Li H. B lymphocytes are the target of mesenchymal stem cells immunoregulatory effect in a murine graft-versus-host disease model. Cell Transplant. (2019) 28:127988. doi: 10.1177/0963689719860127
138. Peng Y, Chen X, Liu Q, Zhang X, Huang K, Liu L, et al. Mesenchymal stromal cells infusions improve refractory chronic graft versus host disease through an increase of CD5+ regulatory B cells producing interleukin 10. Leukemia. (2015) 29:636-46. doi: 10.1038/leu.2014.225

139. Perico N, Casiraghi F, Todeschini M, Cortinovis M, Gotti E, Portalupi V, et al. Long-term clinical and immunological profile of kidney transplant patients given mesenchymal stromal cell immunotherapy. Front Immunol. (2018) 9:1359. doi: 10.3389/fimmu.2018.01359

140. Wang H, Qi F, Dai X, Tian W, Liu T, Han H, et al. Requirement of B7$\mathrm{H} 1$ in mesenchymal stem cells for immune tolerance to cardiac allografts in combination therapy with rapamycin. Transpl Immunol. (2014) 31:6574. doi: 10.1016/j.trim.2014.06.005

141. Lan X, Wang G, Xu X, Lu S, Li X, Zhang B, et al. Stromal cell-derived factor-1 mediates cardiac allograft tolerance induced by human endometrial regenerative cell-based therapy. Stem Cells Transl Med. (2017) 6:19972008. doi: 10.1002/sctm.17-0091

142. Sattler S, Ling GS, Xu D, Hussaarts L, Romaine A, Zhao H, et al. IL10-producing regulatory B cells induced by IL-33 (BregIL-33) effectively attenuate mucosal inflammatory responses in the gut. J Autoimmun. (2014) 50:107-22. doi: 10.1016/j.jaut.2014.01.032

143. Zhu J, Xu Y, Zhu C, Zhao J, Meng X, Chen S, et al. IL-33 induces both regulatory $\mathrm{B}$ cells and regulatory $\mathrm{T}$ cells in dextran sulfate sodium-induced colitis. Int Immunopharmacol. (2017) 46:3847. doi: 10.1016/j.intimp.2017.02.006

144. Sheng JR, Quan S, Soliven B. CD1d hi CD5 + B cells expanded by GM-CSF in vivo suppress experimental autoimmune myasthenia gravis. J Immunol. (2014) 193:2669-77. doi: 10.4049/jimmunol.1303397

145. Giacomini E, Rizzo F, Etna MP, Cruciani M, Mechelli R, Buscarinu MC, et al. Thymosin- $\alpha 1$ expands deficient IL-10-producing regulatory B cell subsets in relapsing-remitting multiple sclerosis patients. Mult Scler. (2018) 24:127-39. doi: 10.1177/1352458517695892

146. Rolle L, Memarzadeh Tehran M, Morell-García A, Raeva Y, Schumacher A, Hartig R, et al. Cutting edge: IL-10-producing regulatory B cells in early human pregnancy. Am J Reprod Immunol. (2013) 70:44853. doi: $10.1111 /$ aji.12157

147. Liu J, Chen X, Hao S, Zhao H, Pang L, Wang L, et al. Human chorionic gonadotropin and IL-35 contribute to the maintenance of peripheral immune tolerance during pregnancy through mediating the generation of IL-10+ or IL-35+ Breg cells. Exp Cell Res. (2019) 383:111513. doi: 10.1016/j.yexcr.2019.111513

148. Fettke F, Schumacher A, Canellada A, Toledo N, Bekeredjian-Ding I, Bondt A, et al. Maternal and fetal mechanisms of B cell regulation during pregnancy: human chorionic gonadotropin stimulates B cells to produce IL-10 while alpha-fetoprotein drives them into apoptosis. Front Immunol. (2016) 7:495. doi: 10.3389/fimmu.2016.00495

149. Eriksen AB, Berge T, Gustavsen MW, Leikfoss IS, Bos SD, Spurkland A, et al. Retinoic acid enhances the levels of IL-10 in TLR-stimulated B cells from patients with relapsing-remitting multiple sclerosis. J Neuroimmunol. (2015) 278:11-8. doi: 10.1016/j.jneuroim.2014.11.019

150. Meng X, Grötsch B, Luo Y, Knaup KX, Wiesener MS, Chen XX, et al. Hypoxia-inducible factor- $1 \alpha$ is a critical transcription factor for IL10-producing B cells in autoimmune disease. Nat Commun. (2018) 9:117. doi: 10.1038/s41467-017-02683-x

151. Geng XR, Yang G, Li M, Song JP, Liu ZQ, Qiu S, et al. Insulin-like growth factor-2 enhances functions of antigen (Ag)-specific regulatory B cells. J Biol Chem. (2014) 289:17941-50. doi: 10.1074/jbc.M113.5 15262

152. Guo X, Li MG, Li SS, Liu FH, Liu ZJ, Yang PC. Tumor necrosis factor suppresses interleukin 10 in peripheral $B$ cells via upregulating $\mathrm{Bcl}$-like protein 12 in patients with inflammatory bowel disease. Cell Biochem Funct. (2017) 35:77-82. doi: 10.1002/cb f. 3250

153. Shao JB, Luo XQ, Wu YJ, Li MG, Hong JY, Mo LH, et al. Histone deacetylase 11 inhibits interleukin 10 in B cells of subjects with allergic rhinitis. Int Forum Allergy Rhinol. (2018) 8:1274-83. doi: 10.1002/alr.22171

154. Ren ZQ, Liu N, Zhao K. Micro RNA-19a suppresses IL-10 in peripheral B cells from patients with atherosclerosis. Cytokine. (2016) 86:8691. doi: 10.1016/j.cyto.2016.07.019 
155. Liu ZQ, Yang G, Geng XR, Liu JQ, Mo LH, Liu ZG, et al. Micro RNA-17-92 cluster mediates interleukin-4-suppressed IL-10 expression in B cells. Am J Transl Res. (2016) 8:2317-24.

156. Li MY, Zhu M, Linghu EQ, Feng F, Zhu B, Wu C, et al. Interleukin-13 suppresses interleukin-10 via inhibiting A20 in peripheral B cells of patients with food allergy. Oncotarget. (2016) 7:79914-24. doi: 10.18632/oncotarget.13107

157. Lin R-T, Liu J-Q, Lu H-Y, Chen Y-M, Guan L, Liu Z-G, et al. Micro RNA-155 plays a critical role in the initiation of food allergenrelated inflammation in the intestine. Oncotarget. (2017) 8:67497505. doi: 10.18632/oncotarget.18723

158. Li Y, Rong J, Qin J, He J, Chen H, Huang S. Micro RNA-98 interferes with expression interleukin-10 in peripheral B cells of patients with lung cancer. Sci Rep. (2016) 6:32754. doi: 10.1038/srep32754

159. Wang C, You Q, Cao X, Guo H, Gao X, Peng X. Micro RNA-19a suppresses interleukin-10 in peripheral $\mathrm{B}$ cells of patients with diabetic retinopathy. Am J Transl Res. (2017) 9:1410-7.

160. Wang Z, Cheng Q, Tang K, Sun Y, Zhang K, Zhang Y, et al. Lipid mediator lipoxin A4 inhibits tumor growth by targeting IL10-producing regulatory B (Breg) cells. Cancer Lett. (2015) 364:11824. doi: 10.1016/j.canlet.2015.04.030

161. Hermankova B, Zajicova A, Javorkova E, Chudickova M, Trosan P, Hajkova M, et al. Suppression of IL-10 production by activated B cells via a cell contact-dependent cyclooxygenase-2 pathway upregulated in IFN- $\gamma$-treated mesenchymal stem cells. Immunobiology. (2016) 221:12936. doi: 10.1016/j.imbio.2015.09.017

162. Bommer I, Muzzio DO, Zygmunt M, Jensen F. Progesterone and estradiol exert an inhibitory effect on the production of anti-inflammatory cytokine IL-10 by activated MZ B cells. J Reprod Immunol. (2016) 116:1136. doi: 10.1016/j.jri.2016.05.008

163. Chen R, Cao Y, Tian Y, Gu Y, Lu H, Zhang S, et al. PGE2 ameliorated viral myocarditis development and promoted IL-10-producing regulatory $\mathrm{B}$ cell expansion via MAPKs/AKT-AP1 axis or AhR signaling. Cell Immunol. (2020) 347:104025. doi: 10.1016/j.cellimm.2019.104025

164. Bohacova P, Kossl J, Hajkova M, Hermankova B, Javorkova E, Zajicova $\mathrm{A}$, et al. Interleukin-10 production by B cells is regulated by cytokines, but independently of GATA-3 or FoxP3 expression. Cell Immunol. (2020) 347:103987. doi: 10.1016/j.cellimm.2019.103987

165. Kawano M, Takagi R, Saika K, Matsui M, Matsushita S. Dopamine regulates cytokine secretion during innate and adaptive immune responses. Int Immunol. (2018) 30:591-606. doi: 10.1093/intimm/dxy057

166. Pongratz G, Melzer M, Straub RH. The sympathetic nervous system stimulates anti-inflammatory B cells in collagen-type II-induced arthritis. Ann Rheum Dis. (2012) 71:432-9. doi: 10.1136/ard.2011.153056

167. Simma N, Bose T, Kahlfuß S, Mankiewicz J, Lowinus T, Lühder F, et al. NMDA-receptor antagonists block B-cell function but foster IL-10 production in BCR/CD40-activated B cells. Cell Commun Signal. (2014) 12:75. doi: 10.1186/s12964-014-0075-5

168. Zhang $\mathrm{Y}$, Wang Z, Xiao $\mathrm{H}$, Liu X, Zhu G, Yu D, et al. Foxd3 suppresses interleukin-10 expression in B cells. Immunology. (2017) 150:478-88. doi: 10.1111/imm.12701

169. Larsson L, Thorbert-Mros S, Rymo L, Berglundh T. Influence of epigenetic modifications of the interleukin-10 promoter on IL10 gene expression. Eur J Oral Sci. (2012) 120:14-20. doi: 10.1111/j.1600-0722.2011.00917.x

170. Zhang $\mathrm{H}$, Kuchroo V. Epigenetic and transcriptional mechanisms for the regulation of IL-10. Semin Immunol. (2019) 44:101324. doi: 10.1016/j.smim.2019.101324

171. Tonon S, Mion F, Dong J, Chang HD, Dalla E, Scapini P, et al. IL-10producing B cells are characterized by a specific methylation signature. Eur J Immunol. (2019) 49:1213-25. doi: 10.1002/eji.201848025

172. Arpaia N, Campbell C, Fan X, Dikiy S, Van Der Veeken J, Deroos P, et al. Metabolites produced by commensal bacteria promote peripheral regulatory T-cell generation. Nature. (2013) 504:451-5. doi: 10.1038/nature12726

173. Alrefai H, Muhammad K, Rudolf R, Pham DAT, Klein-Hessling S, Patra AK, et al. NFATc1 supports imiquimod-induced skin inflammation by suppressing IL-10 synthesis in B cells. Nat Commun. (2016) 7:11724. doi: $10.1038 /$ ncomms 12421
174. Bhattacharyya S, Deb J, Patra AK, Pham DAT, Chen W, Vaeth M, et al. NFATc1 affects mouse splenic B cell function by controlling the calcineurin-NFAT signaling network. J Exp Med. (2011) 208:82339. doi: 10.1084/jem.20100945

175. Cochran AG, Conery AR, Sims RJ. Bromodomains: a new target class for drug development. Nat Rev Drug Discov. (2019) 18:60928. doi: 10.1038/s41573-019-0030-7

176. Lee MB, Lee JH, Hong SH, You JS, Nam ST, Kim HW, et al. JQ1, a BET inhibitor, controls TLR4-induced IL-10 production in regulatory B cells by BRD4-NF- $\mathrm{B}$ axis. BMB Rep. (2017) 50:6406. doi: 10.5483/BMBRep.2017.50.12.194

177. Sheedy FJ. Turning 21: induction of miR-21 as a key switch in the inflammatory response. Front Immunol. (2015) 6:19. doi: 10.3389/fimmu.2015.00019

178. Wang $\mathrm{H}, \mathrm{Xu}$ W, Shao Q, Ding Q. miR-21 silencing ameliorates experimental autoimmune encephalomyelitis by promoting the differentiation of IL-10- producing B cells. Oncotarget. (2017) 8:94069-79. doi: 10.18632/oncotarget. 21578

179. Wang H, Fan H, Tao J, Shao Q, Ding Q. MicroRNA-21 silencing prolongs islet allograft survival by inhibiting Th17 cells. Int Immunopharmacol. (2019) 66:274-81. doi: 10.1016/j.intimp.2018.11.022

180. Amrouche L, You S, Sauvaget V, Manda V, Lamarthée B, Desbuissons G, et al. MicroRNA-146a-deficient mice develop immune complex glomerulonephritis. Sci Rep. (2019) 9:15597. doi: 10.1038/s41598-019-51985-1

181. Chen X, Dong S, Zhang N, Chen L, Li MG, Yang PC, et al. MicroRNA98 plays a critical role in experimental myocarditis. Int J Cardiol. (2017) 229:75-81. doi: 10.1016/j.ijcard.2016.11.263

182. Luo XQ, Yang SB, Qiu SQ, Xie R Di, Yang LT, Ke YX, et al. Posttranscriptional regulation of interleukin-10 in peripheral B cells of airway allergy patients. Am J Transl Res. (2016) 8:5766-72.

183. Huo Y, Chu Y, Guo L, Liu L, Xia X, Wang T. Cortisol is associated with low frequency of interleukin 10-producing B cells in patients with atherosclerosis. Cell Biochem Funct. (2017) 35:178-83. doi: 10.1002/cbf.3262

184. Song J, Su W, Chen X, Zhao Q, Zhang N, Li MG, et al. Micro RNA-98 suppresses interleukin-10 in peripheral B cells in patient post-cardio transplantation. Oncotarget. (2017) 8:28237-46. doi: 10.18632/oncotarget.16000

185. Zheng Y, Ge W, Ma Y, Xie G, Wang W, Han L, et al. miR-155 regulates IL-10-producing $\mathrm{CD} 24 \mathrm{hiCD} 27+\mathrm{B}$ cells and impairs their function in patients with Crohn's disease. Front Immunol. (2017) 8:914. doi: 10.3389/fimmu.2017.00914

186. Geng XR, Qiu SQ, Yang LT, Liu ZQ, Yang G, Liu JQ, et al. Allergenspecific immune response suppresses interleukin 10 expression in B cells via increasing micro-RNA-17-92 cluster. Cell Biochem Funct. (2016) 34:44954. doi: 10.1002/cbf.3207

187. Yu Z-J, Zeng L, Luo X-Q, Geng X-R, Xu R, Chen K, et al. Vitamin D3 inhibits micro RNA-17-92 to promote specific immunotherapy in allergic rhinitis. Sci Rep. (2017) 7:546. doi: 10.1038/s41598-017-0 0431-1

188. Jia X, Liu H, Xu C, Han S, Shen Y, Miao X, et al. MiR15a/16-1 deficiency induces IL-10-producing CD19 + TIM-1 + cells in tumor microenvironment. J Cell Mol Med. (2019) 23:1343-53. doi: 10.1111/jcmm.14037

189. Luo Y, Yang J, Zhang C, Jin Y, Pan H, Liu L, G, et al. Upregulation of miR-27a promotes monocyte-mediated inflammatory responses in Kawasaki disease by inhibiting function of B10 cells. J Leukoc Biol. (2020) 107:133-44. doi: 10.1002/JLB.5A0919075RR

190. Hagn M, Schwesinger E, Ebel V, Sontheimer K, Maier J, Beyer $\mathrm{T}$, et al. Human $\mathrm{B}$ cells secrete granzyme $\mathrm{B}$ when recognizing viral antigens in the context of the acute phase cytokine IL21. J Immunol. (2009) 183:1838-45. doi: 10.4049/jimmunol.09 01066

191. Kaku H, Cheng KF, Al-Abed Y, Rothstein TL. A novel mechanism of B cell-mediated immune suppression through CD73 expression and adenosine production. JImmunol. (2014) 193:5904-13. doi: 10.4049/jimmunol.1400336 
192. Saze Z, Schuler PJ, Hong CS, Cheng D, Jackson EK, Whiteside TL. Adenosine production by human $B$ cells and B cell-mediated suppression of activated $T$ cells. Blood. (2013) 122:9-18. doi: 10.1182/blood-2013-02-482406

193. Figueiró F, Muller L, Funk S, Jackson EK, Battastini AMO, Whiteside TL. Phenotypic and functional characteristics of CD39 high human regulatory B cells (Breg). Oncoimmunology. (2016) 5:e1082703. doi: 10.1080/2162402X.2015.1082703

194. Nouël A, Pochard P, Simon Q, Ségalen I, Le Meur Y, Pers JOO, et al. B-Cells induce regulatory $\mathrm{T}$ cells through TGF- $\beta / \mathrm{IDO}$ production in A CTLA-4 dependent manner. J Autoimmun. (2015) 59:53-60. doi: 10.1016/j.jaut.2015.02.004

195. Huang B, Faucette AN, Pawlitz MD, Pei B, Goyert JW, Zhou JZ, et al. Interleukin-33-induced expression of PIBF1 by decidual B cells protects against preterm labor. Nat Med. (2017) 23:128-35. doi: 10.1038/nm.4244

196. Wang L, Fu Y, Yu B, Jiang X, Liu H, Liu J, et al. HSP70, a novel regulatory molecule in B cell-mediated suppression of autoimmune diseases. J Mol Biol. (2021) 433:166634. doi: 10.1016/j.jmb.2020.08.019

197. Carter NA, Rosser EC, Mauri C. Interleukin-10 produced by B cells is crucial for the suppression of Th17/Th1 responses, induction of T regulatory type 1 cells and reduction of collagen-induced arthritis. Arthritis Res Ther. (2012) 14:R32. doi: 10.1186/ar3736

198. Xiao Z, Mohamood AS, Uddin S, Gutfreund R, Nakata C, Marshall A, et al. Inhibition of fas ligand in NOD mice unmasks a protective role for IL-10 against insulitis development. Am J Pathol. (2011) 179:72532. doi: 10.1016/j.ajpath.2011.04.016

199. Matsushita T, Horikawa M, Iwata Y, Tedder TF. Regulatory $\mathrm{B}$ cells (B10 cells) and regulatory $\mathrm{T}$ cells have independent roles in controlling experimental autoimmune encephalomyelitis initiation and late-phase immunopathogenesis. J Immunol. (2010) 185:2240-52. doi: 10.4049/jimmunol.1001307

200. Mutnal MB, Hu S, Schachtele SJ, Lokensgard JR. Infiltrating regulatory B cells control neuroinflammation following viral brain infection. J Immunol. (2014) 193:6070-80. doi: 10.4049/jimmunol.1400654

201. Korniotis S, Gras C, Letscher H, Montandon R, Mégret J, Siegert S, et al. Treatment of ongoing autoimmune encephalomyelitis with activated B-cell progenitors maturing into regulatory B cells. Nat Commun. (2016) 7:12134. doi: $10.1038 /$ ncomms 12134

202. Gao N, Dresel J, Eckstein V, Gellert R, Störch H, Venigalla RKC, et al. Impaired suppressive capacity of activation-induced regulatory B cells in systemic lupus erythematosus. Arthritis Rheumatol. (2014) 66:284961. doi: $10.1002 /$ art. 38742

203. Kleffel S, Vergani A, Tezza S, Nasr M Ben, Niewczas MA, Wong S, et al. Interleukin-10+ regulatory b cells arise within antigen-experienced CD40+ B cells to maintain tolerance to islet autoantigens. Diabetes. (2015) 64:15871. doi: $10.2337 / \mathrm{db} 13-1639$

204. Du HQ, Zhang X, An YF, Ding Y, Zhao XD. Effects of WiskottAldrich syndrome protein deficiency on IL-10-producing regulatory B cells in humans and mice. Scand J Immunol. (2015) 81:48393. doi: $10.1111 /$ sji.12282

205. Yokoyama T, Yoshizaki A, Simon KL, Kirby MR, Anderson SM, Candotti F. Age-dependent defects of regulatory B cells in wiskott-aldrich syndrome gene knockout mice. PLOS ONE. (2015) 10:e0139729. doi: 10.1371/journal.pone.0139729

206. Bouma G, Carter NA, Recher M, Malinova D, Adriani M, Notarangelo LD, et al. Exacerbated experimental arthritis in Wiskott-Aldrich syndrome protein deficiency: modulatory role of regulatory B cells. Eur J Immunol. (2014) 44:2692-702. doi: 10.1002/eji.201344245

207. Vlkova M, Ticha O, Nechvatalova J, Kalina T, Litzman J, Mauri C, et al. Regulatory B cells in CVID patients fail to suppress multifunctional IFN$\gamma+$ TNF- $\alpha+$ CD4+ T cells differentiation. Clin Immunol. (2015) 160:292300. doi: 10.1016/j.clim.2015.06.013

208. Barsotti NS, Almeida RR, Costa PR, Barros MT, Kalil J, Kokron CM. IL-10-producing regulatory $\mathrm{B}$ cells are decreased in patients with common variable immunodeficiency. PLOS ONE. (2016) 11:e0151761. doi: 10.1371/journal.pone.0151761

209. Nova-Lamperti E, Fanelli G, Becker PD, Chana P, Elgueta R, Dodd PC, et al. IL-10-produced by human transitional B-cells down-regulates CD86 expression on B-cells leading to inhibition of CD4+T-cell responses. Sci Rep. (2016) 6:20044. doi: 10.1038/srep20044

210. Gillan V, Lawrence RA, Devaney E. B cells play a regulatory role in mice infected with the L3 of Brugia pahangi. Int Immunol. (2005) 17:37382. doi: 10.1093/intimm/dxh217

211. Flores-Borja F, Bosma A, Ng D, Reddy V, Ehrenstein MR, Isenberg $\mathrm{DA}$, et al. CD19+CD24hiCD38hi B cells maintain regulatory $\mathrm{T}$ cells while limiting TH1 and TH17 differentiation. Sci Transl Med. (2013) 5:173ra23. doi: 10.1126/scitranslmed.3005407

212. Saigusa R, Winkels H, Ley K. T cell subsets and functions in atherosclerosis. Nat Rev Cardiol. (2020) 17:387-401. doi: 10.1038/s41569-020-0352-5

213. Rincón-Arévalo H, Villa-Pulgarín J, Tabares J, Rojas M, Vásquez G, RamírezPineda JR, et al. Interleukin-10 production and T cell-suppressive capacity in B cell subsets from atherosclerotic apoE -/- mice. Immunol Res. (2017) 65:995-1008. doi: 10.1007/s12026-017-8939-6

214. Ponnuswamy P, Joffre J, Herbin O, Esposito B, Laurans L, Binder CJ, et al. Angiotensin II synergizes with $\mathrm{BAFF}$ to promote atheroprotective regulatory B cells. Sci Rep. (2017) 7:4111. doi: 10.1038/s41598-017-04438-6

215. Gjurich BN, Taghavie-Moghadam PL, Ley K, Galkina EV. Lselectin deficiency decreases aortic Bla and Breg subsets and promotes atherosclerosis. Thromb Haemost. (2014) 112:80311. doi: 10.1160/TH13-10-0865

216. Cole JE, Astola N, Cribbs AP, Goddard ME, Park I, Green P, et al. Indoleamine 2,3-dioxygenase- 1 is protective in atherosclerosis and its metabolites provide new opportunities for drug development. Proc Natl Acad Sci USA. (2015) 112:13033-8. doi: 10.1073/pnas.1517820112

217. Srikakulapu P, Hu D, Yin C, Mohanta SK, Bontha SV, Peng L, et al. Artery tertiary lymphoid organs control multilayered territorialized atherosclerosis B-cell responses in Aged ApoE-/- mice. Arterioscler Thromb Vasc Biol. (2016) 36:1174-85. doi: 10.1161/ATVBAHA.115.306983

218. Liu Y, Duan WR, Liu S, Liu T, Chang YJ, Fan XM. Correlation of $\mathrm{CD} 19+\mathrm{CD} 24 \mathrm{hiCD} 38 \mathrm{hiB}$ cells in coronary artery disease with severity of atherosclerosis. Chin Med J. (2020) 133:12578. doi: 10.1097/CM9.0000000000000765

219. Rincón-Arévalo H, Quintero JC, Fortich F, Rojas M, Vásquez G, Castaño D, et al. Low frequency of IL-10+ B cells in patients with atherosclerosis is related with inflammatory condition. Heliyon. (2020) 6:e03441. doi: 10.1016/j.heliyon.2020.e03441

220. Bodhankar S, Chen Y, Vandenbark AA, Murphy SJ, Offner $H$. IL-10-producing B-cells limit CNS inflammation and infarct volume in experimental stroke. Metab Brain Dis. (2013) 28:375-86. doi: 10.1007/s11011-013-9413-3

221. Ren X, Akiyoshi K, Dziennis S, Vandenbark AA, Herson PS, Hurn $\mathrm{PD}$, et al. Regulatory B cells limit CNS inflammation and neurologic deficits in murine experimental stroke. J Neurosci. (2011) 31:855663. doi: 10.1523/JNEUROSCI.1623-11.2011

222. Chen Y, Bodhankar S, Murphy SJ, Vandenbark AA, Alkayed NJ, Offner H. Intrastriatal B-cell administration limits infarct size after stroke in B-cell deficient mice. Metab Brain Dis. (2012) 27:48793. doi: $10.1007 /$ s11011-012-9317-7

223. Bodhankar S, Chen Y, Vandenbark AA, Murphy SJ, Offner H. Treatment of experimental stroke with IL-10-producing B-cells reduces infarct size and peripheral and CNS inflammation in wild-type B-cell-sufficient mice. Metab Brain Dis. (2014) 29:59-73. doi: 10.1007/s11011-013-9474-3

224. Bodhankar S, Chen Y, Lapato A, Vandenbark AA, Murphy SJ, Saugstad JA, et al. Regulatory CD8+CD122+ T-cells predominate in CNS after treatment of experimental stroke in male mice with IL-10-secreting B-cells. Metab Brain Dis. (2015) 30:911-24. doi: 10.1007/s11011-014-9639-8

225. Wang Z, Zhou Y, Yu Y, He K, Cheng LM. Lipopolysaccharide preconditioning increased the level of regulatory $\mathrm{B}$ cells in the spleen after acute ischaemia/reperfusion in mice. Brain Res. (2018) 1701:46-57. doi: 10.1016/j.brainres.2018. 05.036

226. Wu L, Dalal R, Cao CD, Postoak JL, Yang G, Zhang Q, et al. IL-10-producing $B$ cells are enriched in murine pericardial adipose tissues and ameliorate the outcome of acute myocardial infarction. Proc Natl Acad Sci USA. (2019) 116:21673-84. doi: 10.1073/pnas.1911464116 
227. Shen L, Chng MHY, Alonso MN, Yuan R, Winer DA, Engleman EG. B-1a lymphocytes attenuate insulin resistance. Diabetes. (2015) 64:593603. doi: $10.2337 / \mathrm{db} 14-0554$

228. Wu L, Parekh VV, Hsiao J, Kitamura D, Van Kaer L. Spleen supports a pool of innate-like B cells in white adipose tissue that protects against obesityassociated insulin resistance. Proc Natl Acad Sci USA. (2014) 111:E463847. doi: 10.1073/pnas.1324052111

229. Li G, Wulan H, Song Z, Paik PA, Tsao ML, Goodman GM, et al. Regulatory B cell function is suppressed by smoking and obesity in $H$. pylori-infected subjects and is correlated with elevated risk of gastric cancer. PLOS ONE. (2015) 10:e0134591. doi: 10.1371/journal.pone.0134591

230. Jagannathan M, McDonnell M, Liang Y, Hasturk H, Hetzel J, Rubin D, et al. Toll-like receptors regulate $\mathrm{B}$ cell cytokine production in patients with diabetes. Diabetologia. (2010) 53:1461-71. doi: 10.1007/s00125-010-1730-z

231. García-Hernández MH, Rodríguez-Varela E, García-Jacobo RE, HernándezDe la Torre M, Uresti-Rivera EE, González-Amaro R, et al. Frequency of regulatory $\mathrm{B}$ cells in adipose tissue and peripheral blood from individuals with overweight, obesity and normal-weight. Obes Res Clin Pract. (2018) 12:513-9. doi: 10.1016/j.orcp.2018.07.001

232. Zhai X, Qian G, Wang Y, Chen X, Lu J, Zhang Y, et al. Elevated B cell activation is associated with type 2 diabetes development in obese subjects. Cell Physiol Biochem. (2016) 38:1257-66. doi: 10.1159/000443073

233. DeFuria J, Belkina AC, Jagannathan-Bogdan M, Snyder-Cappione J, Carr JD, Nersesova YR, et al. B cells promote inflammation in obesity and type 2 diabetes through regulation of T-cell function and an inflammatory cytokine profile. Proc Natl Acad Sci USA. (2013) 110:51338. doi: 10.1073/pnas.1215840110

234. Crouch MJ, Kosaraju R, Guesdon W, Armstrong M, Reisdorph N, Jain R, et al. Frontline science: a reduction in DHA-derived mediators in male obesity contributes toward defects in select B cell subsets and circulating antibody. $J$ Leukoc Biol. (2019) 106:241-57. doi: 10.1002/JLB.3HI1017-405RR

235. Pennati A, Ng S, Wu Y, Murphy JR, Deng J, Rangaraju S, et al. Regulatory B cells induce formation of IL-10-expressing $\mathrm{T}$ cells in mice with autoimmune neuroinflammation. J Neurosci. (2016) 36:12598610. doi: 10.1523/JNEUROSCI.1994-16.2016

236. Daien CI, Gailhac S, Mura T, Audo R, Combe B, Hahne M, et al. Regulatory B10 cells are decreased in patients with rheumatoid arthritis and are inversely correlated with disease activity. Arthritis Rheumatol. (2014) 66:2037-46. doi: 10.1002/art.38666

237. Mielle J, Audo R, Hahne M, Macia L, Combe B, Morel J, et al. IL-10 producing $\mathrm{B}$ cells ability to induce regulatory $\mathrm{T}$ cells is maintained in rheumatoid arthritis. Front Immunol. (2018) 9:961. doi: 10.3389/fimmu.2018.00961

238. Liu Y, Cheng LS, Di Wu S, Wang SQ, Li L, She WM, et al. IL-10producing regulatory B-cells suppressed effector T-cells but enhanced regulatory T-cells in chronic HBV infection. Clin Sci. (2016) 130:90719. doi: 10.1042/CS20160069

239. Matsushita T, Fujimoto M, Hasegawa M, Komura K, Takehara K, Tedder TF, et al. Inhibitory role of CD19 in the progression of experimental autoimmune encephalomyelitis by regulating cytokine response. Am J Pathol. (2006) 168:812-21. doi: 10.2353/ajpath.2006.050923

240. Hsieh J, Williams P, Rafei M, Birman E, Cuerquis J, Yuan S, et al. Inducible IL10 suppressor B cells inhibit CNS inflammation and T helper 17 polarization. Mol Ther. (2012) 20:1767-77. doi: 10.1038/mt.2012.127

241. Hong C, Zhang T, Gao XM. Recombinant murine calreticulin fragment 39-272 expands CD1dhiCD5+ IL-10-secreting B cells that modulate experimental autoimmune encephalomyelitis in C57BL/6 mice. Mol Immunol. (2013) 55:237-46. doi: 10.1016/j.molimm.2013.02.003

242. Hernandez HJ, Wang Y, Stadecker MJ. In Infection with Schistosoma mansoni, B cells are required for T helper type 2 cell responses but not for granuloma formation. J Immunol. (1997) 158:4832-7.

243. Palanivel V, Posey C, Horauf AM, Solbach W, Piessens WF, Harn DA. B-cell outgrowth and ligand-specific production of IL-10 correlate with Th2 dominance in certain parasitic diseases. Exp Parasitol. (1996) 84:16877. doi: 10.1006/expr.1996.0102

244. Ronet C, Torre YH-L, Revaz-Breton M, Mastelic B, Tacchini-Cottier F, Louis J, et al. Regulatory B cells shape the development of Th2 immune responses in $\mathrm{BALB} / \mathrm{c}$ mice infected with leishmania major through IL-10 production. $J$ Immunol. (2010) 184:886-94. doi: 10.4049/jimmunol.0901114
245. Jeong Y-I, Hong S-H, Cho S-H, Lee W-J, Lee S-E. Induction of IL-10producing CD1dhighCD5+ regulatory B cells following Babesia microtiInfection. PLoS ONE. (2012) 7:e46553. doi: 10.1371/journal.pone.0046553

246. Il Jeong Y, Hong SH, Cho SH, Park MY, Lee SE. Induction of IL-10producing regulatory B cells following Toxoplasma gondii infection is important to the cyst formation. Biochem Biophys Reports. (2016) 7:917. doi: 10.1016/j.bbrep.2016.05.008

247. van der Vlugt LEPM, Labuda LA, Ozir-Fazalalikhan A, Lievers E, Gloudemans AK, Liu K-Y, et al. Schistosomes induce regulatory features in human and mouse CD1dhi B cells: inhibition of allergic inflammation by IL-10 and regulatory T cells. PLoS ONE. (2012) 7:e30883. doi: 10.1371/journal.pone.0030883

248. Van Der Vlugt LEPM, Zinsou JF, Ozir-Fazalalikhan A, Kremsner PG, Yazdanbakhsh M, Adegnika AA, et al. Interleukin 10 (IL-10)producing CD1dhi regulatory B cells from Schistosoma haematobiuminfected individuals induce IL-10-positive T cells and suppress effector T-cell cytokines. J Infect Dis. (2014) 210:1207-16. doi: 10.1093/infdis/jiu257

249. Correale J, Farez M, Razzitte G. Helminth infections associated with multiple sclerosis induce regulatory B cells. Ann Neurol. (2008) 64:18799. doi: 10.1002/ana.21438

250. Mangan NE, van Rooijen N, McKenzie ANJ, Fallon PG. Helminthmodified pulmonary immune response protects mice from allergen-induced airway hyperresponsiveness. J Immunol. (2006) 176:138-47. doi: 10.4049/jimmunol.176.1.138

251. Amu S, Saunders SP, Kronenberg M, Mangan NE, Atzberger A, Fallon PG. Regulatory B cells prevent and reverse allergic airway inflammation via FoxP3-positive T regulatory cells in a murine model. J Allergy Clin Immunol. (2010) 125:1114-24.e8. doi: 10.1016/j.jaci.2010.01.018

252. Smits HH, Hammad $H$, van Nimwegen M, Soullie T, Willart MA, Lievers E, et al. Protective effect of Schistosoma mansoni infection on allergic airway inflammation depends on the intensity and chronicity of infection. J Allergy Clin Immunol. (2007) 120:932-40. doi: 10.1016/j.jaci.2007.06.009

253. Jeong Y Il, Hong SH, Cho SH, Lee WJ, Lee SE. Toxoplasma gondii infection suppresses house dust mite extract-induced atopic dermatitis in NC/Nga mice. Allergy Asthma Immunol Res. (2015) 7:557-64. doi: 10.4168/aair.2015.7.6.557

254. Gao X, Ren X, Wang Q, Yang Z, Li Y, Su Z, et al. Critical roles of regulatory $\mathrm{B}$ and $\mathrm{T}$ cells in helminth parasite-induced protection against allergic airway inflammation. Clin Exp Immunol. (2019) 198:390402. doi: $10.1111 /$ cei. 13362

255. Kim A-R, Kim HS, Kim DK, Nam ST, Kim HW, Park YH, et al. Mesenteric IL-10-producing $\mathrm{CD} 5+$ regulatory $\mathrm{B}$ cells suppress cow's milk casein-induced allergic responses in mice. Sci Rep. (2016) 6:19685. doi: $10.1038 /$ srep 19685

256. Zissler UM, Jakwerth CA, Guerth FM, Pechtold L, Aguilar-Pimentel JA, Dietz K, et al. Early IL-10 producing B-cells and coinciding Th/Tr17 shifts during three year grass-pollen AIT. EBioMedicine. (2018) 36:47588. doi: 10.1016/j.ebiom.2018.09.016

257. Boonpiyathad T, van de Veen W, Wirz O, Sokolowska M, Rückert B, Tan G, et al. Role of Der p 1-specific B cells in immune tolerance during 2 years of house dust mite-specific immunotherapy. J Allergy Clin Immunol. (2019) 143:1077-86.e10. doi: 10.1016/j.jaci.2018.10.061

258. Braza F, Chesne J, Durand M, Dirou S, Brosseau C, Mahay G, et al. A regulatory $\mathrm{CD} 9+\mathrm{B}$-cell subset inhibits HDM-induced allergic airway inflammation. Allergy Eur J Allergy Clin Immunol. (2015) 70:142131. doi: 10.1111/all.12697

259. Khan AR, Amu S, Saunders SP, Hams E, Blackshields G, Leonard MO, et al. Ligation of TLR7 on CD19+CD1dhi B cells suppresses allergic lung inflammation via regulatory T cells. Eur J Immunol. (2015) 45:184254. doi: 10.1002/eji.201445211

260. Habener A, Happle C, Grychtol R, Skuljec J, Busse M, Dalüge K, et al. Regulatory B cells control airway hyperreactivity and lung remodeling in a murine asthma model. J Allergy Clin Immunol. (2020). doi: 10.1016/j.jaci.2020.09.041. [Epub ahead of print].

261. Xue D, Kaufman GN, Dembele M, Beland M, Massoud AH, Mindt BC, et al. Semaphorin $4 \mathrm{C}$ protects against allergic inflammation: requirement of regulatory CD138 + plasma cells. J Immunol. (2017) 198:7181. doi: 10.4049/jimmunol.1600831 
262. Weber M, Stein P, Prüfer S, Rudolph B, Kreft A, Schmitt E, et al. Donor and host B cell-derived IL-10 contributes to suppression of graft-versus-host disease. Eur J Immunol. (2014) 44:1857-65. doi: 10.1002/eji.201344081

263. Rowe V, Banovic T, MacDonald KP, Kuns R, Don AL, Morris ES, et al. Host B cells produce IL-10 following TBI and attenuate acute GVHD after allogeneic bone marrow transplantation. Blood. (2006) 108:248592. doi: 10.1182/blood-2006-04-016063

264. Park M-J, Baek J-A, Kim S-Y, Jung K-A, Choi JW, Park S-H, et al. Myeloidderived suppressor cells therapy enhance immunoregulatory properties in acute graft versus host disease with combination of regulatory T cells. J Transl Med. (2020) 18:483. doi: 10.1186/s12967-020-02657-6

265. Sarvaria A, Basar R, Mehta RS, Shaim H, Muftuoglu M, Khoder A, et al. IL-10+ regulatory B cells are enriched in cord blood and may protect against cGVHD after cord blood transplantation. Blood. (2016) 128:134661. doi: 10.1182/blood-2016-01-695122

266. Khoder A, Sarvaria A, Alsuliman A, Chew C, Sekine T, Cooper N, et al. Regulatory B cells are enriched within the IgM memory and transitional subsets in healthy donors but are deficient in chronic GVHD. Blood. (2014) 124:2034-45. doi: 10.1182/blood-2014-04-571125

267. Alhabbab R, Blair P, Smyth LA, Ratnasothy K, Peng Q, Moreau A, et al. Galectin-1 is required for the regulatory function of B cells. Sci Rep. (2018) 8:2725. doi: 10.1038/s41598-018-19965-Z

268. Lal G, Kulkarni N, Nakayama Y, Singh AK, Sethi A, Burrell BE, et al. IL10 from marginal zone precursor B cells controls the differentiation of Th17, Tfh and Tfr cells in transplantation tolerance. Immunol Lett. (2016) 170:52-63. doi: 10.1016/j.imlet.2016.01.002

269. Lal G, Nakayama Y, Sethi A, Singh AK, Burrell BE, Kulkarni N, et al. Interleukin-10 from marginal zone precursor B-cell subset is required for costimulatory blockade-induced transplantation tolerance. Transplantation. (2015) 99:1817-28. doi: 10.1097/TP.0000000000000718

270. Shabir S, Girdlestone J, Briggs D, Kaul B, Smith H, Daga S, et al. Transitional B lymphocytes are associated with protection from kidney allograft rejection: a prospective study. Am J Transplant. (2015) 15:138491. doi: $10.1111 /$ ajt.13122

271. Nouël A, Ségalen I, Jamin C, Doucet L, Caillard S, Renaudineau Y, et al. B cells display an abnormal distribution and an impaired suppressive function in patients with chronic antibody-mediated rejection. Kidney Int. (2014) 85:590-9. doi: 10.1038/ki.2013.457

272. Svachova V, Sekerkova A, Hruba P, Tycova I, Rodova M, Cecrdlova E, et al. Dynamic changes of B-cell compartments in kidney transplantation: lack of transitional B cells is associated with allograft rejection. Transpl Int. (2016) 29:540-8. doi: 10.1111/tri.12751

273. Brosseau C, Danger R, Durand M, Durand E, Foureau A, Lacoste P, et al. Blood CD9+ B cell, a biomarker of bronchiolitis obliterans syndrome after lung transplantation. Am J Transplant. (2019) 19:3162-75. doi: $10.1111 /$ ajt.15532

274. Cherukuri A, Rothstein DM, Clark B, Carter CR, Davison A, HernandezFuentes $\mathrm{M}$, et al. Immunologic human renal allograft injury associates with an altered IL-10/TNF- $\alpha$ expression ratio in regulatory B cells. J Am Soc Nephrol. (2014) 25:1575-85. doi: 10.1681/ASN.2013080837

275. Cherukuri A, Salama AD, Carter CR, Landsittel D, Arumugakani G, Clark $\mathrm{B}$, et al. Reduced human transitional B cell T1/T2 ratio is associated with subsequent deterioration in renal allograft function. Kidney Int. (2017) 91:183-95. doi: 10.1016/j.kint.2016.08.028

276. Newell KA, Asare A, Kirk AD, Gisler TD, Bourcier K, Suthanthiran M, et al. Identification of a $B$ cell signature associated with renal transplant tolerance in humans. J Clin Invest. (2010) 120:1836-47. doi: 10.1172/JCI39933

277. Sagoo P, Perucha E, Sawitzki B, Tomiuk S, Stephens DA, Miqueu P, et al. Development of a cross-platform biomarker signature to detect renal transplant tolerance in humans. J Clin Invest. (2010) 120:184861. doi: $10.1172 /$ JCI39922

278. Silva HM, Takenaka MCS, Moraes-Vieira PMM, Monteiro SM, Hernandez MO, Chaara W, et al. Preserving the B-cell compartment favors operational tolerance in human renal transplantation. Mol Med. (2012) 18:73343. doi: 10.2119/molmed.2011.00281

279. Chesneau M, Pallier A, Braza F, Lacombe G, Le Gallou S, Baron D, et al. Unique B cell differentiation profile in tolerant kidney transplant patients. Am J Transplant. (2014) 14:144-55. doi: 10.1111/ajt.12508
280. Nova-Lamperti E, Chana P, Mobillo P, Runglall M, Kamra Y, McGregor $\mathrm{R}$, et al. Increased CD40 ligation and reduced bcr signalling leads to higher il-10 production in b cells from tolerant kidney transplant patients. Transplantation. (2017) 101:541-7. doi: 10.1097/TP.0000000000001341

281. Jensen F, Muzzio D, Soldati R, Fest S, Zenclussen AC. Regulatory B10 cells restore pregnancy tolerance in a mouse model. Biol Reprod. (2013) 89:90. doi: 10.1095/biolreprod.113.110791

282. Schumacher A, Ehrentraut S, Scharm M, Wang H, Hartig R, Morse HC, et al. Plasma cell alloantigen 1 and IL-10 secretion define two distinct peritoneal B1a B cell subsets with opposite functions, PC1high cells being protective and PCllow cells harmful for the growing fetus. Front Immunol. (2018) 9:1045. doi: 10.3389/fimmu.2018.01045

283. Guzman-Genuino RM, Eldi P, Garcia-Valtanen P, Hayball JD, Diener KR. Uterine B cells exhibit regulatory properties during the periimplantation stage of murine pregnancy. Front Immunol. (2019) 10:2899. doi: 10.3389/fimmu.2019.02899

284. Koushaeian L, Ghorbani F, Ahmadi M, Eghbal-Fard S, Zamani M, Danaii $\mathrm{S}$, et al. The role of IL-10-producing B cells in repeated implantation failure patients with cellular immune abnormalities. Immunol Lett. (2019) 214:16-22. doi: 10.1016/j.imlet.2019.08.002

285. Fröhlich C, Ehrhardt J, Krüger D, Trojnarska D, Zygmunt M, Muzzio DO. Pregnancy status alters IL-21-mediated effects on murine B lymphocytes. Reproduction. (2020) 159:351-9. doi: 10.1530/REP-19-0407

286. Lima J, Martins C, Leandro MJ, Nunes G, Sousa M-J, Branco JC, et al. Characterization of $\mathrm{B}$ cells in healthy pregnant women from late pregnancy to post-partum: a prospective observational study. $B M C$ Pregnancy Childbirth. (2016) 16:139. doi: 10.1186/s12884-016-0927-7

287. Busse M, Campe K-NJ, Redlich A, Oettel A, Hartig R, Costa S-D, et al. Regulatory B cells are decreased and impaired in their function in peripheral maternal blood in pre-term birth. Front Immunol. (2020) 11:386. doi: 10.3389/fimmu.2020.00386

288. Danaii S, Ghorbani F, Ahmadi M, Abbaszadeh H, Koushaeian L, SoltaniZangbar MS, et al. IL-10-producing B cells play important role in the pathogenesis of recurrent pregnancy loss. Int Immunopharmacol. (2020) 87:106806. doi: 10.1016/j.intimp.2020.106806

289. Benner M, Feyaerts D, García CC, Inci N, López SC, Fasse E, et al. Clusters of tolerogenic $\mathrm{B}$ cells feature in the dynamic immunological landscape of the pregnant uterus. Cell Rep. (2020) 32:108204. doi: 10.1016/j.celrep.2020.108204

290. Busse M, Campe K-NJ, Nowak D, Schumacher A, Plenagl S, Langwisch S, et al. IL-10 producing B cells rescue mouse fetuses from inflammation-driven fetal death and are able to modulate T cell immune responses. Sci Rep. (2019) 9:9335. doi: 10.1038/s41598-019-45860-2

291. Yu J, Duong VHH, Westphal K, Westphal A, Suwandi A, Grassl GA, et al. Surface receptor Toso controls B cell-mediated regulation of $\mathrm{T}$ cell immunity. J Clin Invest. (2018) 128:1820-36. doi: 10.1172/JCI97280

292. Siewe B, Stapleton JT, Martinson J, Keshavarzian A, Kazmi N, Demarais PM, et al. Regulatory B cell frequency correlates with markers of HIV disease progression and attenuates anti-HIV CD8 $+\mathrm{T}$ cell function in vitro. J Leukoc Biol. (2013) 93:811-8. doi: 10.1189/jlb.0912436

293. Liu J, Zhan W, Kim CJ, Clayton K, Zhao H, Lee E, et al. IL-10-producing B cells are induced early in HIV-1 infection and suppress HIV-1-specific T cell responses. PLoS ONE. (2014) 9:e89236. doi: 10.1371/journal.pone.0089236

294. Das A, Ellis G, Pallant C, Lopes AR, Khanna P, Peppa D, et al. IL-10producing regulatory $\mathrm{B}$ cells in the pathogenesis of chronic hepatitis $\mathrm{B}$ virus infection. J Immunol. (2012) 189:3925-35. doi: 10.4049/jimmunol.1103139

295. Liu M, Chen HY, Luo L, Wang Y, Zhang D, Song N, et al. Neutralization of IL-10 produced by $\mathrm{B}$ cells promotes protective immunity during persistent HCV infection in humanized mice. Eur J Immunol. (2020) 50:135061. doi: $10.1002 /$ eji.201948488

296. Siewe B, Wallace J, Rygielski S, Stapleton JT, Martin J, Deeks SG, et al. Regulatory B cells inhibit cytotoxic T lymphocyte (CTL) activity and elimination of infected CD4 T cells after in vitro reactivation of HIV latent reservoirs. PLoS ONE. (2014) 9:e92934. doi: 10.1371/journal.pone.00 92934

297. Chen M, Zhang L, Ren Y, Zhang K, Yang Y, Fang Y, et al. Defective function of CD24+CD38+ regulatory B cells in ankylosing spondylitis. DNA Cell Biol. (2016) 35:88-95. doi: 10.1089/dna.2015.3046 
298. Choe J, Choi YS. IL-10 interrupts memory B cell expansion in the germinal center by inducing differentiation into plasma cells. Eur J Immunol. (1998) 28:508-15. doi: 10.1002/(SICI)1521-4141(199802)28:02<508::AIDIMMU508>3.0.CO;2-I

299. Levy Y, Brouet JC. Interleukin-10 prevents spontaneous death of germinal center B cells by induction of the bcl-2 protein. J Clin Invest. (1994) 93:4248. doi: 10.1172/JCI116977

300. Rousset F, Garcia E, Defrance T, Peronne C, Vezzio N, Hsu DH, et al. Interleukin 10 is a potent growth and differentiation factor for activated human B lymphocytes. Proc Natl Acad Sci USA. (1992) 89:18903. doi: $10.1073 /$ pnas. 89.5 .1890

301. Defrance T, Vanbervliet B, Brière F, Durand I, Rousset F, Banchereau J. Interleukln 10 and transforming growth factor $\beta$ cooperate to induce antiCD40-activated naive human B cells to secrete immunoglobulin A. J Exp Med. (1992) 175:671-82. doi: 10.1084/jem.175.3.671

302. Burdin N, Van Kooten C, Galibert L, Abrams JS, Wijdenes J, Banchereau J, et al. Endogenous IL-6 and IL-10 contribute to the differentiation of CD40- activated human B lymphocytes. J Immunol. (1995) 154:2533-44.

303. Horikawa M, Minard-Colin V, Matsushita T, Tedder TF. Regulatory B cell production of IL-10 inhibits lymphoma depletion during CD20 immunotherapy in mice. J Clin Invest. (2011) 121:4268-80. doi: 10.1172/JCI59266

304. Sindhava V, Woodman ME, Stevenson B, Bondada S. Interleukin-10 mediated autoregulation of murine B-1 B-cells and its role in Borrelia hermsii infection. PLoS ONE. (2010) 5:e11445. doi: 10.1371/journal.pone.0011445

305. Hoyt TR, Dobrinen E, Kochetkova I, Meissner N. B cells modulate systemic responses to Pneumocystis Murina lung infection and protect on-demand hematopoiesis via $\mathrm{T}$ cell-independent innate mechanisms when type I interferon signaling is absent. Infect Immun. (2015) 83:74358. doi: 10.1128/IAI.02639-14

306. Sun CM, Deriaud E, Leclerc C, Lo-Man R. Upon TLR9 signaling, CD5+ B cells control the IL-12-dependent Th1-priming capacity of neonatal DCs. Immunity. (2005) 22:467-77. doi: 10.1016/j.immuni.2005.02.008

307. Boldison J, Da Rosa LC, Davies J, Wen L, Wong FS. Dendritic cells license regulatory $\mathrm{B}$ cells to produce $\mathrm{IL}-10$ and mediate suppression of antigen-specific CD8 T cells. Cell Mol Immunol. (2020) 17:84355. doi: 10.1038/s41423-019-0324-z

308. Maerz JK, Trostel C, Lange A, Parusel R, Michaelis L, Schäfer A, et al. Bacterial immunogenicity is critical for the induction of regulatory B cells in suppressing inflammatory immune responses. Front Immunol. (2019) 10:3093. doi: 10.3389/fimmu.2019.03093

309. Horikawa M, Weimer ET, DiLillo DJ, Venturi GM, Spolski R, Leonard WJ, et al. Regulatory B cell (B10 cell) expansion during Listeria infection governs innate and cellular immune responses in mice. J Immunol. (2013) 190:1158-68. doi: 10.4049/jimmunol.1201427

310. Liu D, Yin X, Olyha SJ, Nascimento MSL, Chen P, White T, et al. IL-10dependent crosstalk between murine marginal zone B cells, macrophages, and CD8 $\alpha+$ dendritic cells promotes listeria monocytogenes infection. Immunity. (2019) 51:64-76.e7. doi: 10.1016/j.immuni.2019.05.011

311. Stanic B, Van De Veen W, Wirz OF, Rückert B, Morita H, Söllner S, et al. IL10-overexpressing B cells regulate innate and adaptive immune responses. J Allergy Clin Immunol. (2015) 135:771-80.e8. doi: 10.1016/j.jaci.2014.07.041

312. Monach PA, Schreiber H, Rowley DA. CD4+ and B lymphocytes in transplantation immunity: II. Augmented rejection of tumor allografts by mice lacking B cells. Transplantation. (1993) 55:1356-61. doi: 10.1097/00007890-199306000-00027

313. Shah S, Divekar AA, Hilchey SP, Cho HM, Newman CL, Shin SU, et al. Increased rejection of primary tumors in mice lacking B cells: inhibition of anti-tumor CTL and TH1 cytokine responses by B cells. Int J Cancer. (2005) 117:574-86. doi: 10.1002/ijc.21177

314. Qin Z, Richter G, Schüler T, Ibe S, Cao X, Blankenstein T. B cells inhibit induction of T cell-dependent tumor immunity. Nat Med. (1998) 4:62730. doi: $10.1038 / \mathrm{nm} 0598-627$

315. Inoue $\mathrm{S}$, Leitner $\mathrm{WW}$, Golding $\mathrm{B}$, Scott D. Inhibitory effects of B cells on antitumor immunity. Cancer Res. (2006) 66:77417. doi: 10.1158/0008-5472.CAN-05-3766
316. Kim S, Fridlender ZG, Dunn R, Kehry MR, Kapoor V, Blouin A, et al. Bcell depletion using an anti-CD20 antibody augments antitumor immune responses and immunotherapy in nonhematopoetic murine tumor models. $J$ Immunother. (2008) 31:446-57. doi: 10.1097/CJI.0b013e31816d1d6a

317. Wei X, Jin Y, Tian Y, Zhang H, Wu J, Lu W, et al. Regulatory B cells contribute to the impaired antitumor immunity in ovarian cancer patients. Tumor Biol. (2016) 37:6581-8. doi: 10.1007/s13277-015-4538-0

318. Chen Z, Zhu Y, Du R, Pang N, Zhang F, Dong D, et al. Role of regulatory B cells in the progression of cervical cancer. Mediators Inflamm. (2019) 2019:1-8. doi: 10.1155/2019/6519427

319. Hetta HF, Mekky MA, Zahran AM, Abdel-Malek MO, Ramadan HK, Shafik EA, et al. Regulatory b cells and their cytokine profile in HCV-related hepatocellular carcinoma: association with regulatory $\mathrm{t}$ cells and disease progression. Vaccines. (2020) 8:1-12. doi: 10.3390/vaccines 8030380

320. Cai C, Zhang J, Li M, Wu ZJ, Song KH, Zhan TW, et al. Interleukin 10expressing B cells inhibit tumor-infiltrating $\mathrm{T}$ cell function and correlate with T cell Tim-3 expression in renal cell carcinoma. Tumor Biol. (2016) 37:8209-18. doi: 10.1007/s13277-015-4687-1

321. Wang X, Li J, Lu C, Wang G, Wang Z, Liu X, et al. IL-10-producing $B$ cells in differentiated thyroid cancer suppress the effector function of $\mathrm{T}$ cells but improve their survival upon activation. Exp Cell Res. (2019) 376:192-7. doi: 10.1016/j.yexcr.2019.01.021

322. Zhou X, Su YX, Lao XM, Liang YJ, Liao GQ. CD19+IL-10+ regulatory B cells affect survival of tongue squamous cell carcinoma patients and induce resting CD4+ T cells to CD4+Foxp3+ regulatory T cells. Oral Oncol. (2016) 53:27-35. doi: 10.1016/j.oraloncology.2015.11.003

323. Mao H, Pan F, Wu Z, Wang Z, Zhou Y, Zhang P, et al. Colorectal tumors are enriched with regulatory plasmablasts with capacity in suppressing T cell inflammation. Int Immunopharmacol. (2017) 49:95101. doi: 10.1016/j.intimp.2017.05.018

324. Zhou M, Wen Z, Cheng F, Ma J, Li W, Ren H, et al. Tumor-released autophagosomes induce IL-10-producing B cells with suppressive activity on T lymphocytes via TLR2-MyD88-NF-КB signal pathway. Oncoimmunology. (2016) 5:e1180485. doi: 10.1080/2162402X.2016.1180485

325. Chen Y-Q, Li P-C, Pan N, Gao R, Wen Z-F, Zhang T-Y, et al. Tumor-released autophagosomes induces $\mathrm{CD} 4+\mathrm{T}$ cell-mediated immunosuppression via a TLR2-IL-6 cascade. J Immunother Cancer. (2019) 7:178. doi: 10.1186/s40425-019-0646-5

326. Zhang Y, Pan N, Sheng Y, Zhou M, Wen Z, Chen Y, et al. Hypoxia enhances IL-10-producing B cell generation through upregulating highmobility group B1 on tumor cell-released autophagosomes. Immunol Lett. (2019) 216:36-42. doi: 10.1016/j.imlet.2019.09.005

327. Mao Y, Wang Y, Dong L, Zhang Q, Wang C, Zhang Y, et al. Circulating exosomes from esophageal squamous cell carcinoma mediate the generation of B10 and PD-1high Breg cells. Cancer Sci. (2019) 110:270010. doi: $10.1111 /$ cas. 14122

328. Mao H, Pan F, Wu Z, Wang Z, Zhou Y, Zhang P, et al. CD19 Plasmablasts suppress harmful Th17 inflammation through interleukin 10 pathway in colorectal cancer. DNA Cell Biol. (2017) 36:870-7. doi: 10.1089/dna.2017.3814

329. Zhang L, Tai Y-T, Ho M, Xing L, Chauhan D, Gang A, et al. Regulatory B cell-myeloma cell interaction confers immunosuppression and promotes their survival in the bone marrow milieu. Blood Cancer J. (2017) 7:e547. doi: 10.1038/bcj.2017.24

330. Zhao R, Liu M, Li X, Chen H, Deng J, Huang C, et al. A strategy of targeting B10 cell by CD19scFv-IL10R for tumor therapy. Biochem Biophys Res Commun. (2018) 506:990-6. doi: 10.1016/j.bbrc.2018.10.191

331. Manna A, Kellett T, Aulakh S, Lewis-Tuffin LJ, Dutta N, Knutson K, et al. Targeting CD38 is lethal to Breg-like chronic lymphocytic leukemia cells and Tregs, but restores CD81 T-cell responses. Blood Adv. (2020) 4:214357. doi: 10.1182/bloodadvances. 2019001091

332. Li MO, Wan YY, Sanjabi S, Robertson AKL, Flavell RA. Transforming growth factor- $\beta$ regulation of immune responses. Annu Rev Immunol. (2006) 24:99-146. doi: 10.1146/annurev.immunol.24.021605.090737

333. Kehrl JH, Roberts AB, Wakefield LM, Jakowlew S, Sporn MB, Fauci AS. Transforming growth factor beta is an important immunomodulatory protein for human B lymphocytes. J Immunol. (1986) 137:3855-60. 
334. Snir A, Kessel A, Haj T, Rosner I, Slobodin G, Toubi E. Anti-IL-6 receptor antibody (tocilizumab): a B cell targeting therapy. Clin Exp Rheumatol. (2011) 29:697-700. doi: 10.1136/ard.2010.149005.1

335. Joly MS, Martin RP, Mitra-Kaushik S, Phillips L, D’Angona A, Richards SM, et al. Transient low-dose methotrexate generates b regulatory cells that mediate antigen-specific tolerance to alglucosidase alfa. J Immunol. (2014) 193:3947-58. doi: 10.4049/jimmunol.1303326

336. Chen WJ, Jin W, Hardegen N, Lei KJ, Li L, Marinos N, et al. Conversion of peripheral CD4+CD25- naive $\mathrm{T}$ cells to $\mathrm{CD} 4+\mathrm{CD} 25+$ regulatory $\mathrm{T}$ cells by TGF- $\beta$ induction of transcription factor Foxp3. J Exp Med. (2003) 198:1875-86. doi: 10.1084/jem.20030152

337. Shah S, Qiao L. Resting B cells expand a CD4+CD25+Foxp3+ Treg population via TGF- $\beta 3$. Eur J Immunol. (2008) 38:248898. doi: 10.1002/eji.200838201

338. Lee KM, Stott RT, Zhao G, Soohoo J, Xiong W, Lian MM, et al. TGF- $\beta$-producing regulatory $\mathrm{B}$ cells induce regulatory $\mathrm{T}$ cells and promote transplantation tolerance. Eur J Immunol. (2014) 44:172836. doi: 10.1002/eji.201344062

339. Singh A, Carson WF, Secor ER, Guernsey LA, Flavell RA, Clark RB, et al. Regulatory role of $\mathrm{B}$ cells in a murine model of allergic airway disease. $J$ Immunol. (2008) 180:7318-26. doi: 10.4049/jimmunol.180.11.7318

340. Liu ZQ, Wu Y, Song JP, Liu X, Liu Z, Zheng PY, et al. Tolerogenic CX3CR1+ B cells suppress food allergy-induced intestinal inflammation in mice. Allergy Eur J Allergy Clin Immunol. (2013) 68:1241-8. doi: 10.1111/all.12218

341. Wang W, Yuan X, Chen H, Xie G, Ma Y, Zheng Y, et al. CD19+CD24hiCD38hi Bregs involved in downregulate helper $\mathrm{T}$ cells and upregulate regulatory $\mathrm{T}$ cells in gastric cancer. Oncotarget. (2015) 6:33486-99. doi: 10.18632/oncotarget.5588

342. Lee-Chang C, Bodogai M, Martin-Montalvo A, Wejksza K, Sanghvi M, Moaddel R, et al. Inhibition of breast cancer metastasis by resveratrolmediated inactivation of tumor-evoked regulatory B cells. J Immunol. (2013) 191:4141-51. doi: 10.4049/jimmunol.1300606

343. Premkumar K, Shankar BS. TGF- $\beta$ R inhibitor SB431542 restores immune suppression induced by regulatory B-T cell axis and decreases tumour burden in murine fibrosarcoma. Cancer Immunol Immunother. (2021) 70:153-68. doi: 10.1007/s00262-020-02666-w

344. Olkhanud PB, Baatar D, Bodogai M, Hakim F, Gress R, Anderson RL, et al. Breast cancer lung metastasis requires expression of chemokine receptor CCR4 and regulatory T cells. Cancer Res. (2009) 69:59966004. doi: 10.1158/0008-5472.CAN-08-4619

345. Wejksza K, Lee-Chang C, Bodogai M, Bonzo J, Gonzalez FJ, Lehrmann $\mathrm{E}$, et al. Cancer-produced metabolites of 5-lipoxygenase induce tumorevoked regulatory B cells via peroxisome proliferator-activated receptor $\alpha$. J Immunol. (2013) 190:2575-84. doi: 10.4049/jimmunol.1201920

346. Bodogai M, Moritoh K, Lee-Chang C, Hollander CM, ShermanBaust CA, Wersto RP, et al. Immunosuppressive and prometastatic functions of myeloid-derived suppressive cells rely upon education from tumor-associated B cells. Cancer Res. (2015) 75:3456-65. doi: 10.1158/0008-5472.CAN-14-3077

347. Song J, Chen X, Wang M, Xing Y, Zheng Z, Hu S. Cardiac endothelial cell-derived exosomes induce specific regulatory B cells. Sci Rep. (2015) 4:7583. doi: 10.1038/srep07583

348. Parekh VV, Prasad DVR, Banerjee PP, Joshi BN, Kumar A, Mishra GC. B cells activated by lipopolysaccharide, but not by anti-Ig and anti-CD40 antibody, induce anergy in CD8 + T cells: role of TGF- $\beta 1$. J Immunol. (2003) 170:5897-911. doi: 10.4049/jimmunol.170.12.5897

349. Bjarnadóttir K, Benkhoucha M, Merkler D, Weber MS, Payne NL, Bernard CCA, et al. B cell-derived transforming growth factor- $\beta 1$ expression limits the induction phase of autoimmune neuroinflammation. Sci Rep. (2016) 6:34594. doi: 10.1038/srep34594

350. Reyes JL, Wang A, Fernando MR, Graepel R, Leung G, van Rooijen N, et al. Splenic B cells from hymenolepis diminuta- infected mice ameliorate colitis independent of $\mathrm{T}$ cells and via cooperation with macrophages. J Immunol. (2015) 194:364-78. doi: 10.4049/jimmunol.1400738

351. Guo Y, Zhang X, Qin M, Wang X. Changes in peripheral CD19+Foxp3+ and $\mathrm{CD} 19+\mathrm{TGF} \beta+$ regulatory B cell populations in rheumatoid arthritis patients with interstitial lung disease. J Thorac Dis. (2015) 7:471-7. doi: 10.3978/j.issn.2072-1439.2015.02.11
352. Karim MR, Zhang H-Y, Yuan J, Sun Q, Wang Y-F. Regulatory B cells in seropositive myasthenia gravis versus healthy controls. Front Neurol. (2017) 8:43. doi: 10.3389/fneur.2017.00043

353. Natarajan P, Singh A, McNamara JT, Secor ER, Guernsey LA, et al. Regulatory B cells from hilar lymph nodes of tolerant mice in a murine model of allergic airway disease are $\mathrm{CD} 5+$, express TGF- $\beta$, and colocalize with CD4+ Foxp3+ T cells. Mucosal Immunol. (2012) 5:691701. doi: 10.1038/mi.2012.42

354. Collison LW, Workman CJ, Kuo TT, Boyd K, Wang Y, Vignali KM, et al. The inhibitory cytokine IL-35 contributes to regulatory T-cell function. Nature. (2007) 450:566-9. doi: 10.1038/nature06306

355. Collison LW, Chaturvedi V, Henderson AL, Giacomin PR, Guy C, Bankoti J, et al. IL-35-mediated induction of a potent regulatory T cell population. Nat Immunol. (2010) 11:1093-101. doi: 10.1038/ni.1952

356. Yu CR, Choi JK, Uche AN, Egwuagu CE. Production of IL-35 by Bregs is mediated through binding of BATF-IRF-4-IRF-8 complex to il12a and ebi3 promoter elements. J Leukoc Biol. (2018) 104:114757. doi: 10.1002/JLB.3A0218-071RRR

357. Chen $\mathrm{C}, \mathrm{Xu} \mathrm{H}$, Peng Y, Luo H, Huang G-X, Wu X-J, et al. Elevation in the counts of IL-35-producing B cells infiltrating into lung tissue in mycobacterial infection is associated with the downregulation of Th1/Th17 and upregulation of Foxp3+Treg. Sci Rep. (2020) 10:13212. doi: 10.1038/s41598-020-69984-y

358. Dambuza IM, He C, Choi JK, Yu C-R, Wang R, Mattapallil MJ, et al. IL-12p35 induces expansion of IL-10 and IL-35-expressing regulatory B cells and ameliorates autoimmune disease. Nat Commun. (2017) 8:719. doi: 10.1038/s41467-017-00838-4

359. Takahashi R, MacChini M, Sunagawa M, Jiang Z, Tanaka T, Valenti $\mathrm{G}$, et al. Interleukin- $\beta$-induced pancreatitis promotes pancreatic ductal adenocarcinoma via B lymphocyte-mediated immune suppression. Gut. (2021) 70:330-41. doi: 10.1136/gutjnl-2019-319912

360. Pylayeva-Gupta Y, Das S, Handler JS, Hajdu CH, Coffre M, Koralov $\mathrm{SB}$, et al. IL35-producing b cells promote the development of pancreatic neoplasia. Cancer Discov. (2016) 6:247-. doi: 10.1158/2159-8290.CD-1 5-0843

361. Leng Y, Romero R, Xu Y, Galaz J, Slutsky R, Arenas-Hernandez M, et al. Are $\mathrm{B}$ cells altered in the decidua of women with preterm or term labor? Am J Reprod Immunol. (2019) 81:e13102. doi: 10.1111/aji.13102

362. Slawek A, Lorek D, Kedzierska AE, Chelmonska-Soyta A. Regulatory B cells with IL-35 and IL-10 expression in a normal and abortionprone murine pregnancy model. Am J Reprod Immunol. (2020) 83:e13217. doi: 10.1111/aji.13217

363. Fonseca-Camarillo G, Furuzawa-Carballeda J, Yamamoto-Furusho JK Interleukin 35 (IL-35) and IL-37: intestinal and peripheral expression by $\mathrm{T}$ and $\mathrm{B}$ regulatory cells in patients with Inflammatory Bowel Disease. Cytokine. (2015) 75:389-402. doi: 10.1016/j.cyto.2015.04.009

364. Zhao M, Gu J, Wang Z. B cells in Crohn's patients presented reduced IL-35 expression capacity. Mol Immunol. (2020) 118:12431. doi: 10.1016/j.molimm.2019.12.005

365. Wang S, Qin C. Interleukin 35 rescues regulatory B cell function, but the effect is dysregulated in ulcerative colitis. DNA Cell Biol. (2017) 36:41321. doi: $10.1089 /$ dna.2016.3570

366. Ye Z, Jiang Y, Sun D, Zhong W, Zhao L, Jiang Z. The plasma interleukin (IL)-35 level and frequency of circulating IL-35+ regulatory B cells are decreased in a cohort of Chinese patients with new-onset systemic lupus erythematosus. Sci Rep. (2019) 9:13210. doi: 10.1038/s41598-019-49748-Z

367. Dai YC, Wang WD, Zhang JA, Chen C, Luo HL, Xu H, et al. MTB driven B cells producing IL-35 and secreting high level of IL-10 in the patients with active pulmonary tuberculosis. Mol Immunol. (2019) 112:17581. doi: 10.1016/j.molimm.2019.05.004

368. Tarique M, Saini C, Naqvi RA, Khanna N, Rao DN. Increased IL-35 producing Tregs and CD19+IL-35+ cells are associated with disease progression in leprosy patients. Cytokine. (2017) 91:82-8. doi: 10.1016/j.cyto.2016.12.011

369. Wang K, Liu J, Li J. IL-35-producing B cells in gastric cancer patients. Medicine. (2018) 97:e0710. doi: 10.1097/MD.0000000000010710

370. Choi JK, Dambuza IM, He C, Yu CR, Uche AN, Mattapallil $\mathrm{MJ}$, et al. IL-12p35 inhibits neuroinflammation and ameliorates 
autoimmune encephalomyelitis. Front Immunol. (2017) 8:5. doi: 10.3389/fimmu.2017.01258

371. Guo H, Li B, Wang W, Zhao N, Gao H. Mesenchymal stem cells overexpressing IL-35: a novel immunosuppressive strategy and therapeutic target for inducing transplant tolerance. Stem Cell Res Ther. (2018) 9:254. doi: 10.1186/s13287-018-0988-9

372. Kang M, Choi JK, Jittayasothorn Y, Egwuagu CE. Interleukin 35-producing exosomes suppress neuroinflammation and autoimmune uveitis. Front Immunol. (2020) 11:1051. doi: 10.3389/fimmu.2020.01051

373. Sullivan JA, Tomita Y, Jankowska-Gan E, Lema DA, Arvedson MP, Nair A, et al. Treg-cell-derived IL-35-coated extracellular vesicles promote infectious tolerance. Cell Rep. (2020) 30:1039-51.e5. doi: 10.1016/j.celrep.2019.12.081

374. Sullivan JA, AlAdra DP, Olson BM, McNeel DG, Burlingham WJ. Infectious tolerance as seen with 2020 vision: the role of IL-35 and extracellular vesicles. Front Immunol. (2020) 11:1867. doi: 10.3389/fimmu.2020.01867

375. Grossman WJ, Revell PA, Lu ZH, Johnson H, Bredemeyer AJ, Ley TJ. The orphan granzymes of humans and mice. Curr Opin Immunol. (2003) 15:544-52. doi: 10.1016/S0952-7915(03)00099-2

376. Joeckel LT, Bird PI. Are all granzymes cytotoxic in vivo? Biol Chem. (2014) 395:181-202. doi: 10.1515/hsz-2013-0238

377. Bots M, Medema JP. Granzymes at a glance. J Cell Sci. (2006) 119:50114. doi: $10.1242 /$ jcs. 03239

378. Buzza MS, Bird PI. Extracellular granzymes: current perspectives. Biol Chem. (2006) 387:827-37. doi: 10.1515/BC.2006.106

379. Omoto Y, Yamanaka K, Tokime K, Kitano S, Kakeda M, Akeda T, et al. Granzyme B is a novel interleukin-18 converting enzyme. J Dermatol Sci. (2010) 59:129-35. doi: 10.1016/j.jdermsci.2010.05.004

380. Afonina IS, Cullen SP, Martin SJ. Cytotoxic and non-cytotoxic roles of the CTL/NK protease granzyme B. Immunol Rev. (2010) 235:10516. doi: 10.1111/j.0105-2896.2010.00908.x

381. Boivin WA, Shackleford M, Vanden Hoek A, Zhao H, Hackett TL, Knight DA, et al. Granzyme B cleaves decorin, biglycan and soluble betaglycan, releasing active transforming growth factor- $\beta 1$. PLoS ONE. (2012) 7:e33163. doi: 10.1371/journal.pone.0033163

382. Wieckowski E, Wang GQ, Gastman BR, Goldstein LA, Rabinowich H. Granzyme B-mediated degradation of T-cell receptor $\zeta$ chain. Cancer Res. (2002) 62:4884-9.

383. Gondek DC, Lu L-F, Quezada SA, Sakaguchi S, Noelle RJ. Cutting edge: contact-mediated suppression by CD $4+\mathrm{CD} 25+$ regulatory cells involves a granzyme B-dependent, perforin-independent mechanism. J Immunol. (2005) 174:1783-6. doi: 10.4049/jimmunol.174.4.1783

384. Jahrsdörfer B, Vollmer A, Blackwell SE, Maier J, Sontheimer K, Beyer T, et al. Granzyme B produced by human plasmacytoid dendritic cells suppresses T-cell expansion. Blood. (2010) 115:1156-65. doi: 10.1182/blood-2009-07-235382

385. Lindner S, Dahlke K, Sontheimer K, Hagn M, Kaltenmeier C, Barth TFEE, et al. Interleukin 21-induced granzyme b-expressing b cells infiltrate tumors and regulate $t$ cells. Cancer Res. (2013) 73:246879. doi: 10.1158/0008-5472.CAN-12-3450

386. Xu L, Liu X, Liu H, Zhu L, Zhu H, Zhang J, et al. Impairment of granzyme B-producing regulatory $\mathrm{B}$ cells correlates with exacerbated rheumatoid arthritis. Front Immunol. (2017) 8:768. doi: 10.3389/fimmu.2017.00768

387. Jahrsdörfer B, Blackwell SE, Wooldridge JE, Huang J, Andreski MW, Jacobus LS, et al. B-chronic lymphocytic leukemia cells and other B cells can produce granzyme $\mathrm{B}$ and gain cytotoxic potential after interleukin-21-based activation. Blood. (2006) 108:2712-9. doi: 10.1182/blood-2006-03-014001

388. Kaltenmeier C, Gawanbacht A, Beyer T, Lindner S, Trzaska T, van der Merwe JA, et al. CD4 + T cell-derived IL-21 and deprivation of CD40 signaling favor the in vivo development of granzyme B-expressing regulatory B cells in HIV patients. J Immunol. (2015) 194:3768-77. doi: 10.4049/jimmunol.1402568

389. Bulati M, Buffa S, Martorana A, Candore G, Lio D, Caruso C, et al. Trafficking phenotype and production of granzyme B by double negative B cells (IgG+IgD-CD27-) in the elderly. Exp Gerontol. (2014) 54:1239. doi: 10.1016/j.exger.2013.12.011

390. Chesneau M, Michel L, Dugast E, Chenouard A, Baron D, Pallier A, et al. Tolerant kidney transplant patients produce B cells with regulatory properties. J Am Soc Nephrol. (2015) 26:2588-98. doi: 10.1681/ASN.2014040404
391. Hasan MM, Thompson-Snipes L, Klintmalm G, Demetris AJ, O'Leary J, Oh S, et al. CD24 hi CD38 hi and CD24 hi CD27 + human regulatory B cells display common and distinct functional characteristics. J Immunol. (2019) 203:2110-20. doi: 10.4049/jimmunol.1900488

392. Hagn M, Belz GT, Kallies A, Sutton VR, Thia KY, Tarlinton DM, et al. Activated mouse B cells lack expression of granzyme B. J Immunol. (2012) 188:3886-92. doi: 10.4049/jimmunol.1103285

393. Zhu J, Zeng Y, Dolff S, Bienholz A, Lindemann M, Brinkhoff A, et al. Granzyme B producing B-cells in renal transplant patients. Clin Immunol. (2017) 184:48-53. doi: 10.1016/j.clim.2017.04.016

394. Hagn M, Ebel V, Sontheimer K, Schwesinger E, Lunov O, Beyer T, et al. $\mathrm{CD} 5+\mathrm{B}$ cells from individuals with systemic lupus erythematosus express granzyme B. Eur J Immunol. (2010) 40:2060-9. doi: 10.1002/eji.200940113

395. Cui D, Zhang L, Chen J, Zhu M, Hou L, Chen B, et al. Changes in regulatory $\mathrm{B}$ cells and their relationship with rheumatoid arthritis disease activity. Clin Exp Med. (2015) 15:285-92. doi: 10.1007/s10238-014-0310-9

396. Papp G, Gyimesi E, Szabó K, Zöld É, Zeher M. Increased IL-21 expression induces granzyme B in peripheral $\mathrm{CD} 5+\mathrm{B}$ cells as a potential counterregulatory effect in primary Sjögren's syndrome. Mediators Inflamm. (2016) 2016:1-8. doi: 10.1155/2016/4328372

397. Cupi ML, Sarra M, Marafini I, Monteleone I, Franzè E, Ortenzi A, et al. Plasma cells in the mucosa of patients with inflammatory bowel disease produce granzyme B and possess cytotoxic activities. J Immunol. (2014) 192:6083-91. doi: 10.4049/jimmunol.1302238

398. Arabpour M, Rasolmali R, Talei AR, Mehdipour F, Ghaderi A. Granzyme B production by activated $B$ cells derived from breast cancer-draining lymph nodes. Mol Immunol. (2019) 114:172-8. doi: 10.1016/j.molimm.2019.07.019

399. Zhang Y, Morgan R, Chen C, Cai Y, Clark E, Khan WN, et al. Mammary-tumor-educated b cells acquire lap/tgf- $\beta$ and pd-11 expression and suppress antitumor immune responses. Int Immunol. (2016) 28:42333. doi: 10.1093/intimm/dxw007

400. Brigl M, Brenner MB. CD1: antigen presentation and $\mathrm{T}$ cell function. Annu Rev Immunol. (2004) 22:81790. doi: 10.1146/annurev.immunol.22.012703.104608

401. Salio M, Silk JD, Yvonne Jones E, Cerundolo V. Biology of CD1- and MR1-restricted T cells. Annu Rev Immunol. (2014) 32:323-66. doi: 10.1146/annurev-immunol-032713-120243

402. Naumov YN, Bahjat KS, Gausling R, Abraham R, Exley MA, Koezuka Y, et al. Activation of CD1d-restricted T cells protects NOD mice from developing diabetes by regulating dendritic cell subsets. Proc Natl Acad Sci USA. (2001) 98:13838-43. doi: 10.1073/pnas. 251531798

403. Singh AK, Wilson MT, Hong S, Olivares-Villagómez D, Du C, Stanic $\mathrm{AK}$, et al. Natural killer $\mathrm{T}$ cell activation protects mice against experimental autoimmune encephalomyelitis. J Exp Med. (2001) 194:1801-11. doi: 10.1084/jem.194.12.1801

404. Coppieters K, Van Beneden K, Jacques P, Dewint P, Vervloet A, Vander Cruyssen B, et al. A single early activation of invariant NK T cells confers long-term protection against collagen-induced arthritis in a ligand-specific manner. J Immunol. (2007) 179:2300-9. doi: 10.4049/jimmunol.179.4.2300

405. Roark JH, Park SH, Jayawardena J, Kavita U, Shannon M, Bendelac A. CD1.1 expression by mouse antigen-presenting cells and marginal zone B cells. $J$ Immunol. (1998) 160:3121-7.

406. Leadbetter EA, Brigl M, Illarionov P, Cohen N, Luteran MC, Pillai S, et al. NK T cells provide lipid antigen-specific cognate help for B cells. Proc Natl Acad Sci USA. (2008) 105:8339-44. doi: 10.1073/pnas.08013 75105

407. Barral P, Eckl-Dorna J, Harwood NE, De Santo C, Salio M, Illarionov $\mathrm{P}$, et al. B cell receptor-mediated uptake of CDld-restricted antigen augments antibody responses by recruiting invariant NKT cell help in vivo. Proc Natl Acad Sci USA. (2008) 105:8345-50. doi: 10.1073/pnas.08029 68105

408. Galli G, Nuti S, Tavarini S, Galli-Stampino L, De Lalla C, Casorati G, et al. CD1d-restricted help to B cells by human invariant natural killer $\mathrm{T}$ lymphocytes. J Exp Med. (2003) 197:1051-7. doi: 10.1084/jem.20021616

409. Allan LL, Stax AM, Zheng D-J, Chung BK, Kozak FK, Tan R, et al. CD1d and CD1c expression in human B cells is regulated by activation and retinoic acid receptor signaling. J Immunol. (2011) 186:526172. doi: 10.4049/jimmunol.1003615 
410. Burke F, Stagg AJ, Bedford PA, English N, Knight SC. IL-10-producing B220 + CD11c - APC in mouse spleen. J Immunol. (2004) 173:236272. doi: 10.4049/jimmunol.173.4.2362

411. Chen Y, Li C, Lu Y, Zhuang H, Gu W, Liu B, et al. IL-10Producing CD1dhiCD5+ regulatory $\mathrm{B}$ cells may play a critical role in modulating immune homeostasis in silicosis patients. Front Immunol. (2017) 8:110. doi: 10.3389/fimmu.2017.00110

412. Bosma A, Abdel-Gadir A, Isenberg DA, Jury EC, Mauri C. Lipidantigen presentation by $\mathrm{CD} 1 \mathrm{~d}+\mathrm{B}$ cells is essential for the maintenance of invariant natural killer $\mathrm{T}$ cells. Immunity. (2012) 36:477-90. doi: 10.1016/j.immuni.2012.02.008

413. Mishima $\mathrm{Y}$, Ishihara S, Aziz MM, Oka A, Kusunoki R, Otani A, et al. Decreased production of interleukin-10 and transforming growth factor$\beta$ in Toll-like receptor-activated intestinal B cells in SAMP1/Yit mice. Immunology. (2010) 131:473-87. doi: 10.1111/j.1365-2567.2010.03318.x

414. Oleinika K, Rosser EC, Matei DE, Nistala K, Bosma A, Drozdov I, et al. CD1d-dependent immune suppression mediated by regulatory B cells through modulations of iNKT cells. Nat Commun. (2018) 9:684. doi: 10.1038/s41467-018-02911-y

415. Zeng SG, Ghnewa YG, O'Reilly VP, Lyons VG, Atzberger A, Hogan AE, et al. Human invariant NKT cell subsets differentially promote differentiation, antibody production, and $\mathrm{T}$ cell stimulation by B cells in vitro. J Immunol. (2013) 191:1666-76. doi: 10.4049/jimmunol.1202223

416. Vomhof-DeKrey EE, Yates $\mathrm{J}$, Hägglöf $\mathrm{T}$, Lanthier $\mathrm{P}$, Amiel $\mathrm{E}$, Veerapen N, et al. Cognate interaction with iNKT cells expands IL-10-producing B regulatory cells. Proc Natl Acad Sci USA. (2015) 112:12474-9. doi: 10.1073/pnas.1504790112

417. Tan AHM, Chong WPK, Ng SW, Basri N, Xu S, Lam KP. Aberrant presentation of self-lipids by autoimmune B cells depletes peripheral iNKT cells. Cell Rep. (2014) 9:24-31. doi: 10.1016/j.celrep.2014.08.043

418. Yanagihara Y, Shiozawa K, Takai M, Kyogoku M, Shiozawa S. Natural killer (NK) T cells are significantly decreased in the peripheral blood of patients with rheumatoid arthritis (RA). Clin Exp Immunol. (1999) 118:1316. doi: 10.1046/j.1365-2249.1999.01018.x

419. Kojo S, Adachi Y, Keino H, Taniguchi M, Sumida T. Dysfunction of T cell receptor AV24AJ18+,BV11+ double-negative regulatory natural killer T cells in autoimmune diseases. Arthritis Rheum. (2001) 44:1127-38. doi: 10. 1002/1529-0131(200105)44:5<1127::AID-ANR194>3.0.CO;2-W

420. Green MRJ, Kennell ASM, Larche MJ, Seifert MH, Isenberg DA, Salaman MR. Natural killer $\mathrm{T}$ cells in families of patients with systemic lupus erythematosus: their possible role in regulation of IgG production. Arthritis Rheum. (2007) 56:303-10. doi: 10.1002/art.22326

421. Tudhope SJ, Von Delwig A, Falconer J, Pratt A, Woolridge T, Wilson G, et al. Profound invariant natural killer T-cell deficiency in inflammatory arthritis. Ann Rheum Dis. (2010) 69:1873-9. doi: 10.1136/ard.2009.125849

422. Sharma P, Allison JP. The future of immune checkpoint therapy. Science. (2015) 348:56-61. doi: 10.1126/science.aaa8172

423. Michot JM, Bigenwald C, Champiat S, Collins M, Carbonnel F, Postel-Vinay $\mathrm{S}$, et al. Immune-related adverse events with immune checkpoint blockade: a comprehensive review. Eur J Cancer. (2016) 54:139-48. doi: 10.1016/j.ejca.2015.11.016

424. Paluch C, Santos AM, Anzilotti C, Cornall RJ, Davis SJ. Immune checkpoints as therapeutic targets in autoimmunity. Front Immunol. (2018) 9:2306. doi: 10.3389/fimmu.2018.02306

425. Hirata S, Senju S, Matsuyoshi H, Fukuma D, Uemura Y, Nishimura Y. Prevention of experimental autoimmune encephalomyelitis by transfer of embryonic stem cell-derived dendritic cells expressing myelin oligodendrocyte glycoprotein peptide along with TRAIL or programmed death-1 ligand. I Immunol. (2005) 174:1888-97. doi: 10.4049/jimmunol.174.4.1888

426. Raptopoulou AP, Bertsias G, Makrygiannakis D, Verginis P, Kritikos I, Tzardi $\mathrm{M}$, et al. The programmed death 1/programmed death ligand 1 inhibitory pathway is up-regulated in rheumatoid synovium and regulates peripheral $\mathrm{T}$ cell responses in human and murine arthritis. Arthritis Rheum. (2010) 62:1870-80. doi: 10.1002/art.27500

427. Wang G, Hu P, Yang J, Shen G, Wu X. The effects of PDL-Ig on collagen-induced arthritis. Rheumatol Int. (2011) 31:513-9. doi: 10.1007/s00296-009-1249-0
428. Zhou $\mathrm{H}$, Xiong $\mathrm{L}$, Wang $\mathrm{Y}$, Ding $\mathrm{L}$, $\mathrm{Hu} \mathrm{S}$, Zhao $\mathrm{M}$, et al. Treatment of murine lupus with PD-LIg. Clin Immunol. (2016) 162:1-8. doi: 10.1016/j.clim.2015.10.006

429. Özkaynak E, Wang L, Goodearl A, McDonald K, Qin S, O'Keefe T, et al. Programmed death-1 targeting can promote allograft survival. J Immunol. (2002) 169:6546-53. doi: 10.4049/jimmunol.169.11.6546

430. Totsuka T, Kanai T, Makita S, Fujii R, Nemoto Y, Oshima S, et al. Regulation of murine chronic colitis by $\mathrm{CD} 4+\mathrm{CD} 25$ - programmed death-1+ T cells. Eur J Immunol. (2005) 35:1773-85. doi: 10.1002/eji.200425109

431. Francisco LM, Salinas VH, Brown KE, Vanguri VK, Freeman GJ, Kuchroo VK, et al. PD-L1 regulates the development, maintenance, and function of induced regulatory T cells. J Exp Med. (2009) 206:301529. doi: 10.1084 /jem.20090847

432. Gotot J, Gottschalk C, Leopold S, Knolle PA, Yagita H, Kurts C, et al. Regulatory $\mathrm{T}$ cells use programmed death 1 ligands to directly suppress autoreactive B cells in vivo. Proc Natl Acad Sci USA. (2012) 109:1046873. doi: 10.1073/pnas.1201131109

433. Okamura T, Sumitomo S, Morita K, Iwasaki Y, Inoue M, Nakachi S, et al. TGF- $\beta 3$-expressing CD4+CD25-LAG3 + regulatory T cells control humoral immune responses. Nat Commun. (2015) 6:6329. doi: 10.1038/ncomms 7329

434. Zacca ER, Onofrio LI, Acosta CDV, Ferrero PV, Alonso SM, Ramello MC et al. PD-L1+ regulatory B cells are significantly decreased in rheumatoid arthritis patients and increase after successful treatment. Front Immunol. (2018) 9:2241. doi: 10.3389/fimmu.2018.02241

435. Kubo S, Yamada T, Osawa Y, Ito Y, Narita N, Fujieda S. Cytosinephosphate-guanosine-DNA induces CD274 expression in human B cells and suppresses $\mathrm{T}$ helper type 2 cytokine production in pollen antigen-stimulated CD4-positive cells. Clin Exp Immunol. (2012) 169:1-9. doi: 10.1111/j.1365-2249.2012.04585.x

436. Xiao X, Lao XM, Chen MM, Liu RX, Wei Y, Ouyang FZ, et al. PD-1hi identifi es a novel regulatory b-cell population in human hepatoma that promotes disease progression. Cancer Discov. (2016) 6:54659. doi: 10.1158/2159-8290.CD-15-1408

437. Guan H, Wan Y, Lan J, Wang Q, Wang Z, Li Y, et al. PD-L1 is a critical mediator of regulatory $\mathrm{B}$ cells and $\mathrm{T}$ cells in invasive breast cancer. Sci Rep. (2016) 6:35651. doi: 10.1038/srep35651

438. Wang X, Wang G, Wang Z, Liu B, Han N, Li J, et al. PD-1-expressing B cells suppress $\mathrm{CD} 4+$ and $\mathrm{CD} 8+\mathrm{T}$ cells via PD-1/PD-L1-dependent pathway. Mol Immunol. (2019) 109:20-6. doi: 10.1016/j.molimm.2019.02.009

439. Zhao Y, Shen M, Feng Y, He R, Xu X, Xie Y, et al. Regulatory B cells induced by pancreatic cancer cell-derived interleukin-18 promote immune tolerance via the PD-1/PD-L1 pathway. Oncotarget. (2018) 9:1480314. doi: $10.18632 /$ oncotarget.22976

440. Shen M, Wang J, Yu W, Zhang C, Liu M, Wang K, et al. A novel MDSCinduced PD-1-PD-L1+B-cell subset in breast tumor microenvironment possesses immuno-suppressive properties. Oncoimmunology. (2018) 7:e1413520. doi: 10.1080/2162402X.2017.1413520

441. Tang A, Dadaglio G, Oberkampf M, Di Carlo S, Peduto L, Laubreton D, et al. B cells promote tumor progression in a mouse model of HPV-mediated cervical cancer. Int J Cancer. (2016) 139:1358-71. doi: 10.1002/ijc.30169

442. Shalapour S, Lin XJ, Bastian IN, Brain J, Burt AD, Aksenov AA, et al. Inflammation-induced IgA+ cells dismantle anti-liver cancer immunity. Nature. (2017) 551:340-5. doi: 10.1038/nature24302

443. Bodhankar S, Vandenbark AA, Offner H. Oestrogen treatment of experimental autoimmune encephalomyelitis requires $17 \beta$-oestradiolreceptor-positive $\mathrm{B}$ cells that up-regulate $\mathrm{PD}-1$ on $\mathrm{CD} 4+$ Foxp3+ regulatory T cells. Immunology. (2012) 137:282-93. doi: 10.1111/imm.12013

444. Bodhankar S, Galipeau D, Vandenbark AA, Offner H. PD-1 Interaction with PD-L1 but not PD-L2 on B-cells mediates protective effects of estrogen against EAE. J Clin Cell Immunol. (2013) 4:143. doi: $10.4172 / 2155-9899.1000143$

445. Bodhankar S, Wang C, Vandenbark AA, Offner H. Estrogen-induced protection against experimental autoimmune encephalomyelitis is abrogated in the absence of B cells. Eur J Immunol. (2011) 41:1165-75. doi: 10.1002/eji.201040992

446. Khan AR, Hams E, Floudas A, Sparwasser T, Weaver CT, Fallon PG. PD-L1hi B cells are critical regulators of humoral immunity. Nat Commun. (2015) 6:5997. doi: 10.1038/ncomms6997 
447. Liu M-F, Weng C-T, Weng M-Y. Variable increased expression of program death-1 and program death-1 ligands on peripheral mononuclear cells is not impaired in patients with systemic lupus erythematosus. J Biomed Biotechnol. (2009) 2009:1-6. doi: 10.1155/2009/406136

448. Kim Y, Kim G, Shin H-J, Hyun J-W, Kim S-H, Lee E, et al. Restoration of regulatory B cell deficiency following alemtuzumab therapy in patients with relapsing multiple sclerosis. J Neuroinflammation. (2018) 15:300. doi: 10.1186/s12974-018-1334-y

449. Stefanski AL, Wiedemann A, Reiter K, Hiepe F, Lino AC, Dörner T. Enhanced programmed death 1 and diminished programmed death ligand 1 up-regulation capacity of post-activated lupus B cells. Arthritis Rheumatol. (2019) 71:1539-44. doi: 10.1002/art.40897

450. Floudas A, Neto N, Marzaioli V, Murray K, Moran B, Monaghan MG, et al. Pathogenic, glycolytic PD-1+ B cells accumulate in the hypoxic RA joint. JCI Insight. (2020) 5:e139032. doi: 10.1172/jci.insight.139032

451. Sun C, Mezzadra R, Schumacher TN. Regulation and function of the PD-L1 checkpoint. Immunity. (2018) 48:434-52. doi: 10.1016/j.immuni.2018.03.014

452. Kawamoto S, Tran TH, Maruya M, Suzuki K, Doi Y, Tsutsui Y, et al. The inhibitory receptor $\mathrm{PD}-1$ regulates IgA selection and bacterial composition in the gut. Science. (2012) 336:485-9. doi: 10.1126/science.1217718

453. Hams E, McCarron MJ, Amu S, Yagita H, Azuma M, Chen L, et al. Blockade of B7-H1 (programmed death ligand 1) enhances humoral immunity by positively regulating the generation of $\mathrm{T}$ follicular helper cells. J Immunol. (2011) 186:5648-55. doi: 10.4049/jimmunol.1003161

454. Good-Jacobson KL, Szumilas CG, Chen L, Sharpe AH, Tomayko MM, Shlomchik MJ. PD-1 regulates germinal center B cell survival and the formation and affinity of long-lived plasma cells. Nat Immunol. (2010) 11:535-42. doi: 10.1038/ni.1877

455. Cubas RA, Mudd JC, Savoye AL, Perreau M, Van Grevenynghe J, Metcalf T, et al. Inadequate $\mathrm{T}$ follicular cell help impairs $\mathrm{B}$ cell immunity during HIV infection. Nat Med. (2013) 19:494-9. doi: 10.1038/nm.3109

456. Said SS, Barut GT, Mansur N, Korkmaz A, Sayi-Yazgan A. Bacterially activated B-cells drive $\mathrm{T}$ cell differentiation towards Tr1 through PD-1/PD-L1 expression. Mol Immunol. (2018) 96:48-60. doi: 10.1016/j.molimm.2018.02.010

457. Gassen RB, Fazolo T, Nascimento de Freitas D, Borges TJ, Lima K, Antunes GL, et al. IL-21 treatment recovers follicular helper T cells and neutralizing antibody production in respiratory syncytial virus infection. Immunol Cell Biol. (2021) 99:309-22. doi: 10.1111/imcb.12418

458. Tretter T, Venigalla RKC, Eckstein V, Saffrich R, Sertel S, Ho AD, et al. Induction of CD4+ T-cell anergy and apoptosis by activated human B cells. Blood. (2008) 112:4555-64. doi: 10.1182/blood-2008-02-140087

459. Siegel RM, Chan FKM, Chun HJ, Lenardo MJ. The multifaceted role of Fas signaling in immune cell homeostasis and autoimmunity. Nat Immunol. (2000) 1:469-74. doi: 10.1038/82712

460. Mabrouk I, Buart S, Hasmim M, Michiels C, Connault E, Opolon P, et al. Prevention of autoimmunity and control of recall response to exogenous antigen by fas death receptor ligand expression on T cells. Immunity. (2008) 29:922-33. doi: 10.1016/j.immuni.2008.10.007

461. Hahne M, Renno T, Schroeter M, Irmler M, French L, Bornand T, et al. Activated B cells express functional Fas ligand. Eur J Immunol. (1996) 26:721-4. doi: 10.1002/eji.1830260332

462. Kondo E, Yoshino T, Nishiuchi R, Sakuma I, Nishizaki K, Kayagaki $\mathrm{N}$, et al. Expression of Fas ligand mRNA in germinal centres of the human tonsil. J Pathol. (1997) 183:75-9. doi: 10.1002/(SICI)10969896(199709)183:1<75::AID-PATH1084>3.0.CO;2-4

463. Sträter J, Mariani SM, Walczak H, Rücker FG, Leithäuser F, Krammer PH, et al. CD95 ligand (CD95L) in normal human lymphoid tissues: a subset of plasma cells are prominent producers of CD95L. Am J Pathol. (1999) 154:193-201. doi: 10.1016/S0002-9440(10)65265-0

464. Nilsson $\mathrm{N}$, Ingvarsson S, Borrebaeck CAK. Immature B cells in bone marrow express Fas/FasL. Scand J Immunol. (2000) 51:27984. doi: 10.1046/j.1365-3083.2000.00701.x

465. Nagafuchi H, Wakisaka S, Takeba Y, Takeno M, Sakane T, Suzuki N. Aberrant expression of Fas ligand on anti-DNA autoantibody secreting B lymphocytes in patients with systemic lupus erythematosus: "Immune privilege"-like state of the autoreactive B cells. Clin Exp Rheumatol. (2002) 20:625-31.
466. Bonardelle D, Benihoud K, Kiger N, Bobé P. B lymphocytes mediate Fasdependent cytotoxicity in MRL/ lpr mice. J Leukoc Biol. (2005) 78:10529. doi: 10.1189/jlb.0904536

467. Saxena A, Yagita H, Donner TW, Hamad ARA. Expansion of FasLexpressing CD5+ B cells in type 1 diabetes patients. Front Immunol. (2017) 8:402. doi: 10.3389/fimmu.2017.00402

468. Tian J, Zekzer D, Hanssen L, Lu Y, Olcott A, Kaufman DL. Lipopolysaccharide-activated B cells down-regulate Th1 immunity and prevent autoimmune diabetes in nonobese diabetic mice. J Immunol. (2001) 167:1081-9. doi: 10.4049/jimmunol.167.2.1081

469. Lundy SK, Lerman SP, Boros DL. Soluble egg antigen-stimulated T helper lymphocyte apoptosis and evidence for cell death mediated by FasL $+\mathrm{T}$ and B cells during murine Schistosoma mansoni infection. Infect Immun. (2001) 69:271-80. doi: 10.1128/IAI.69.1.271-280.2001

470. Lundy SK, Boros DL. Fas ligand-expressing B-1a lymphocytes mediate CD4+-T-cell apoptosis during schistosomal infection: induction by interleukin 4 (IL-4) and IL-10. Infect Immun. (2002) 70:812-9. doi: 10.1128/IAI.70.2.812-819.2002

471. Lundy SK, Fox DA. Reduced Fas ligand-expressing splenic CD5+ B lymphocytes in severe collagen-induced arthritis. Arthritis Res Ther. (2009) 11:R128. doi: 10.1186/ar2795

472. Klinker MW, Reed TJ, Fox DA, Lundy SK. Interleukin-5 supports the expansion of Fas ligand-expressing killer B cells that induce antigen-specific apoptosis of CD4+ T cells and secrete interleukin-10. PLoS ONE. (2013) 8:e70131. doi: 10.1371/journal.pone.0070131

473. Wang K, Tao L, Su J, Zhang Y, Zou B, Wang Y, et al. TLR4 supports the expansion of FasL $+\mathrm{CD} 5+\mathrm{CD} 1 \mathrm{dhi}$ regulatory B cells, which decreases in contact hypersensitivity. Mol Immunol. (2017) 87:18899. doi: 10.1016/j.molimm.2017.04.016

474. Montandon R, Korniotis S, Layseca-Espinosa E, Gras C, Megret J, Ezine $\mathrm{S}$, et al. Innate pro-B-cell progenitors protect against type 1 diabetes by regulating autoimmune effector T cells. Proc Natl Acad Sci USA. (2013) 110:E2199-208. doi: 10.1073/pnas.1222446110

475. Tanner JE, Alfieri C. Epstein-barr virus induces Fas (CD95) in T cells and fas ligand in B cells leading to T-cell apoptosis. Blood. (1999) 94:343947. doi: 10.1182/blood.V94.10.3439.422k23 34393447

476. Samuelsson A, Sönnerborg A, Heuts N, Cöster J, Chiodi F. Progressive B cell apoptosis and expression of Fas ligand during human immunodeficiency virus type 1 infection. AIDS Res Hum Retroviruses. (1997) 13:10318. doi: 10.1089/aid.1997.13.1031

477. Mishra R, Panda SK, Sahoo PK, Bal MS, Satapathy AK. Increased Fas ligand expression of peripheral B-1 cells correlated with CD4 + T-cell apoptosis in filarial-infected patients. Parasite Immunol. (2017) 39:e12421. doi: 10.1111/pim.12421

478. Rich RF, Cook WJ, Green WR. Spontaneous in vivo retrovirus-infected T and B cells, but not dendritic cells, mediate antigen-specific Fas ligand/Fasdependent apoptosis of anti-retroviral CTL. Virology. (2006) 346:287300. doi: 10.1016/j.virol.2005.10.009

479. Eiza N, Zuckerman E, Carlebach M, Rainis T, Goldberg Y, Vadasz Z. Increased killer B cells in chronic HCV infection may lead to autoimmunity and increased viral load. Clin Exp Immunol. (2018) 193:18393. doi: 10.1111/cei.13139

480. Acosta Rodriguez E V. Interleukin-4 biases differentiation of B cells from Trypanosoma cruzi-infected mice and restrains their fratricide: role of Fas ligand down-regulation and MHC class II-transactivator up-regulation. J Leukoc Biol. (2003) 73:127-36. doi: 10.1189/jlb.0702353

481. Zuñiga E, Motran CC, Montes CL, Yagita H, Gruppi A. Trypanosoma cruzi infection selectively renders parasite-specific IgG + B lymphocytes susceptible to Fas/Fas ligand-mediated fratricide. I Immunol. (2002) 168:3965-73. doi: 10.4049/jimmunol.168.8.3965

482. Zhang H, Wang Z, Liu R, Qian T, Liu J, Wang L, et al. Reactive oxygen species stimulated pulmonary epithelial cells mediate the alveolar recruitment of FasL+ killer B cells in LPS-induced acute lung injuries. J Leukoc Biol. (2018) 104:1187-98. doi: 10.1002/JLB.3A0218-075R

483. Tao H, Lu L, Xia Y, Dai F, Wang Y, Bao Y, et al. Antitumor effector B cells directly kill tumor cells via the Fas/FasL pathway and are regulated by IL-10. Eur J Immunol. (2015) 45:999-1009. doi: 10.1002/eji.2014 44625 
484. Lu L, Weng C, Mao H, Fang X, Liu X, Wu Y, et al. IL-17A promotes migration and tumor killing capability of B cells in esophageal squamous cell carcinoma. Oncotarget. (2016) 7:21853-64. doi: 10.18632/oncotarget.7869

485. Lopez-Cepero M, Garcia-Sanz JA, Herbert L, Riley R, Handel ME, Podack ER, et al. Soluble and membrane-bound TNF- $\alpha$ are involved in the cytotoxic activity of B cells from tumor-bearing mice against tumor targets. J Immunol. (1994) 152:3333-41.

486. Ray A, Basu S, Williams CB, Salzman NH, Dittel BN. A novel IL-10independent regulatory role for B cells in suppressing autoimmunity by maintenance of regulatory T cells via GITR Ligand. J Immunol. (2012) 188:3188-98. doi: 10.4049/jimmunol.1103354

487. Mariani SM, Krammer PH. Surface expression of TRAIL/Apo-2 ligand in activated mouse T and B cells. Eur J Immunol. (1998) 28:1492-8. doi: 10. 1002/(SICI)1521-4141(199805)28:05<1492::AID-IMMU1492>3.0.CO;2-X

488. Kemp TJ, Moore JM, Griffith TS. Human B cells express functional TRAIL/Apo-2 ligand after CpG-containing oligodeoxynucleotide stimulation. J Immunol. (2004) 173:892-9. doi: 10.4049/jimmunol.173.2.892

489. Hu F, Liu H, Liu X, Zhang X, Xu L, Zhu H, et al. Pathogenic conversion of regulatory $\mathrm{B} 10$ cells into osteoclast-priming cells in rheumatoid arthritis. $J$ Autoimmun. (2017) 76:53-62. doi: 10.1016/j.jaut.2016.09.002

490. Meyers J, Sabatos CA, Chakravarti S, Kuchroo VK. The \{TIM\} gene family regulates autoimmune and allergic diseases. Trends Mol Med. (2005) 11:3629. doi: 10.1016/j.molmed.2005.06.008

491. Freeman GJ, Casasnovas JM, Umetsu DT, Dekruyff RH. TIM genes: a family of cell surface phosphatidylserine receptors that regulate innate and adaptive immunity. Immunol Rev. (2010) 235:172-89. doi: 10.1111/j.0105-2896.2010.00903.x

492. Rennert PD. Novel roles for TIM-1 in immunity and infection. Immunol Lett. (2011) 141:28-35. doi: 10.1016/j.imlet.2011.08.003

493. Meyers JH, Chakravarti S, Schlesinger D, Illes Z, Waldner H, Umetsu SE, et al. TIM-4 is the ligand for TIM-1, and the TIM-1-TIM-4 interaction regulates T cell proliferation. Nat Immunol. (2005) 6:455-64. doi: 10.1038/ni1185

494. Umetsu SE, Lee WL, McIntire JJ, Downey L, Sanjanwala B, Akbari O, et al. TIM-1 induces T cell activation and inhibits the development of peripheral tolerance. Nat Immunol. (2005) 6:447-54. doi: 10.1038/ni1186

495. Xiao S, Zhu B, Jin H, Zhu C, Umetsu DT, Dekruyff RH, et al. Tim-1 stimulation of dendritic cells regulates the balance between effector and regulatory T cells. Eur J Immunol. (2011) 41:153949. doi: 10.1002/eji.201040993

496. Gielen AW, Lobell A, Lidman O, Khademi M, Olsson T, Piehl F. Expression of $\mathrm{T}$ cell immunoglobulin- and mucin-domain-containing molecules1 and-3 (TIM-1 and-3) in the rat nervous and immune systems. $J$ Neuroimmunol. (2005) 164:93-104. doi: 10.1016/j.jneuroim.2005.04.004

497. Wong SH, Barlow JL, Nabarro S, Fallon PG, McKenzie ANJ. Tim-1 is induced on germinal centre B cells through B-cell receptor signalling but is not essential for the germinal centre response. Immunology. (2010) 131:7788. doi: 10.1111/j.1365-2567.2010.03276.x

498. Lee KM, Kim JI, Stott R, Soohoo J, O’Connor MR, Yeh H, et al. AntiCD45RB/anti-TIM-1-induced tolerance requires regulatory B cells. Am J Transplant. (2012) 12:2072-8. doi: 10.1111/j.1600-6143.2012.04055.x

499. Li S, Li X, Yang M, Wei L, Deng S, Zhao G. Identification of the subsets of IL-10-producing regulatory B cells in the course of tolerance induction and maintenance in islet allotransplantation. Transplant Proc. (2018) 50:39005. doi: 10.1016/j.transproceed.2018.04.065

500. Moreau A, Blair PA, Chai JG, Ratnasothy K, Stolarczyk E, Alhabbab R, et al. Transitional-2 B cells acquire regulatory function during tolerance induction and contribute to allograft survival. Eur J Immunol. (2015) 45:84353. doi: 10.1002/eji.201445082

501. Xu Y, Wu K, Han S, Ding S, Lu G, Lin Z, et al. Astilbin combined with lipopolysaccharide induces IL-10-producing regulatory B cells via the STAT3 signalling pathway. Biomed Pharmacother. (2020) 129:110450. doi: 10.1016/j.biopha.2020.110450

502. Ding Q, Mohib K, Kuchroo VK, Rothstein DM. TIM-4 identifies IFN- $\gamma$-expressing proinflammatory B effector 1 cells that promote tumor and allograft rejection. J Immunol. (2017) 199:2585-95. doi: 10.4049/jimmunol.1602107

503. Miles K, Heaney J, Sibinska Z, Salter D, Savill J, Gray D, et al. A tolerogenic role for Toll-like receptor 9 is revealed by B-cell interaction with DNA complexes expressed on apoptotic cells. Proc Natl Acad Sci USA. (2012) 109:887-92. doi: 10.1073/pnas.1109173109

504. Yeung MY, Ding Q, Brooks CR, Xiao S, Workman CJ, Vignali DAA, et al. TIM-1 signaling is required for maintenance and induction of regulatory b cells. Am J Transplant. (2015) 15:942-53. doi: 10.1111/ajt.13087

505. Audo R, Hua C, Hahne M, Combe B, Morel J, Daien CI. Phosphatidylserine outer layer translocation is implicated in IL10 secretion by human regulatory B cells. PLoS ONE. (2017) 12:e0169755. doi: 10.1371/journal.pone.0169755

506. Xiao S, Brooks CR, Zhu C, Wu C, Sweere JM, Petecka S, et al. Defect in regulatory $\mathrm{B}$-cell function and development of systemic autoimmunity in $\mathrm{T}$ cell Ig mucin 1 (Tim-1) mucin domain-mutant mice. Proc Natl Acad Sci USA. (2012) 109:12105-10. doi: 10.1073/pnas.1120914109

507. Xiao S, Bod L, Pochet N, Kota SB, Hu D, Madi A, et al. Checkpoint receptor TIGIT expressed on Tim-1+ B cells regulates tissue inflammation. Cell Rep. (2020) 32:107892. doi: 10.1016/j.celrep.2020.107892

508. Xiao S, Brooks CR, Sobel RA, Kuchroo VK. Tim-1 is essential for induction and maintenance of IL-10 in regulatory B cells and their regulation of tissue inflammation. J Immunol. (2015) 194:16028. doi: 10.4049/jimmunol.1402632

509. Lee KM, Yeh H, Zhao G, Wei L, O'Connor M, Stott RT, et al. B-Cell depletion improves islet allograft survival with anti-CD45RB. Cell Transplant. (2014) 23:51-8. doi: 10.3727/096368912X658962

510. Gu XL, He H, Lin L, Luo GX, Wen YF, Xiang DC, et al. Tim-1+ B cells suppress $\mathrm{T}$ cell interferon-gamma production and promote Foxp3 expression, but have impaired regulatory function in coronary artery disease. APMIS. (2017) 125:872-9. doi: 10.1111/apm.12729

511. Gutiérrez C, Lopez-Abente J, Pérez-Fernández V, Prieto-Sánchez A, Correa-Rocha R, Moreno-Guillen S, et al. Analysis of the dysregulation between regulatory $\mathrm{B}$ and $\mathrm{T}$ cells (Breg and Treg) in human immunodeficiency virus (HIV)-infected patients. PLoS ONE. (2019) 14:e0213744. doi: 10.1371/journal.pone.0213744

512. Xue H, Lin F, Tan H, Zhu Z-Q, Zhang Z-Y, Zhao L. Overrepresentation of IL-10-expressing $\mathrm{B}$ cells suppresses cytotoxic CD4+ $\mathrm{T}$ cell activity in HBV-induced hepatocellular carcinoma. PLoS ONE. (2016) 11:e0154815. doi: 10.1371/journal.pone.0154815

513. Ye L, Zhang Q, Cheng Y, Chen X, Wang G, Shi M, et al. Tumor-derived exosomal HMGB1 fosters hepatocellular carcinoma immune evasion by promoting TIM-1+ regulatory B cell expansion. J Immunother Cancer. (2018) 6:145. doi: 10.1186/s40425-018-0451-6

514. Ma L, Liu B, Jiang Z, Jiang Y. Reduced numbers of regulatory $\mathrm{B}$ cells are negatively correlated with disease activity in patients with new-onset rheumatoid arthritis. Clin Rheumatol. (2014) 33:18795. doi: 10.1007/s10067-013-2359-3

515. Aravena O, Ferrier A, Menon M, Mauri C, Aguillón JC, Soto L, et al. TIM-1 defines a human regulatory $\mathrm{B}$ cell population that is altered in frequency and function in systemic sclerosis patients. Arthritis Res Ther. (2017) 19:8. doi: 10.1186/s13075-016-1213-9

516. Zhu G, Liu Y, Zhang W, Huang Y, Li K. CD27 + TIM-1 + memory B cells promoted the development of Foxp3 + Tregs and were associated with better survival in acute respiratory distress syndrome. Immunol Res. (2018) 66:281-7. doi: 10.1007/s12026-017-8983-2

517. Sizing ID, Bailly V, McCoon P, Chang W, Rao S, Pablo L, et al. Epitopedependent effect of anti-murine TIM-1 monoclonal antibodies on $\mathrm{T}$ cell activity and lung immune responses. J Immunol. (2007) 178:224961. doi: 10.4049/jimmunol.178.4.2249

518. Rodriguez-Manzanet R, Meyers JH, Balasubramanian S, Slavik J, Kassam N, Dardalhon V, et al. TIM-4 expressed on APCs induces T cell expansion and survival. J Immunol. (2008) 180:4706-13. doi: 10.4049/jimmunol.180.7.4706

519. Kobayashi N, Karisola P, Peña-Cruz V, Dorfman DM, Jinushi M, Umetsu SE, et al. TIM-1 and TIM-4 glycoproteins bind phosphatidylserine and mediate uptake of apoptotic cells. Immunity. (2007) 27:92740. doi: 10.1016/j.immuni.2007.11.011

520. Santiago C, Ballesteros A, Tami C, Martínez-Muñoz L, Kaplan GG, Casasnovas JM. Structures of T cell immunoglobulin mucin receptors 1 and 2 reveal mechanisms for regulation of immune responses by the TIM receptor family. Immunity. (2007) 26:299-310. doi: 10.1016/j.immuni.2007. 01.014 
521. Miyanishi M, Tada K, Koike M, Uchiyama Y, Kitamura T, Nagata S. Identification of Tim4 as a phosphatidylserine receptor. Nature. (2007) 450:435-9. doi: 10.1038/nature06307

Conflict of Interest: The authors declare that the research was conducted in the absence of any commercial or financial relationships that could be construed as a potential conflict of interest.
Copyright $\odot 2021$ Catalán, Mansilla, Ferrier, Soto, Oleinika, Aguillón and Aravena. This is an open-access article distributed under the terms of the Creative Commons Attribution License (CC BY). The use, distribution or reproduction in other forums is permitted, provided the original author(s) and the copyright owner(s) are credited and that the original publication in this journal is cited, in accordance with accepted academic practice. No use, distribution or reproduction is permitted which does not comply with these terms. 